\title{
Patient-initiated appointment systems for adults with chronic conditions in secondary care (Review)
}

Whear R, Thompson-Coon J, Rogers M, Abbott RA, Anderson L, Ukoumunne O, Matthews J, Goodwin VA, Briscoe S, Perry M, Stein K

Whear R, Thompson-Coon J, Rogers M, Abbott RA, Anderson L, Ukoumunne O, Matthews J, Goodwin VA, Briscoe S, Perry M, Stein $\mathrm{K}$.

Patient-initiated appointment systems for adults with chronic conditions in secondary care.

Cochrane Database of Systematic Reviews 2020, Issue 4. Art. No.: CD010763.

DOI: 10.1002/14651858.CD010763.pub2. 
TABLE OF CONTENTS

HEADER

ABSTRACT

PLAIN LANGUAGE SUMMARY

SUMMARY OF FINDINGS

BACKGROUND

OBJECTIVES

METHODS

RESULTS

Figure 1.

Figure 2.

Figure 3.

Figure 4.

Figure 5.

Figure 6.

DISCUSSION

AUTHORS' CONCLUSIONS

ACKNOWLEDGEMENTS

REFERENCES

CHARACTERISTICS OF STUDIES

DATA AND ANALYSES

Analysis 1.1. Comparison 1 Patient-initiated appointment systems versus consultant-led appointment systems, Outcome 1 Patient outcomes: anxiety (HADS lower score = better 0-21) (12-24 months).

Analysis 1.2. Comparison 1 Patient-initiated appointment systems versus consultant-led appointment systems, Outcome 2 Patient outcomes: depression (HADS lower score = better 0-21) (9-24months).

Analysis 1.3. Comparison 1 Patient-initiated appointment systems versus consultant-led appointment systems, Outcome 3 Patient outcomes: quality of life (12-18 months).

Analysis 1.4. Comparison 1 Patient-initiated appointment systems versus consultant-led appointment systems, Outcome 4 Rheumatoid arthritis: disease activity (VAS and DAS 12-24 months).

Analysis 1.5. Comparison 1 Patient-initiated appointment systems versus consultant-led appointment systems, Outcome 5 Rheumatoid arthritis: self-efficacy (ASES 12-24 months).

Analysis 1.6. Comparison 1 Patient-initiated appointment systems versus consultant-led appointment systems, Outcome 6 Rheumatoid arthritis: pain (VAS 12-24 months).

Analysis 1.7. Comparison 1 Patient-initiated appointment systems versus consultant-led appointment systems, Outcome 7 Rheumatoid arthritis: disability (HAQ 12-24 months).

Analysis 1.8. Comparison 1 Patient-initiated appointment systems versus consultant-led appointment systems, Outcome 8 Rheumatoid arthritis: patient satisfaction.

Analysis 1.9. Comparison 1 Patient-initiated appointment systems versus consultant-led appointment systems, Outcome 9 Service utilisation (contacts).

Analysis 1.10. Comparison 1 Patient-initiated appointment systems versus consultant-led appointment systems, Outcome 10 Service utilisation (costs).

Analysis 1.11. Comparison 1 Patient-initiated appointment systems versus consultant-led appointment systems, Outcome 11 Missed appointments.

Analysis 1.12. Comparison 1 Patient-initiated appointment systems versus consultant-led appointment systems, Outcome 12 Adverse event: relapses (12-60 months).

Analysis 1.13. Comparison 1 Patient-initiated appointment systems versus consultant-led appointment systems, Outcome 13 Patient satisfaction.

Analysis 1.14. Comparison 1 Patient-initiated appointment systems versus consultant-led appointment systems, Outcome 14 Chronic obstructive pulmonary disease: other outcomes.

Analysis 1.15. Comparison 1 Patient-initiated appointment systems versus consultant-led appointment systems, Outcome 15 Cancer: other outcomes.

Analysis 1.16. Comparison 1 Patient-initiated appointment systems versus consultant-led appointment systems, Outcome 16 Inflammatory bowel disease: other outcomes.

Analysis 1.17. Comparison 1 Patient-initiated appointment systems versus consultant-led appointment systems, Outcome 17 Psoriasis: other outcomes. 
Analysis 1.18. Comparison 1 Patient-initiated appointment systems versus consultant-led appointment systems, Outcome 18 Rheumatoid arthritis: other outcomes.

Analysis 1.19. Comparison 1 Patient-initiated appointment systems versus consultant-led appointment systems, Outcome 19 Asthma: other outcomes.

APPENDICES 
[Intervention Review]

\section{Patient-initiated appointment systems for adults with chronic conditions in secondary care}

Rebecca Whear ${ }^{1}$, Joanna Thompson-Coon ${ }^{1}$, Morwenna Rogers ${ }^{2}$, Rebecca A Abbott ${ }^{1}$, Lindsey Anderson ${ }^{3}$, Obioha Ukoumunne ${ }^{1}$, Justin Matthews ${ }^{2}$, Victoria A Goodwin ${ }^{1}$, Simon Briscoe ${ }^{1}$, Mark Perry ${ }^{4}$, Ken Stein 5

1NIHR CLAHRC South West Peninsula (PenCLAHRC), University of Exeter Medical School, Exeter, UK. 2NIHR PenCLAHRC, Institute of Health Research, University of Exeter Medical School, Exeter, UK. 3Institute of Health Research, University of Exeter Medical School, Exeter, UK. ${ }^{4}$ Rheumatology, Derriford Hospital, Plymouth, UK. ${ }^{5}$ Peninsula Technology Assessment Group (PenTAG), University of Exeter Medical School, University of Exeter, Exeter, UK

Contact address: Rebecca Whear, NIHR CLAHRC South West Peninsula (PenCLAHRC), University of Exeter Medical School, St Luke's Campus, University of Exeter, Exeter, Devon, EX12LU, UK. R.S.Whear@exeter.ac.uk.

Editorial group: Cochrane Effective Practice and Organisation of Care Group.

Publication status and date: New, published in Issue 4, 2020.

Citation: Whear R, Thompson-Coon J, Rogers M, Abbott RA, Anderson L, Ukoumunne O, Matthews J, Goodwin VA, Briscoe S, Perry M, Stein K. Patient-initiated appointment systems for adults with chronic conditions in secondary care. Cochrane Database of Systematic Reviews 2020, Issue 4. Art. No.: CD010763. DOI: 10.1002/14651858.CD010763.pub2.

Copyright @ 2020 The Cochrane Collaboration. Published by John Wiley \& Sons, Ltd.

\section{A B S T R A C T}

\section{Background}

Missed hospital outpatient appointments is a commonly reported problem in healthcare services around the world; for example, they cost the National Health Service (NHS) in the UK millions of pounds every year and can cause operation and scheduling difficulties worldwide. In 2002, the World Health Organization (WHO) published a report highlighting the need for a model of care that more readily meets the needs of people with chronic conditions. Patient-initiated appointment systems may be able to meet this need at the same time as improving the efficiency of hospital appointments.

\section{Objectives}

To assess the effects of patient-initiated appointment systems compared with consultant-led appointment systems for people with chronic or recurrent conditions managed in secondary care.

\section{Search methods}

We searched the Cochrane Central Register of Controlled Trials (CENTRAL), MEDLINE, Embase, and six other databases. We contacted authors of identified studies and conducted backwards and forwards citation searching. We searched for current/ongoing research in two trial registers. Searches were run on 13 March 2019.

\section{Selection criteria}

We included randomised trials, published and unpublished in any language that compared the use of patient-initiated appointment systems to consultant-led appointment systems for adults with chronic or recurrent conditions managed in secondary care if they reported one or more of the following outcomes: physical measures of health status or disease activity (including harms), quality of life, service utilisation or cost, adverse effects, patient or clinician satisfaction, or failures of the 'system'.

\section{Data collection and analysis}

Two review authors independently screened all references at title/abstract stage and full-text stage using prespecified inclusion criteria. We resolved disagreements though discussion. Two review authors independently completed data extraction for all included studies. We discussed and resolved discrepancies with a third review author. Where needed, we contacted authors of included papers to provide more 
information. Two review authors independently assessed the risk of bias using the Cochrane Effective Practice and Organisation of Care 'Risk of bias' tool, resolving any discrepancies with a third review author. Two review authors independently assessed the certainty of the evidence using GRADE.

\section{Main results}

The 17 included randomised trials (3854 participants; mean age 41 to 76 years; follow-up 12 to 72 months) covered six broad health conditions: cancer, rheumatoid arthritis, asthma, chronic obstructive pulmonary disease, psoriasis and inflammatory bowel disease. The certainty of the evidence using GRADE ratings was mainly low to very low. The results suggest that patient-initiated clinics may make little or no difference to anxiety (odds ratio (OR) 0.87 , 95\% confidence interval (CI) 0.68 to 1.12 ; 5 studies, 1019 participants; lowcertainty evidence) or depression (OR $0.7995 \% \mathrm{Cl} 0.51$ to 1.23 ; 6 studies, 1835 participants; low-certainty evidence) compared to the consultant-led appointment system. The results also suggest that patient-initiated clinics may make little or no difference to quality of life (standardised mean difference (SMD) $0.12,95 \% \mathrm{Cl} 0.00$ to $0.25 ; 7$ studies, 1486 participants; low-certainty evidence) compared to the consultant-led appointment system. Results for service utilisation (contacts) suggest there may be little or no difference in service utilisation in terms of contacts between the patient-initiated and consultant-led appointment groups; however, the effect is not certain as the rate ratio ranged from 0.68 to 3.83 across the studies (median rate ratio 1.11 , interquartile (IQR) 0.93 to $1.37 ; 15$ studies, 3348 participants; low-certainty evidence). It is uncertain if service utilisation (costs) are reduced in the patient-initiated compared to the consultant-led appointment groups (8 studies, 2235 participants; very low-certainty evidence). The results suggest that adverse events such as relapses in some conditions (inflammatory bowel disease and cancer) may have little or no reduction in the patient-initiated appointment group in comparison with the consultant-led appointment group ( $\mathrm{MD}-0.20,95 \% \mathrm{Cl}-0.54$ to 0.14 ; 3 studies, 888 participants; low-certainty evidence). The results are unclear about any differences the intervention may make to patient satisfaction (SMD $0.05,95 \%$ $\mathrm{Cl}-0.41$ to $0.52 ; 2$ studies, 375 participants) because the certainty of the evidence is low, as each study used different questions to collect their data at different time points and across different health conditions. Some areas of risk of bias across all the included studies was consistently high (i.e. for blinding of participants and personnel and blinding of outcome assessment, other areas were largely of low risk of bias or were affected by poor reporting making the assessment unclear).

\section{Authors' conclusions}

Patient-initiated appointment systems may have little or no effect on patient anxiety, depression and quality of life compared to consultantled appointment systems. Other aspects of disease status and experience also appear to show little or no difference between patientinitiated and consultant-led appointment systems. Patient-initiated appointment systems may have little or no effect on service utilisation in terms of service contact and there is uncertainty about costs compared to consultant-led appointment systems. Patient-initiated appointment systems may have little or no effect on adverse events such as relapse or patient satisfaction compared to consultant-led appointment systems.

\section{PLAIN LANGUAGE SUMMARY}

\section{Patient-initiated appointments for people with chronic conditions managed in hospital outpatient settings}

\section{What is the aim of this review?}

We aimed to establish if patient-initiated appointments (appointments requested by the patient) for people with chronic and recurrent conditions is a better way of managing care in hospital outpatient settings than standard appointments scheduled by the consultant. Researchers found 17 studies to analyse.

\section{Key messages}

Overall, this review provides mainly low-quality evidence that patient-initiated appointment systems may have little or no impact on patient anxiety, depression, quality of life, adverse events and satisfaction. This system may also have little or no impact on the contact that patients have with services but impact on the costs of the service are unclear. There is some variability in the way patients experience care.

\section{What is studied in the review?}

Follow-up appointments scheduled by a hospital consultant is currently used for people with chronic conditions such as (but not limited to) rheumatoid arthritis, inflammatory bowel disease and cancer. This system often results in missed appointments, patients unable to access care when they need it, and a backlog of patients waiting to be diagnosed or treated for the first time. Allowing patients to access healthcare advice and appointments when they need it (patient-initiated appointments) could help alleviate these problems and free-up appointments. The patient-initiated system of care may also lead to greater satisfaction for patients with a more convenient service, and may reduce costs for patients and service providers. This review compares patient-initiated appointment systems that allow the patient to telephone a specialist nurse on a helpline, where they can discuss their query first, and have an appointment with the consultant booked as necessary, to consultant-led appointment systems. We want to know if these systems are safe for patients to use, if patients and clinicians find them appropriate and satisfactory to use, how they may impact patients physical and mental health, and how they may impact on health service resources and costs.

\section{What are the main results of the review?}


The review identified 17 studies. The studies covered six health conditions cancer (seven studies), rheumatoid arthritis (four), digestive conditions (three), asthma (one), psoriasis (one) and coronary obstructive pulmonary disease (one). Most studies were based in the UK (nine) but Sweden (three), Denmark (three), Finland (one) and the Netherlands (one) were also represented. The mean age of the 3854 patients ranged from 41 to 76 years and most were female. The results suggest patient-initiated appointment systems may make little or no difference to patient anxiety, depression and quality of life compared to the consultant-led appointment system (low-quality evidence due to high risk of bias and variation in results). Other aspects of disease status and experience also appear to show little or no difference between patient-initiated and consultant-led appointment systems. Results for service utilisation (contact with health services and staff) suggest there may be little or no difference in service contacts between the patient-initiated and consultant-led services (low-quality evidence due to different levels of contact reported across studies making it difficult to assess). We do not know if service utilisation (costs of services or staff) are reduced in the patient-initiated compared to the consultant-led appointment groups as the quality of this evidence is very low (due to the risk of bias and the variability of currencies and levels of costs reported across studies). The results suggest that there may be little or no impact on adverse events such as relapses in some conditions (cancer or inflammatory bowel disease) in the patientinitiated appointment group in comparison with the consultant-led appointment group (low-quality evidence due to the inconsistency and precision across studies in reporting and measuring relapse). The results suggest there may be little or no impact on patient satisfaction (low-quality evidence as each study used different questions to collect their data at different time points and across different illnesses). Not all studies reported their funding sources, but of those that were reported, most were funded by not-for-profit organisations. One study (on asthma) was funded by a pharmaceutical company.

\section{How up-to-date is this review?}

The review authors searched for studies that had been published up to March 2019. 


\section{SUMMARY OF FINDINGS}

\section{Summary of findings for the main comparison. Patient-initiated appointment systems compared with consultant-} led appointment systems for people with chronic conditions

\section{Patient-initiated appointment systems compared with consultant-led appointment systems for people with chronic condi- tions}

Patient or population: adults with a chronic or recurrent condition

Settings: secondary care

Intervention: patient-initiated appointment systems

Comparison: consultant-led appointment systems

\begin{tabular}{|c|c|c|c|c|}
\hline Outcomes & $\begin{array}{l}\text { Relative ef- } \\
\text { fect } \\
(95 \% \mathrm{CI})\end{array}$ & $\begin{array}{l}\text { No of par- } \\
\text { ticipants } \\
\text { (studies) }\end{array}$ & $\begin{array}{l}\text { Certainty } \\
\text { of the ev- } \\
\text { idence } \\
\text { (GRADE) }\end{array}$ & Comments \\
\hline $\begin{array}{l}\text { Patient out- } \\
\text { comes: anxiety } \\
\text { (HADS) } \\
\text { 12-24 months }\end{array}$ & $\begin{array}{l}\text { OR } 0.87 \\
(0.68 \text { to } 1.12)\end{array}$ & $\begin{array}{l}1019 \\
\text { (5) }\end{array}$ & $\begin{array}{l}\oplus \oplus \ominus \ominus \\
\text { Lowb }\end{array}$ & $\begin{array}{l}7 \text { studies reported anxiety, } 2 \text { could not be included in the analysis } \\
\text { due to data available, but findings appeared consistent. Heterogene- } \\
\text { ity in health condition (cancer, psoriasis and RA), participants and } \\
\text { follow-up. }\end{array}$ \\
\hline $\begin{array}{l}\text { Patient out- } \\
\text { comes: de- } \\
\text { pression } \\
\text { (HADS) }\end{array}$ & $\begin{array}{l}\text { OR } 0.79 \\
(0.51 \text { to } 1.23)\end{array}$ & $\begin{array}{l}1835 \\
(6)\end{array}$ & $\begin{array}{l}\oplus \oplus \ominus \ominus \\
\text { Lowb }\end{array}$ & $\begin{array}{l}7 \text { studies reported depression, } 1 \text { could not be included in the analysis } \\
\text { due to data available, but findings appeared consistent. Heterogene- } \\
\text { ity in health condition (cancer, RA, psoriasis and IBD), participants } \\
\text { and follow-up. }\end{array}$ \\
\hline $\begin{array}{l}\text { Patient out- } \\
\text { comes: quality } \\
\text { of life } \\
\text { (different scales } \\
\text { used across } \\
\text { studies) } \\
12-18 \text { months }\end{array}$ & $\begin{array}{l}\text { SMD } 0.12 \\
(0.00 \text { to } 0.25)\end{array}$ & $\begin{array}{l}1486 \\
(7)\end{array}$ & $\begin{array}{l}\oplus \oplus \odot \odot \\
\text { Lowb }\end{array}$ & $\begin{array}{l}12 \text { studies reported quality of life, } 5 \text { could not be included due to da- } \\
\text { ta available, but where some data were available findings appeared } \\
\text { consistent. Heterogeneity in health condition (asthma, IBD, psoria- } \\
\text { sis, RA and cancer) and tools used to measure quality of life. }\end{array}$ \\
\hline $\begin{array}{l}\text { Service utilisa- } \\
\text { tion (contacts) } \\
12 \text { months }\end{array}$ & $\begin{array}{l}\text { Contact rate } \\
\text { ratio ranged } \\
\text { from } 0.68 \text { to } \\
3.83 \text { (medi- } \\
\text { an rate ratio } \\
1.11, \text { IQR } 0.93 \\
\text { to } 1.37 \text { ) }\end{array}$ & $\begin{array}{l}3348 \\
(15)\end{array}$ & $\begin{array}{l}\oplus \oplus \ominus \ominus \\
\text { Lowc }^{c}\end{array}$ & $\begin{array}{l}\text { Studies included different elements of service contact in their data, } \\
\text { and may expect contact to vary across health condition. }\end{array}$ \\
\hline $\begin{array}{l}\text { Service utilisa- } \\
\text { tion (costs) } \\
\text { per patient per } \\
\text { year }\end{array}$ & $\begin{array}{l}\text { Studies re- } \\
\text { ported the } \\
\text { intervention } \\
\text { group may } \\
\text { have had } \\
\text { higher or low- } \\
\text { er costs than }\end{array}$ & 2235 & $\begin{array}{l}\oplus \odot \odot \odot \\
\text { Very } \\
\text { lowd }\end{array}$ & $\begin{array}{l}\text { Studies included different elements of service costs in their data, da- } \\
\text { ta were presented in different currencies and it may be expected that } \\
\text { service costs vary across health condition. }\end{array}$ \\
\hline
\end{tabular}




\begin{tabular}{|c|c|c|c|c|}
\hline & $\begin{array}{l}\text { the control } \\
\text { group. }\end{array}$ & & & \\
\hline $\begin{array}{l}\text { Adverse } \\
\text { events - re- } \\
\text { lapse }\end{array}$ & $\begin{array}{l}\text { MD }-\mathbf{0 . 2 0} \\
(-0.54 \text { to } 0.14)\end{array}$ & $\begin{array}{l}888 \\
(3)\end{array}$ & $\begin{array}{l}\oplus \oplus \Theta \ominus \\
\text { Low }^{\mathrm{e}}\end{array}$ & $\begin{array}{l}5 \text { studies reported adverse events as relapse or recurrence, } 2 \text { could } \\
\text { not be included in the analysis due to data available but findings ap- } \\
\text { peared consistent. Each study used different questions/definitions } \\
\text { to collect their data at difference time points and across different } \\
\text { health conditions (inflammatory bowel disease and cancer). }\end{array}$ \\
\hline $\begin{array}{l}\text { Patient satis- } \\
\text { faction } \\
6-72 \text { months }\end{array}$ & $\begin{array}{l}\text { SMD } 0.05 \\
(-0.41 \text { to } 0.52)\end{array}$ & $\begin{array}{l}375 \\
(2)\end{array}$ & $\begin{array}{l}\oplus \oplus \Theta \ominus \\
\text { Low }^{f}\end{array}$ & $\begin{array}{l}12 \text { studies reported patient satisfaction, } 10 \text { could not be included in } \\
\text { the analysis due to data available but findings appeared broadly con- } \\
\text { sistent. Each study used different questions to collect their data at } \\
\text { different time points and across different health conditions. No stud- } \\
\text { ies reported on clinician satisfaction. }\end{array}$ \\
\hline
\end{tabular}

CI: confidence interval; HADS: Hospital Anxiety and Depression Scale; IBD: inflammatory bowel disease; IQR: interquartile range; MD: mean difference; OR: odds ratio; RA: rheumatoid arthritis; SMD: standardised mean difference.

GRADE Working Group grades of evidence

High-certainty: further research is very unlikely to change our confidence in the estimate of effect.

Moderate-certainty: further research is likely to have an important impact on our confidence in the estimate of effect and may change the estimate.

Low-certainty: further research is very likely to have an important impact on our confidence in the estimate of effect and is likely to change the estimate.

Very low-certainty: we are very uncertain about the estimate.

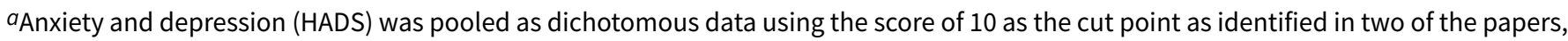
continuous data were converted to dichotomous data as no other data could be retrieved from the papers presenting dichotomous data for these outcomes.

bDowngraded two levels due serious risk of bias (lack of blinding, incomplete and selective reporting) and serious imprecision (wide confidence intervals).

cDowngraded two levels due to serious risk of bias (lack of blinding) and serious indirectness (different levels of contact reported across studies); consistency and precision difficult to assess.

dDowngraded three levels due to serious risk of bias (due to incomplete data), serious indirectness (as different currencies and levels of costs reported across studies) and serious imprecision.

eDowngraded two levels due to serious risk of bias (lack of blinding, selective reporting) and serious imprecision (wide confidence intervals).

fDowngraded two levels due to serious risk of bias (lack of blinding) and serious indirectness as satisfaction was measured and reported differently across studies; consistency and precision difficult to assess. 


\section{B A C K G R O U N D}

Chronic disease has a wide impact worldwide. The World Health Organization (WHO) reported that $63 \%$ of all deaths are from chronic disease (WHO 2011).

Missed hospital appointments are commonly reported in healthcare services around the world; for example, they cost the National Health Service (NHS) in the UK millions of pounds every year (HES 2010) (estimated GBP 225 million in 2012/2013; National Audit Office 2014). This unnecessary cost and a change in public expectations has brought into question the efficiencies of outpatient appointment scheduling systems, particularly in chronic conditions. Alternative appointment systems have been explored, for example, the Expert Patient Programme (in the UK) was specifically aimed at people with long-term conditions (DoH 2001), early discharge with rapid access to care for patients with chronic obstructive pulmonary disease (COPD) in Ireland (Lawlor 2009), self-management training for people with COPD in Canada (Bourbeau 2003), specialist nurse provision for people with inflammatory bowel disease (IBD) in Belgium (Coenen 2017). Alternative forms of appointment scheduling may not be appropriate for all healthcare areas, but those managing people who have long-term or chronic conditions may see some benefits.

In 2002, the WHO published a report highlighting the need for a model of care that more readily meets the needs of people with chronic conditions (WHO 2002). The authors suggested that innovations that build on evidence-based decision-making, have a population and quality focus, and are flexible to the needs and demands of the patient population should do well in improving the management of chronic conditions.

More recently, both the NHS Long Term Plan (NHS 2019) and a report on outpatient care by the Royal College of Physicians (RCP 2018) have concluded that current, more traditional models of outpatient care are unstainable as outpatient appointments have doubled in the last 10 years. The reports highlight how outpatient care needs to be updated to be more flexible and cost effective to meet the needs of both patients and the NHS.

\section{Description of the condition}

Chronic conditions, defined as "diseases of long duration and generally slow progression" (WHO 2013), include rheumatoid arthritis, asthma, cancer and diabetes. People are faced with an opportunity to manage their condition but not cure it. Traditionally, people with these conditions are managed by the clinician through regularly scheduled appointments (e.g. one to four times per year) at outpatient clinics (Kirwan 1991; Probert 1993). These appointments often occur at a time when a person is feeling relatively well, with little action taken as a result. Conversely, when symptoms recur or suddenly worsen, it may be difficult to obtain immediate urgent appointments. Subsequently, people are often unable to get help during periods of exacerbated disease due to the number of regular follow-up appointments also scheduled in the system. In some cases, conditions are managed in primary care and several studies reported the success of similar systems in this setting (Liu 2010; Robinson 2010; Rose 2011).

\section{Description of the intervention}

A patient-initiated appointment system (PIAS) enables patients to make appointments at times when they feel they cannot manage their condition or where something has unexpectedly changed. The system does not completely replace the need for a scheduled follow-up appointment, but the new system could reduce the number of follow-up appointments, for example, to every one to two years.

\section{How the intervention might work}

The PIAS could free up clinician time, therefore making the service more flexible for urgent appointments, while still being able to deliver an acceptable standard of care. Using this type of service may also mean that the numbers of missed appointments are reduced (and therefore financial and resource costs are reduced too) as most patients will be attending because they need or choose to, and not just because the appointment is thought to be a requirement. There is a potential risk in situations where the patient fails to request an appointment at the time of relapse or escalation of their condition, and symptoms become worse, possibly critically. This risk is more likely when the appointment systems do not include a 'safety net' appointment system (an appointment which is scheduled by the clinician/researcher for a certain time to ensure the patient is using the system correctly) or when clinicians are unable to select appropriate patients for the PIAS pathway. In addition, there are elements of preventive health care or patient education that occur during a routine appointment that are not addressed during a patient-initiated appointment. This risk can be minimised by incorporating an appropriate checklist into a 'safety net' appointment. Several studies have explored the effectiveness of PIAS in primary care (Liu 2010; Robinson 2010; Rose 2011). The results of some of these studies suggest that patient initiation of care results in improvements in satisfaction with a reduced cost for care delivery (Berkhof 2014; Robinson 2001).

\section{Why it is important to do this review}

There are several Cochrane Reviews that have considered alternative methods to improve attendance to appointments (Car 2012; Reda 2012); however, none of these reviews has looked at the impact of PIAS in secondary care. With the increasing focus on healthcare efficiencies and the increasing emphasis on enabling people to manage their own conditions (NHS 2019; Nuffield 2011; WHO 2002), determining the benefits and harms of PIAS in secondary care is crucial to understanding their worth for both healthcare systems and patients.

\section{O B JECT IVES}

To assess the effects of patient-initiated appointment systems compared with consultant-led appointment systems in people with chronic or recurrent conditions managed in secondary care.

\section{METHODS}

\section{Criteria for considering studies for this review}

\section{Types of studies}

This review included randomised trials, including clusterrandomised trials (published and unpublished and in any language) that compared PIAS with consultant-led appointment systems. We did not include a broader range of study designs, as randomised trial designs are able to inform on causal relationships more reliably than non-randomised designs; this may be particularly important with this topic with the progressive and 
fluctuating nature of long-term conditions. Furthermore, we were confident there was sufficient randomised trial evidence on this topic to make evidence-based recommendations.

\section{Types of participants}

We included adults (18 years of age or older) diagnosed with any chronic or recurrent condition, which was managed in secondary care (we did not search for named conditions, the conditions included in this review are those we found evidence for).

\section{Types of interventions}

A PIAS, established in the secondary care system, where appointments can be initiated by the patient whenever they require support from a relevant health professional to manage their ongoing condition. The appointments must not have been used for the purposes of diagnosis.

The comparator was a consultant-led appointment system where patients were given a scheduled appointment to see the relevant health professional (usually a consultant) in secondary care, whether or not they required support. Other appointments were only made in case of an emergency or crisis.

The intervention described here correlates with the Effective Practice and Organisation of Care (EPOC) taxonomy of intervention co-ordination of care and management of care processes subcategories: care pathways; disease management and PIAS (EPOC 2015).

Note: PIAS within a research trial may include a 'safety net' appointment where patients do receive a scheduled appointment with a consultant as part of the research project to make sure participation is safe.

\section{Types of outcome measures}

We included studies that reported one or more of the following outcomes. Studies were not excluded based on outcome.

\section{Primary outcomes}

- Patient outcomes, such as anxiety, depression, quality of life and other health/disease status measurements (such as disease activity, disability, self-efficacy, pain and other disease specific outcomes).

- Service utilisation (contacts) - contact rates with the healthcare system including missed appointments measured through health records.

- Service utilisation (costs).

- Adverse events.

\section{Secondary outcomes}

- Other service utilisation (other involved health service professionals including those outside of secondary care).

- Patient satisfaction.

- Clinician (consultant or specialist nurse) satisfaction.

- Failures of the 'system' (e.g. how long people were on the PIAS pathway but not using it correctly before the clinical team needed to reinstigate regular follow-up clinics).

\section{Search methods for identification of studies}

\section{Electronic searches}

We searched the Cochrane Database of Systematic Reviews (CDSR) and the Database of Abstracts of Reviews of Effects (DARE) for primary studies included in related systematic reviews. We searched the following databases on 13 March 2019:

- Cochrane Central Register of Controlled Trials (CENTRAL) via Cochrane Library (2019, Issue 3);

- MEDLINE via OvidSP (1946 to 12 March 2019);

- Embase via OvidSP (1974 to 12 March 2019);

- PsycINFO via OvidSP (1806 to 12 March 2019);

- Health Technology Assessment (HTA) via CRD database (13 March 2019);

- NHS Economic Evaluation Database (NHS EED) via CRD database (13 March 2019);

- CINAHL via EBSCOhost (1937 to 13 March 2019);

- Health Management Information Consortium (HMIC) via OvidSP (1979 to 13 March 2019);

- ProQuest Dissertations \& Theses Global via ProQuest (2015 to 13 March 2019).

Search strategies were comprised of keywords and controlled vocabulary terms. We applied no language or time limits. Search strategies for all databases can be found in Appendix 1 .

\section{Searching other resources}

We searched for current/ongoing research on the following trial registries:

- WHO International Clinical Trials Registry Platform (ICTRP www.who.int/ictrp/en/; searched 15 March 2019);

- ClinicalTrials.gov, US National Institutes of Health $(\mathrm{NIH}$; clinicaltrials.gov/; searched 15 March 2019).

We also:

- searched PROSPERO for registered systematic reviews (www.crd.york.ac.uk/prospero/; searched 15 March 2019);

- reviewed reference lists of all included studies, relevant systematic reviews/primary studies;

- contacted authors of relevant studies/reviews to clarify reported published information and to seek unpublished results/data;

- contacted researchers with expertise relevant to the review topic/ EPOC interventions;

- conducted a cited reference search for all included studies in Scopus (4 April 2019).

\section{Data collection and analysis}

\section{Selection of studies}

Two review authors (pairs of RW, JT-C, RA, MR, VG, LA, SB) independently screened all references at the title and abstract stage using prespecified inclusion criteria. We resolved disagreements though discussion. At the full-text stage, two review authors (pairs of RW, MR, VG, LA, SB) independently screened all references; we discussed disagreements and resolved them with a 
third review author (JT-C, RA, MP, or KS). We recorded reasons for exclusion at the full-text stage and recorded the selection process in sufficient detail to complete a PRISMA flow diagram (Liberati 2009).

\section{Data extraction and management}

Two review authors (pairs of RW, RA, MR, VG, LA, SB) independently completed data extraction for all included studies. The data extraction covered details, such as information on the participants, setting, interventions and comparisons, outcomes and study design, and we piloted this before use (Appendix 2; EPOC 2017a). We discussed and resolved discrepancies with a third review author (JTC, MP, or KS) where necessary. We contacted authors of included papers to request clarifications and provide additional data, and where possible, entered the data into Review Manager 5 (Review Manager 2014).

\section{Assessment of risk of bias in included studies}

Two review authors (pairs of RW, RA, MR, VG, LA, SB) independently assessed the risk of bias using the Cochrane 'Risk of bias' tool (Higgins 2011). Items in this tool include sequence generation, allocation concealment, blinding of participants and personnel, blinding of outcome assessment, incomplete outcome data, selective outcome reporting and other bias (such as bias in study samples prerandomisation that are unaccounted for in analysis or inappropriate administration of the intervention itself). We assessed studies on the basis of having low, unclear or high risk of bias. We discussed and resolved discrepancies with a third review author (JTC, MP or KS) where necessary. We used the 'Risk of bias' tool to inform the analysis and interpretation of the results, but not as criteria for excluding studies from the review.

\section{Measures of treatment effect}

We expected a wide range of data (measures of treatment effect). We used mean difference (MD) when studies used the same scales or standardised mean difference (SMD) when studies used different scale with $95 \%$ confidence intervals (Cls) to quantify the difference between trial arms for continuous outcomes. We reported odds ratios (OR) with $95 \% \mathrm{Cls}$ on two analyses where we combined continuous and dichotomous data (anxiety and depression) by calculating the ORs and inputting them into Review Manager 5 to pool the data (Review Manager 2014). Anxiety and depression (using the Hospital Anxiety and Depression Scale (HADS)) were pooled as dichotomous data using the score of 10 as the cut point as identified in two of the papers, continuous data were converted to dichotomous data as no other data could be retrieved from the papers presenting dichotomous data for these outcomes. There were three analyses (rheumatoid arthritis: disability, self-efficacy and pain) where we used a fixed-effect model, as the population and measures for those outcomes were comparable. We also used Review Manager 5 to calculate the median effect, interquartile range (IQR) and SMD for continuous data. We had planned to present the risk ratios (RR) of any dichotomous data, but were unable to do so due to the data available being mixed dichotomous and continuous data in any one analysis.

\section{Unit of analysis issues}

Where studies had several points of follow-up, we selected the most common point of follow-up across studies (or the point of followup closest to the common point of follow-up) for each outcome reported in a meta-analysis, otherwise we reported the longest point of follow-up. Where studies used a cluster-randomised trial design, but did not allow for clustering in the analysis, we adjusted the standard error (SE) of estimate appropriately based on the mean cluster size (i.e. number of participants per cluster) and assumed plausible value of the intracluster correlation coefficient (ICC) (e.g. if the cluster was the hospital, then we assumed values for the ICC between 0 and 0.3 for patient outcomes).

\section{Dealing with missing data}

We contacted authors for clarification and to retrieve more information and data that we could more readily combine.

\section{Assessment of heterogeneity}

We quantified heterogeneity across estimates using the $1^{2}$ statistic. We expected that the type of condition would add to the heterogeneity of the results as well as the content/structure of the PIAS.

\section{Assessment of reporting biases}

We did not examine the likelihood of publication bias due to the low number of studies included in the meta-analyses. Had it been appropriate, we would have used Egger's regression test for asymmetry (metabias command in Stata) and funnel plots.

\section{Data synthesis}

Our analyses combined estimates of the effect of PIAS on the outcomes across studies. We used random-effects meta-analyses to pool the estimates using the DerSimonian-Laird method (DerSimonian 1986). We performed the meta-analysis using Review Manager 5 (Review Manager 2014). Where studies used different continuous measures to quantify a given outcome (e.g. quality of life - 36-item Short Form (SF-36), 12-item Short Form (SF-12), Inflammatory Bowel Disease Questionnaire (IBDQ), St George's Respiratory Questionnaire (SGRQ), etc.), we pooled the SMD. Where meta-analysis was not possible, we presented the data in tables to best describe and summarise them. In particular, we could not pool the data on service utilisation due to the varying descriptions of the services used and variation in currency. Instead, the service utilisation tables aim to provide a summary of the results while taking a detailed account of the limitations and descriptions of the data. We calculated the person-years by multiplying the number of people in the control/intervention arm by the number of years at follow-up. We calculated the rate ratio (as in Analysis 1.9) by dividing the sum of the (intervention person-years divided by the intervention total contacts) by the sum of the (control person-years divided by the control total contacts) $=$ rate ratio (e.g. Brown 2002; $(28 / 6=4.67) /(26 / 4=6.5)=0.72)$. We also calculated the median of the contact rate ratio to summarise the intervention effects on service utilisation in terms of contact with professionals, but this was not appropriate for the analysis of costs, due to the varying currencies used.

\section{Summary of findings}

We created a 'Summary of findings' table for the comparison, PIAS versus consultant-led appointments, and included the most important outcomes in order to draw conclusions about the certainty of the evidence within the text of the review. We included the primary outcomes of anxiety, depression, quality of life, service utilisation (contacts and costs), and adverse events (relapse) and the secondary outcome of patient satisfaction, as these are all 
important for decision-making (clinician satisfaction is reported as a comment).

Two review authors (RW, RA) independently assessed the certainty of the evidence (high, moderate, low, and very low) using the five GRADE considerations (risk of bias, consistency of effect, imprecision, indirectness and publication bias) (Guyatt 2008). We used GRADEpro to develop the GRADE table (GRADEpro GDT), and resolved disagreements on certainty ratings by discussion and provided justification for decisions to downgrade or upgrade the ratings using footnotes in the table to aid readers' understanding of the review. We used plain language statements to report these findings in the review (EPOC 2017b).

Where it was not possible to meta-analyse the data, we summarised the results in the text.

\section{Subgroup analysis and investigation of heterogeneity}

We conducted analyses to investigate whether pooled estimates differed across subgroups such as health condition. We conducted a subgroup analysis by health condition for the outcomes that had three or more studies with useable data (anxiety, depression and quality of life). No other outcomes were eligible for subgroup analysis. We were unable to conduct a subgroup analysis based on age.

\section{Sensitivity analysis}

Sensitivity analysis would have been conducted in the case of missing data particularly in regards to where length of followup, attrition rates and units of analysis were missing or unclear. Sensitivity analyses were conducted to check the robustness of the results to potential risk of bias. Studies judged to be of high risk of bias for sequence generation or allocation concealment (or both) were excluded in secondary analyses.

\section{RES U L T S}

\section{Description of studies}

For a full description of included studies, see Characteristics of included studies table, and for excluded studies, see Characteristics of excluded studies table.

\section{Results of the search}

Figure 1 presents the search of included studies from the literature searches. We screened 18,917 titles and abstracts for inclusion, of these, we retrieved 50 full-text articles and finally included 26 references in the review (Figure 1). The 26 references referred to 17 studies with multiple references to four studies, reflecting differing periods of follow-up and cost-effectiveness analyses. 
Figure 1. Study flow diagram.

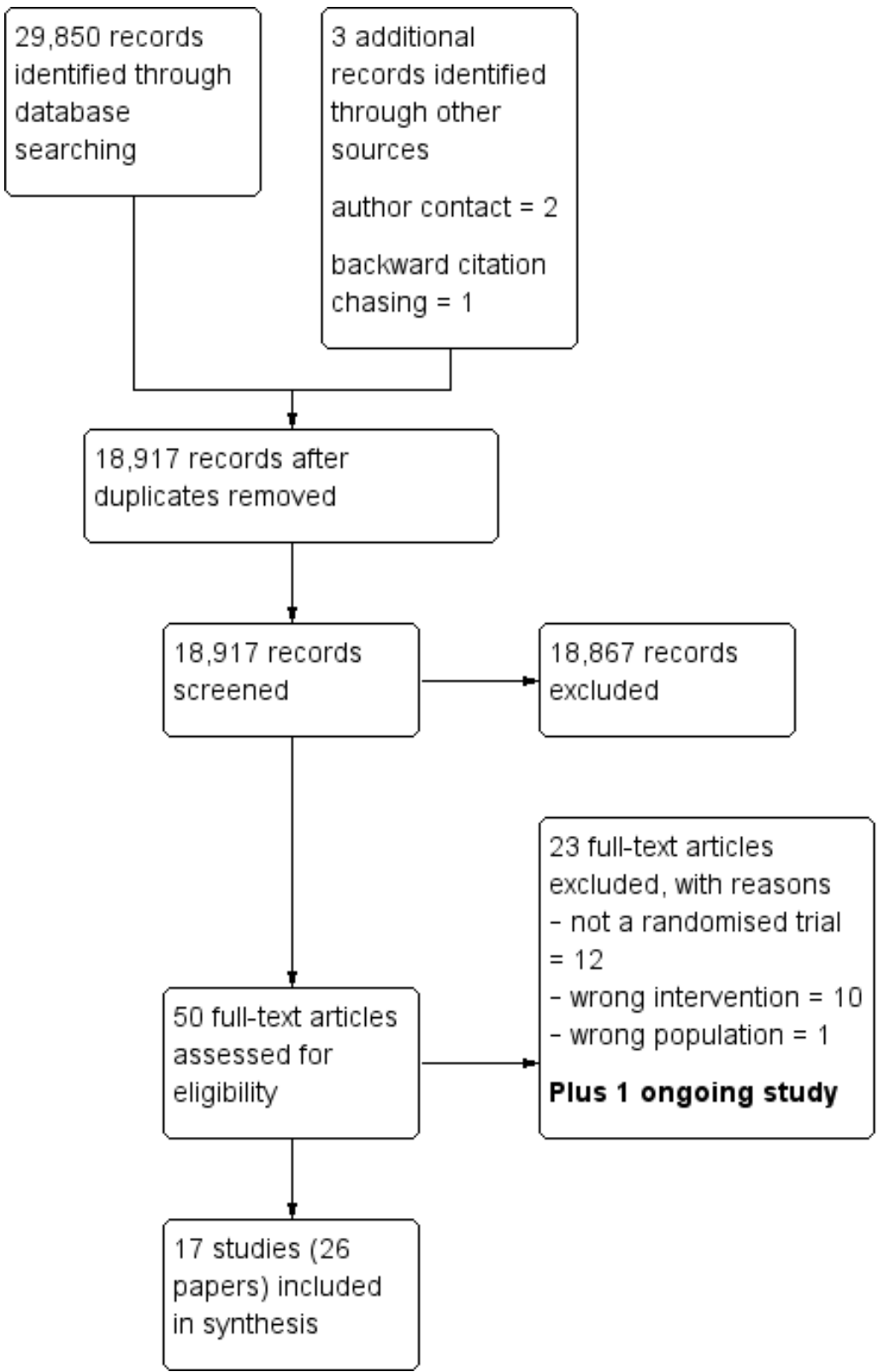

\section{Included studies}

\section{Study characteristics}

We included 17 randomised trials (seven single site and 10 multisite including one cluster randomised) in the review. Nine studies were set in the UK, three in Sweden, three in Denmark, one in Finland and one in the Netherlands.

\section{Population}

The populations represented in these studies had a mean age ranging from 41 to 76 years. The studies covered six broad health conditions: cancer (breast: Brown 2002; Gulliford 1997; Kirshbaum 2017; Koinberg 2004; Sheppard 2009; prostate: Helgesen 2000; endometrial: Jeppesen 2018); rheumatoid arthritis (Fredriksson 2016; Goodwin 2016; Hewlett 2000; Primdahl 2012); digestive conditions (IBD: Kennedy 2003; Williams 2000; ulcerative colitis:
Robinson 2001); asthma (Lahdensuo 1996); psoriasis (Khoury 2018); and coronary obstructive pulmonary disease (Berkhof 2014). The cancer studies had either men or women in their populations but the other health conditions used mixed populations, although women dominated in almost every mixed study (nine reported 52\% to $77 \%$ with one study at $26 \%$ and one at $36 \%$ ), which may reflect an increased incidence of these conditions within women. The sample sizes ranged from 61 to 635 participants (total 3854), and length of follow-up ranged from 10 to 72 months.

\section{Interventions}

The interventions all involved patients (or the patients' GP) being able to access disease-specific advice and care by telephoning their hospital. In most interventions, the patient contacted a specialist nurse who was able to give immediate advice, ask a doctor for further advice to give to the patient and arrange an 
outpatient appointment if necessary. When enrolling into the intervention, some patients were given personal education by trained nurses (Kirshbaum 2017; Lahdensuo 1996), or doctors (Jeppesen 2018); some were given general written information/ guidance (Brown 2002; Hewlett 2000; Kirshbaum 2017); and some received a personalised guided self-management plan (Kennedy 2003; Robinson 2001). The remaining studies did not report this level of detail, though some written materials may be assumed in the process of enrolling within the healthcare context. Most studies ran a safety net procedure for the duration of the study in the form of an annual hospital review (Berkhof 2014; Goodwin 2016; Khoury 2018; Primdahl 2012); an annual mammogram (Brown 2002; Gulliford 1997; Koinberg 2004; Sheppard 2009); or another review or contact at three months (Hewlett 2000; Fredriksson 2016), four months (Lahdensuo 1996), six months (Helgesen 2000), or 24 months (Williams 2000). Only four studies reported no safety net procedures (Jeppesen 2018; Kennedy 2003; Kirshbaum 2017; Robinson 2001).

\section{Comparisons}

The comparator for each study was a consultant-led clinic appointment with varying appointment schedules across the studies. Some studies reported that those in the comparator condition could receive an emergency appointment if necessary (Fredriksson 2016; Gulliford 1997; Helgesen 2000; Hewlett 2000; Khoury 2018; Primdahl 2012; Williams 2000), but for the remainder the availability of this service was unclear. For full details, see the Characteristics of included studies tables.

\section{Outcomes}

The review included the following outcomes (studies were not excluded based on outcome).

\section{Primary outcomes}

Sixteen studies reported on patient outcomes, such as anxiety (Brown 2002; Helgesen 2000; Hewlett 2000; Kennedy 2003; Khoury 2018; Kirshbaum 2017; Koinberg 2004); depression (Brown 2002; Helgesen 2000; Hewlett 2000; Kennedy 2003; Khoury 2018; Kirshbaum 2017; Koinberg 2004); quality of life (Berkhof 2014; Brown 2002; Gulliford 1997; Hewlett 2000; Kennedy 2003; Khoury 2018; Kirshbaum 2017; Lahdensuo 1996; Primdahl 2012; Robinson 2001; Sheppard 2009; Williams 2000); and other health/disease status measurements such as disease activity (Hewlett 2000; Primdahl 2012), disability (Hewlett 2000; Primdahl 2012), selfefficacy (Hewlett 2000; Primdahl 2012), pain (Hewlett 2000; Primdahl 2012), and other disease-specific outcomes (Berkhof 2014; Brown 2002; Fredriksson 2016; Gulliford 1997; Helgesen 2000; Hewlett 2000; Jeppesen 2018; Kennedy 2003; Khoury 2018; Koinberg 2004; Lahdensuo 1996; Primdahl 2012; Robinson 2001; Sheppard 2009; Williams 2000).
Fifteen studies reported on service utilisation, such as contact rates with the healthcare system (Brown 2002; Fredriksson 2016; Goodwin 2016; Gulliford 1997; Helgesen 2000; Hewlett 2000; Jeppesen 2018; Kennedy 2003; Khoury 2018; Koinberg 2004; Lahdensuo 1996; Primdahl 2012; Robinson 2001; Sheppard 2009; Williams 2000), including missed appointments measured through health records (Kennedy 2003; Khoury 2018), and costs (Berkhof 2014; Goodwin 2016; Helgesen 2000; Hewlett 2000; Kennedy 2003; Koinberg 2004; Primdahl 2012; Williams 2000).

Four studies reported on adverse events (Berkhof 2014; Kennedy 2003; Robinson 2001; Sheppard 2009).

\section{Secondary outcomes}

No studies reported on other service utilisation other than that which was captured in service utilisation contacts.

Twelve studies reported on patient satisfaction in some way (Brown 2002; Fredriksson 2016; Goodwin 2016; Gulliford 1997; Helgesen 2000; Hewlett 2000; Kennedy 2003; Khoury 2018; Koinberg 2004; Primdahl 2012; Robinson 2001; Williams 2000).

No studies reported on clinician (consultant or specialist nurse) satisfaction.

One study reported on failures of the 'system' such as 'safety net' failure (Hewlett 2000).

\section{Funding source}

Of the 17 studies, two did not report their funding source (Brown 2002; Kirshbaum 2017). Of the 15 studies that did report their funding source, 14 were funded by not-for-profit organisations such as local government or health groups or health charity organisations, one study was funded by an industry organisation.

\section{Excluded studies}

We excluded 23 studies at the full-text screening stage: 12 because they were not a randomised trial, 10 were the wrong intervention and one had the wrong population. See Characteristics of excluded studies table for full details.

\section{Ongoing studies}

We identified one ongoing study, which commenced in 2015 and the findings are yet to be reported. See Characteristics of ongoing studies table for full details.

\section{Risk of bias in included studies}

See the 'Risk of bias' tables within the Characteristics of included studies table, Figure 2 for a summary of judgements about each risk of bias item and Figure 3 for a graph of risk of bias items presented as percentages across all included studies. 
Figure 2. Risk of bias summary: review authors' judgements about each risk of bias item for each included study.

\begin{tabular}{|c|c|c|c|c|c|c|c|}
\hline & 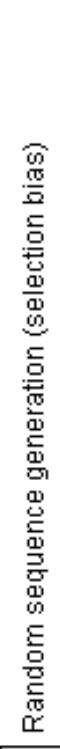 & 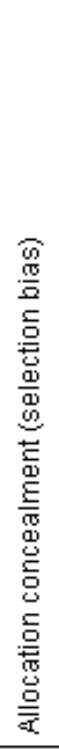 & 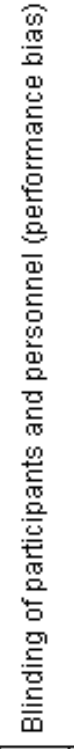 & 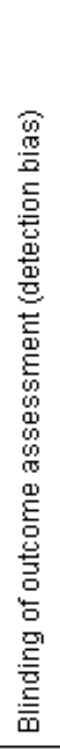 & 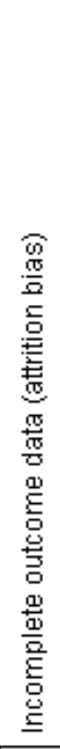 & 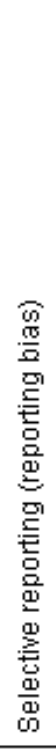 & $\begin{array}{l}\frac{0}{0} \\
\frac{.0}{5} \\
\frac{5}{2} \\
\stackrel{5}{5} \\
0\end{array}$ \\
\hline Berkhof 2014 & + & $?$ & $O$ & $\odot$ & + & + & + \\
\hline Brown 2002 & + & $?$ & - & $\odot$ & 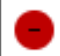 & + & $\odot$ \\
\hline Fredriksson 2016 & + & + & $\odot$ & $?$ & + & + & $\odot$ \\
\hline Goodwin 2016 & + & $?$ & 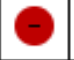 & $\odot$ & - & + & + \\
\hline Gulliford 1997 & $?$ & $?$ & $?$ & $\Theta$ & $?$ & - & + \\
\hline Helgesen 2000 & $?$ & + & 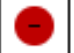 & $\odot$ & 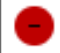 & + & $\oplus$ \\
\hline Hewlett 2000 & + & + & 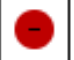 & $\odot$ & + & $\odot$ & 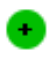 \\
\hline Jeppesen 2018 & + & + & $\theta$ & $\Theta$ & + & O & $\Theta$ \\
\hline Kennedy 2003 & + & + & 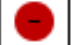 & $\Theta$ & + & + & + \\
\hline Khoury 2018 & + & $?$ & 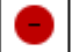 & $\odot$ & + & - & $\oplus$ \\
\hline Kirshbaum 2017 & $?$ & $?$ & $O$ & $\odot$ & $?$ & + & $?$ \\
\hline Koinberg 2004 & + & + & $\Theta$ & $\Theta$ & ? & $\Theta$ & $\partial$ \\
\hline Lahdensuo 1996 & + & + & $\theta$ & $?$ & $\theta$ & + & + \\
\hline Primdahl 2012 & + & $\odot$ & 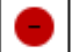 & $\odot$ & + & + & + \\
\hline Robinson 2001 & + & + & $O$ & $?$ & + & $\odot$ & $\odot$ \\
\hline Sheppard 2009 & + & + & 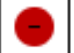 & $\odot$ & $\odot$ & + & - \\
\hline Williams 2000 & + & $\oplus$ & 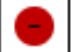 & $\odot$ & + & + & $?$ \\
\hline
\end{tabular}


Figure 3. Risk of bias graph: review authors' judgements about each risk of bias item presented as percentages across all included studies.

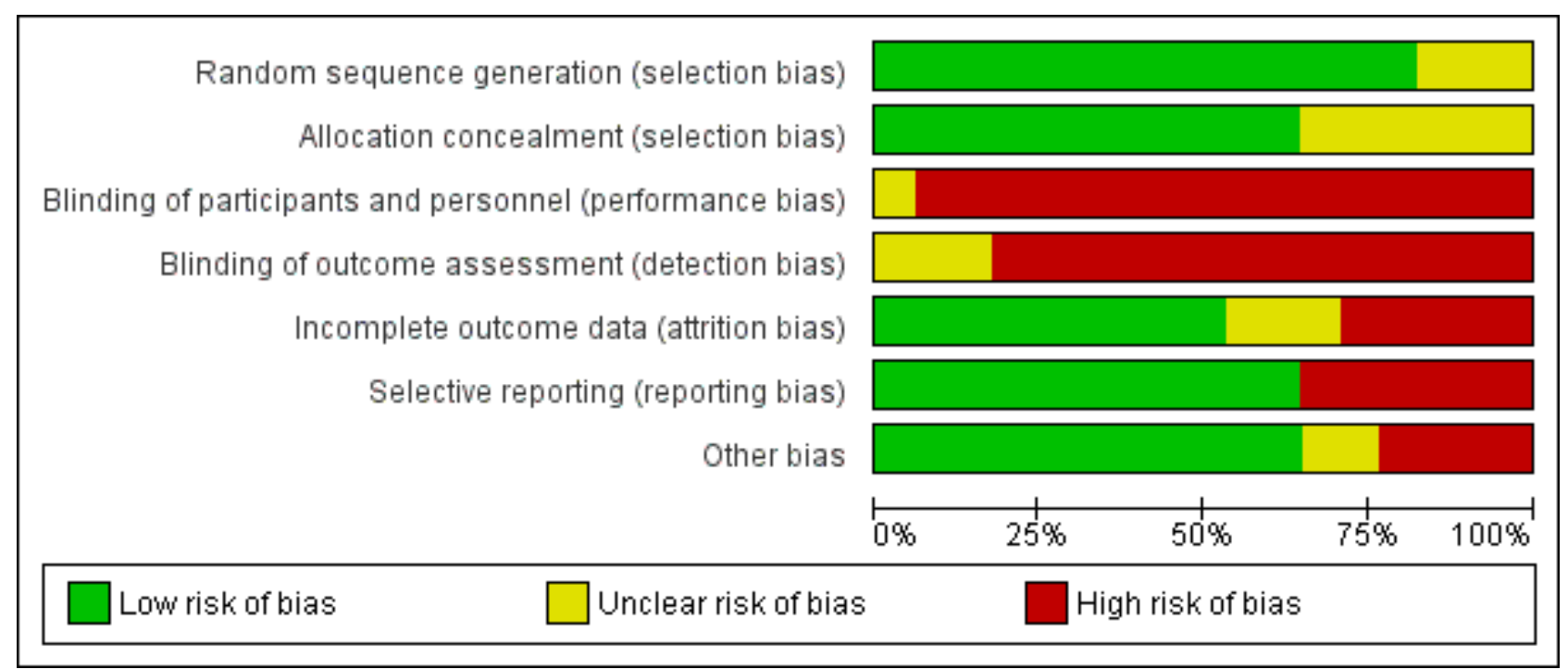

\section{Allocation}

\section{Random sequence generation}

Random sequence generation was low risk in 14 studies with methods such as computer-generated randomisation, numbers pulled randomly from a hat or random number tables (Berkhof 2014; Brown 2002; Fredriksson 2016; Goodwin 2016; Hewlett 2000; Jeppesen 2018; Kennedy 2003; Khoury 2018; Koinberg 2004; Lahdensuo 1996; Primdahl 2012; Robinson 2001; Sheppard 2009; Williams 2000). There were three studies at unclear risk due to the lack of reporting on the random sequence generation (Gulliford 1997; Helgesen 2000; Kirshbaum 2017). No studies were at high risk.

\section{Allocation concealment}

Allocation concealment was at low risk in 11 studies where allocations were concealed in sealed envelopes or dealt with by a third party not directly involved in the study, or both (Fredriksson 2016; Helgesen 2000; Hewlett 2000; Jeppesen 2018; Kennedy 2003; Koinberg 2004; Lahdensuo 1996; Primdahl 2012; Robinson 2001; Sheppard 2009; Williams 2000). There were six studies at unclear risk due to the lack of reporting on the allocation concealment (Berkhof 2014; Brown 2002; Goodwin 2016; Gulliford 1997; Khoury 2018; Kirshbaum 2017). No studies were at high risk.

\section{Blinding}

\section{Blinding of participants and personnel}

No studies were at low risk of blinding of participants and personnel as, due to the nature of the intervention, participants would know which arm of the trial they were in. There was one study at unclear risk due to the lack of reporting on the this area of blinding (Gulliford 1997). Sixteen studies were at high risk due to the obvious nature of the intervention (whether they were given allocated appointments by the consultant or were able to make their own appointments) (Berkhof 2014; Brown 2002; Fredriksson 2016; Goodwin 2016; Helgesen 2000; Hewlett 2000; Jeppesen 2018; Kennedy 2003; Khoury 2018; Kirshbaum 2017; Koinberg 2004; Lahdensuo 1996; Primdahl 2012; Robinson 2001; Sheppard 2009; Williams 2000).

\section{Blinding of outcome assessment}

No studies were at low risk of blinding of outcome assessment as many of the outcomes were self-reported and this may have influenced the interpretation of the results around these outcomes. There were three studies at unclear risk due to the lack of reporting (Fredriksson 2016; Lahdensuo 1996; Robinson 2001). Fourteen studies were at high risk due to the obvious nature of the intervention (whether they were given allocated appointments by the consultant or were able to make their own appointments); this is largely due to the self-reporting nature of the outcomes of interest by the patients or because the blinding of other outcome assessors was not reported or unclear (Berkhof 2014; Brown 2002; Goodwin 2016; Gulliford 1997; Helgesen 2000; Hewlett 2000; Jeppesen 2018; Kennedy 2003; Khoury 2018; Kirshbaum 2017; Koinberg 2004; Primdahl 2012; Sheppard 2009; Williams 2000).

\section{Incomplete outcome data}

Incomplete outcome data was at low risk for nine studies (Berkhof 2014; Fredriksson 2016; Hewlett 2000; Jeppesen 2018; Kennedy 2003; Khoury 2018; Primdahl 2012; Robinson 2001; Williams 2000). Three studies were at unclear risk due to the poor reporting of this outcome in those studies (Gulliford 1997; Kirshbaum 2017; Koinberg 2004). Five studies were at high risk of incomplete outcome data as it was sometimes unclear where the attrition lay or why data was lost or where lost data was not accounted for appropriately in the analysis (Brown 2002; Goodwin 2016; Helgesen 2000; Lahdensuo 1996; Sheppard 2009).

\section{Selective reporting}

Selective reporting was at low risk in 11 studies where all the outcomes appeared to be reported for the necessary time points (Berkhof 2014; Brown 2002; Fredriksson 2016; Goodwin 2016; Helgesen 2000; Kennedy 2003; Kirshbaum 2017; Lahdensuo 1996; Primdahl 2012; Sheppard 2009; Williams 2000). Six studies were at high risk, one as it did not report the results of all participants but only those who completed all the assessments and there are no details about those who did not complete all the assessments or why (Hewlett 2000), and five that did not fully report all the 
outcomes they specified (Gulliford 1997; Jeppesen 2018; Khoury 2018; Koinberg 2004; Robinson 2001).

\section{Other potential sources of bias}

In other potential sources of bias, we looked at anything else that could have affected the study results that could not be accounted for above such as problems with study samples prerandomisation or problems with inappropriate administration of the intervention itself. In this area, 11 studies were at low risk where there was no evidence of further bias (Berkhof 2014; Fredriksson 2016; Goodwin 2016; Gulliford 1997; Helgesen 2000; Hewlett 2000; Kennedy 2003; Khoury 2018; Lahdensuo 1996; Primdahl 2012; Robinson 2001). Two studies were at unclear risk where there was a difference in the administration of the intervention but the impact on the results was difficult to establish (Kirshbaum 2017; Williams 2000). Four studies were at high risk of other bias due to these studies having unaccounted for instances of participants declining to participate in part due to not wanting to be randomised - this could be showing some type of characteristic difference in the participants which the study was unable to explore or account for (Brown 2002; Jeppesen 2018; Koinberg 2004; Sheppard 2009). One study also reported difficulties with administering the intervention itself but this was not further described (Koinberg 2004).

\section{Effects of interventions}

See: Summary of findings for the main comparison Patientinitiated appointment systems compared with consultant-led appointment systems for people with chronic conditions

We were able to perform meta-analyses across health conditions on three outcomes (anxiety, depression and quality of life). We were also able to perform a series of small meta-analyses within the studies on rheumatoid arthritis for five outcomes (disease activity, disability, self-efficacy, pain and patient satisfaction) and within IBD for the outcome of relapses only. The remaining outcomes (primary and secondary) are presented in other data comparison tables. In general, collating of data from studies both within and across health conditions was limited and complex in nature due to the range of tools used to measure the same or similar concepts, the differing time points at which data were collected, the differing units data were presented in, and the differing analyses and data that were reported. These factors, alongside the risk of bias identified across studies, have led us to report the certainty of the evidence (using GRADE) in this review as ranging mainly from low to very low, meaning we are quite uncertain about the estimate of effect on all the outcomes reported (Guyatt 2008).

See Summary of findings for the main comparison.

\section{Patient-initiated appointment systems versus consultant-led appointment systems}

\section{Primary outcomes}

The studies for each of the meta-analyses were selected based on the outcome reported, the closest common time point of data available (usually 12 to 24 months) and the availability of the data in the correct format.

\section{Patient outcomes}

\section{Anxiety}

Seven studies (1780 participants) reported anxiety - four were studies that recruited people with cancer, one recruited people with psoriasis, one recruited people with IBD and one recruited people with rheumatoid arthritis, all used the Hospital Anxiety and Depression Scale (HADS) as their measure. In the HADS scale, lower scores indicate fewer symptoms of anxiety or depression (range 0 to 21). The meta-analysis was conducted using five of these studies (1019 participants) (Helgesen 2000 at 12 months; Hewlett 2000 at 24 months; Khoury 2018 at 12 months; Kirshbaum 2017 at 12 months; Koinberg 2004 at 18 months). The results suggest PIAS may make little or no difference to patient anxiety, with all studies reporting considerably wide $\mathrm{Cls}$ (OR $0.87,95 \% \mathrm{Cl} 0.68$ to $1.12 ; 5$ studies, 1019 participants; $\mathrm{I}^{2}=0 \%$; low-certainty evidence; Analysis 1.1; Figure 4). The GRADE rating of the evidence for anxiety was downgraded twice to low certainty due to serious risk of bias and imprecision. Sensitivity analysis including only studies at low risk of bias for random sequence generation, allocation concealment or for length of follow-up did not change the results. 
Figure 4. Forest plot of comparison: 1 Patient-initiated appointment systems versus consultant-led appointment systems, outcome: 1.1 Patient outcomes: anxiety (HADS lower score = better 0-21) (12-24 months).

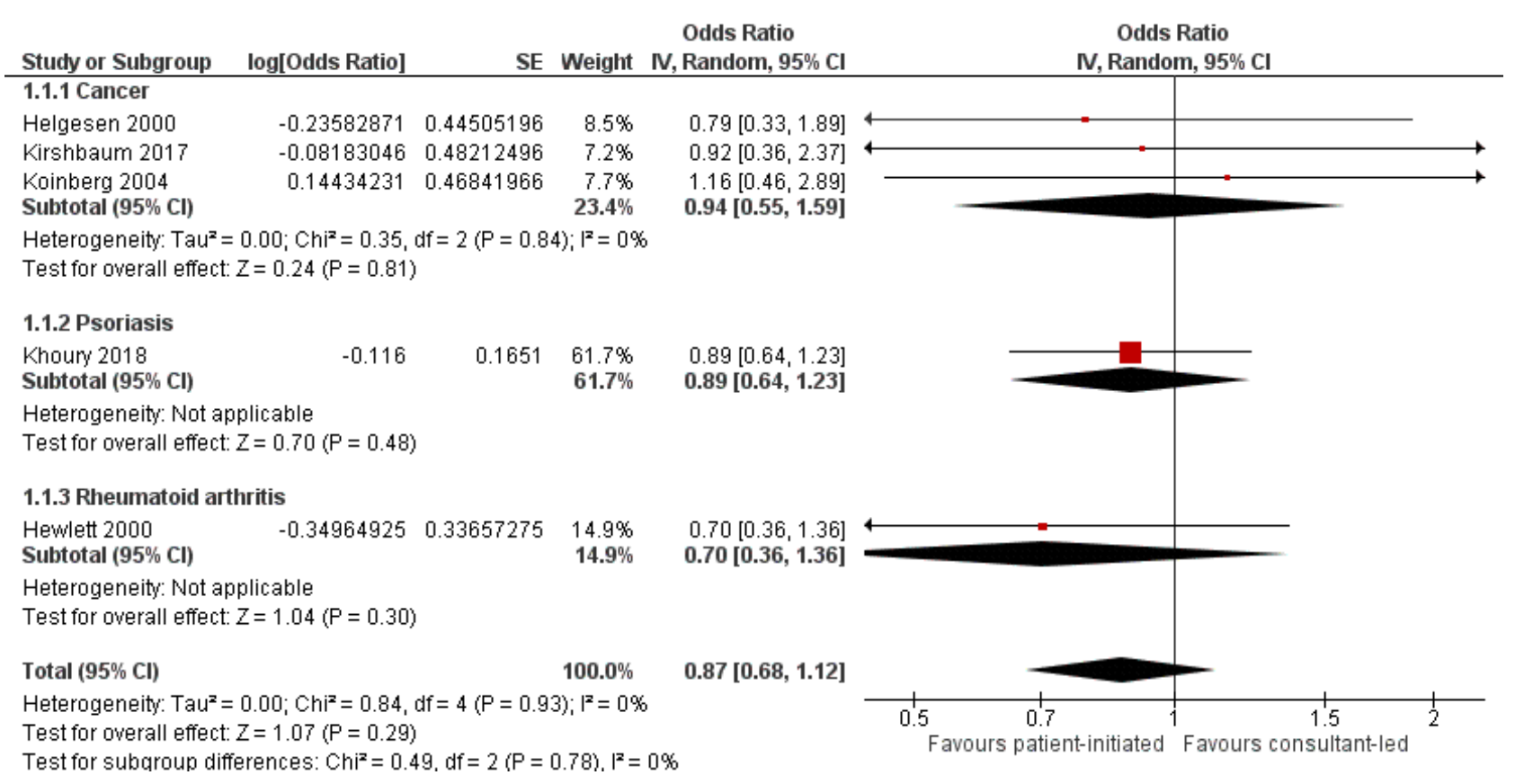

Brown 2002 and Kennedy 2003 (2 studies, 761 participants) also reported on anxiety using the same scale; however, we were unable to retrieve the necessary data to include them in the meta-analysis (Kennedy 2003 could not provide separate data for the anxiety outcome but reported no significant difference in the text - no data available). Brown 2002 also reported no significant difference in anxiety scores between the PIAS group and the consultant-led group (median score: 4 with PIAS versus 6.5 with consultant-led; P $=0.069$ at 12 months).

\section{Depression}

Seven studies (1896 participants) reported on depression - four were studies that recruited people with cancer, one recruited people with rheumatoid arthritis, one recruited people with psoriasis and one recruited people with IBD, with all using HADS as their measure (0 to 21 where lower scores indicate fewer symptoms). The meta-analysis was conducted using six of these studies (1835 participants) (Helgesen 2000 at 12 months; Hewlett 2000 at 24 months; Kennedy 2003 at nine months; Khoury 2018 at 12 months; Kirshbaum 2017 at 12 months; Koinberg 2004 at 18 months). These results suggest PIAS may make little or no difference to patient depression (OR $0.79,95 \% \mathrm{Cl} 0.51$ to 1.23; 6 studies, 1175 participants; $1^{2}=33 \%$; low-certainty evidence; Analysis 1.2; Figure 5). The GRADE rating of the evidence for depression was downgraded twice to low certainty due to high risk of bias and imprecision. Sensitivity analysis including only studies at low risk of bias for random sequence generation, allocation concealment or length of follow-up did not change the results. 
Figure 5. Forest plot of comparison: 1 Patient-initiated appointment systems versus consultant-led appointment systems, outcome: 1.2 Patient outcomes: depression (HADS lower score = better 0-21) (9-24 months).

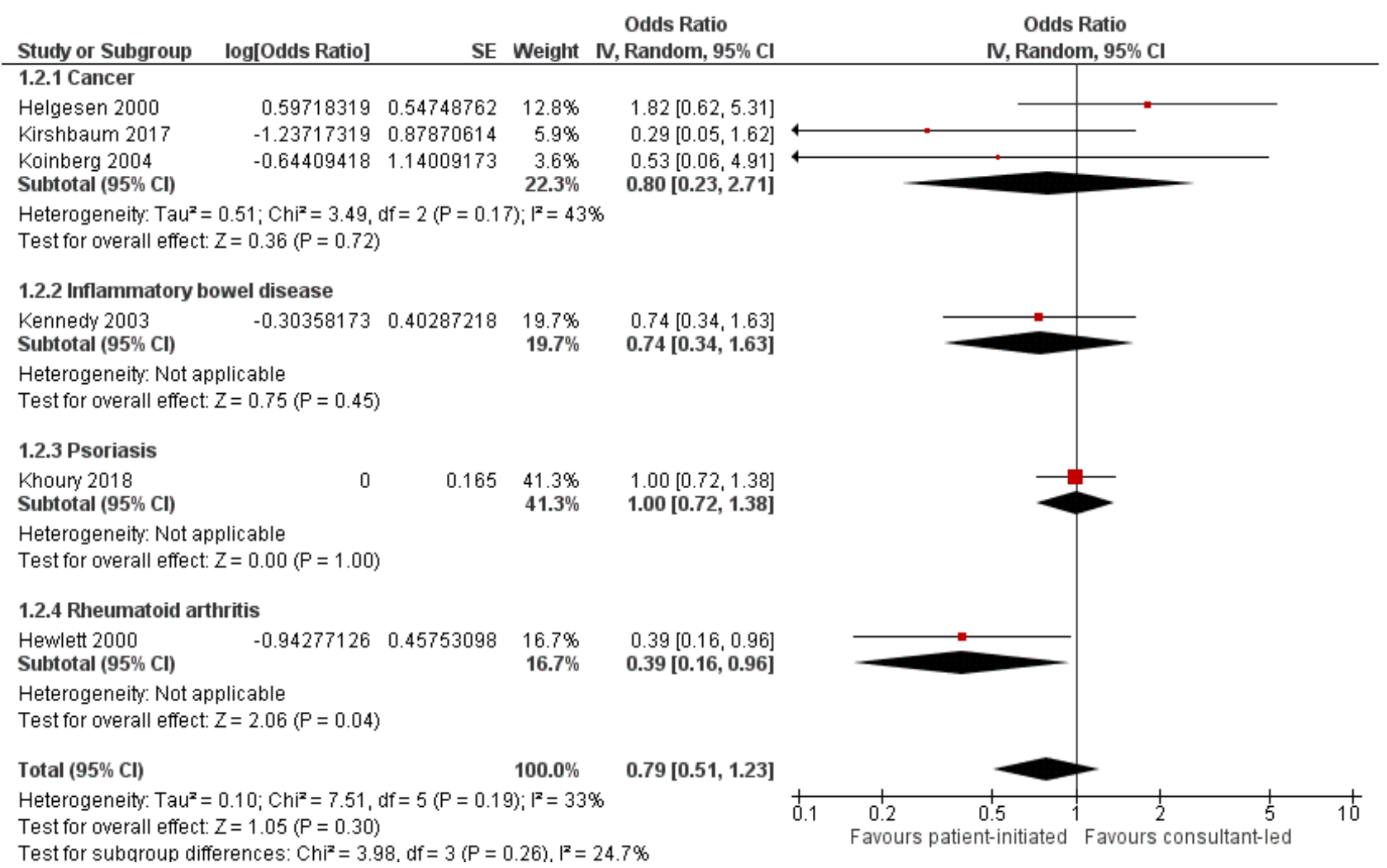

Brown 2002 (61 participants) also reported on depression at 12 months using the same scale. We were unable to retrieve the necessary data to include the study in the meta-analysis but they reported no significant difference in the text between groups (median score: 1 with PIAS versus 2 with consultant-led; $\mathrm{P}=0.232$ ).

\section{Quality of life}

Twelve studies (2232 participants) reported quality of life - four recruited people with cancer, three recruited people with IBD, one recruited people with psoriasis, two recruited people with rheumatoid arthritis, one recruited people with COPD and one recruited people with asthma, each using a different measure of quality of life, with the exception of two IBD studies. For the quality of life measures, higher scores indicate better quality of life. The meta-analysis was conducted using seven of these studies (1486 participants) (Sheppard 2009 Functional Assessment of Cancer Therapy (FACT-B) plus endocrine subscale at 18 months; Lahdensuo 1996 Part 3 St George's Asthma Questionnaire at 12 months; Robinson 2001 IBDQ at 14 months; Primdahl 2012 EQ-5D at 12 months; Kennedy 2003 IBDQ at 12 months; Khoury 2018 Dermatology Life Quality Index (DLQI) at 12 months; Kirshbaum 2017 European Organisation for Research and Treatment of Cancer EORTC QLQ-C30 global scale at 12 months). The results suggest that PIAS may make little or no difference to patient quality of life (SMD $0.12,95 \% \mathrm{Cl}-0.00$ to $0.25 ; 7$ studies, 1486 participants; $\left.\right|^{2}=29 \%$; lowcertainty evidence; Analysis 1.3; Figure 6). The GRADE rating of the evidence for quality of life was downgraded two levels to low due to serious risk of bias and imprecision. Sensitivity analysis including only studies at low risk of bias for random sequence generation, allocation concealment or length of follow-up did not change the results. 
Figure 6. Forest plot of comparison: 1 Patient-initiated appointment systems versus consultant-led appointment systems, outcome: 1.3 Patient outcomes: quality of life (12-18 months).

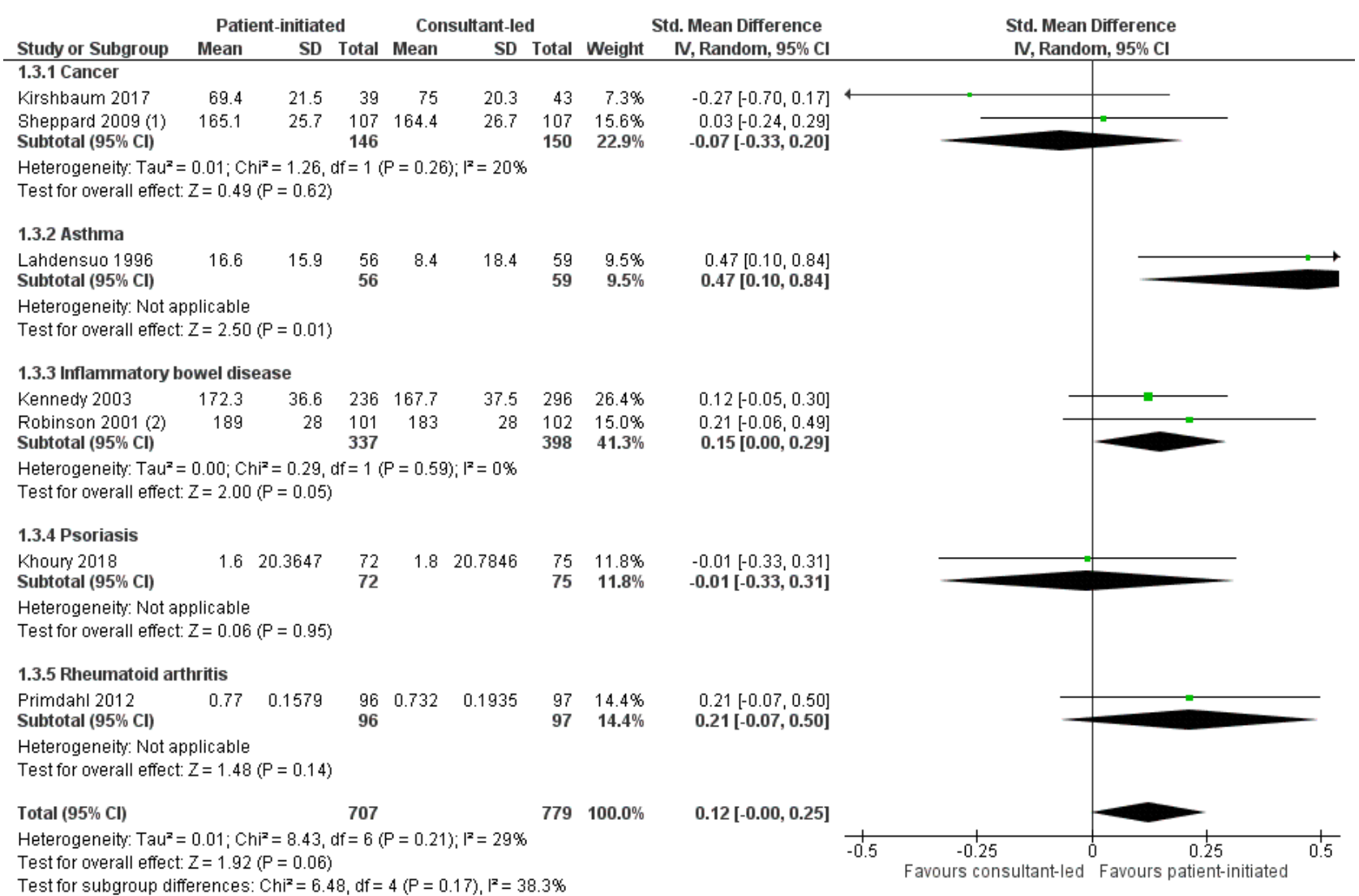

Footnotes

(1) INT and CON scores swapped to account for reverse scoring where in this case lower scores are better

(2) SD for Robinson study is taken from baseline characteristics

Five studies (746 participants) also reported quality of life using differing measures and differing time points, and found similar results in that there appears to be little evidence of differences between the PIAS and consultant-led appointment groups. Brown 2002 reported no significant differences between the PIAS and the consultant-led group using the EORTC QLQ-C30 global scale at 12 months (median score: 11 with PIAS versus 10 with consultantled; no significant difference). Gulliford 1997 did not report results. Hewlett 2000 measured quality of life using the SF-36 at 36 months but presented no data. Williams 2000 reported no significant differences on the UK IBDQ or the SF-36 at 12 months (no total scores provided but all differences in subscales were not significant). Berkhof 2014 reported no significant difference at 24 months on the SF-36 questionnaire (mean change from baseline: 5.2 with PIAS versus -4.8 with consultant-led; $95 \% \mathrm{Cl}-6.7$ to $5.8 ; \mathrm{P}$ $=0.89$ ).

\section{Other health/disease status measurements}

Fifteen studies reported on other health/disease status measurements across all the health conditions; however, data from only two studies were able to be combined in a meta-analysis. These were in studies that recruited people with rheumatoid arthritis (Hewlett 2000; Primdahl 2012). For two of these studies, we ran small meta-analyses on outcomes such as disease activity (Analysis 1.4), self-efficacy (Analysis 1.5), pain (Analysis 1.6) and disability (Analysis 1.7) related to this particular condition. The studies measured disease activity using a visual analogue scale (VAS; $1 \mathrm{~mm}$ to $100 \mathrm{~mm}$ ) and the Disease Activity Scale (DAS) where lower scores are better (a score of 5.1 or more implies active disease, less than 3.2 low disease activity, and less than 2.6 remission; at 24 months). Disease activity is probably slightly reduced in the PIAS group compared with the consultant-led group (SMD $-0.21,95 \% \mathrm{Cl}-0.41$ to $-0.01 ; 2$ studies, 375 participants; $\left.\right|^{2}$ $=0 \%$; moderate-certainty evidence), but this was unlikely to be clinically significant where for the DAS a persistent reduction in score of 1.2 from the original score is required to allow continuation of treatment (NRAS 2020). Fredriksson 2016 also used DAS to measure disease activity and found no significant differences between the PIAS group and the consultant-led group at 18 months (mean change from baseline: 0.24 with PIAS versus 0.59 with consultant-led, $95 \% \mathrm{Cl}-0.01$ to $0.91 ; \mathrm{P}=0.055$ ).

The results regarding self-efficacy measured using the Arthritis SelfEfficacy Scales (ASES; higher scores are better - range 0 to 100) suggest self-efficacy is probably slightly increased in PIAS group compared with the consultant-led group at 24 months (MD 4.95, $95 \% \mathrm{Cl} 0.57$ to $9.34 ; 2$ studies, 375 participants; $12=20 \%$; moderatecertainty evidence), but that the difference may not be clinically significant (minimal clinically important difference 8.5 on ASES; Park 2019). 
The results regarding pain (measured using VAS at 12 months where lower scores are better $1 \mathrm{~cm}$ to $10 \mathrm{~cm}$ ), suggest PIAS probably slightly reduces pain in comparison to consultant-led appointment groups (MD $-0.71,95 \% \mathrm{Cl}-1.17$ to $-0.26 ; 2$ studies, 375 participants; $1^{2}=46 \%$; moderate-certainty evidence), but that the difference may not be clinically significant (minimal clinically important difference $-1.19 \mathrm{~cm}$ Kitchen 2013). Fredriksson 2016 also measured pain using VAS and found no differences (median change from baseline: -3 (IQR -13 to 5 ) with PIAS versus -4 (IQR -18 to 8 ) with consultant-led; 1 study, 131 participants; $P=0.75$ ).

The results regarding disability (measured using Health Assessment Questionnaire (HAQ); score range 0 to 3) where lower scores are better) suggest there is probably little or no difference between PIAS and consultant-led appointment groups on disability scores at 12 months (MD $-0.06,95 \% \mathrm{Cl}-0.19$ to $0.06 ; 2$ studies, 375 participants; $1^{2}=0 \%$; moderate-certainty evidence). The minimal clinically important difference on the HAQ is 0.22 (Kitchen 2013). Fredriksson 2016 also measured disability using the HAQ and found no significant differences between the PIAS and the consultant-led group in the MD since baseline at 18 months (median change from baseline: -0.12 (IQR -0.25 to 0.13 ) with PIAS versus -0.11 (IQR -0.25 to 0.12 ) with consultant-led; $P=0.91$ ). The GRADE of evidence for these studies was downgraded once to moderate due to serious risk of bias in these studies.

The remaining measures of disease-specific and other outcomes of interest reported by individual studies can be found in Analysis 1.14; Analysis 1.15; Analysis 1.16; Analysis 1.17; Analysis 1.18; and Analysis 1.19). A brief summary of these outcomes follows.

Berkhof 2014 described three additional COPD and respiratory symptom outcomes which reported no differences from baseline to 24-month follow-up for the PIAS or the consultant-led groups, and no difference in the time it took to experience an exacerbation of the condition between the PIAS and consultant-led groups (Analysis $1.14 ; \mathrm{P}=0.40$ ).

Seven additional outcomes were reported for cancer (Analysis 1.15). Gulliford 1997 reported that the proportion of participants reassured with the service at 16 months was slightly higher for the consultant-led group (94\%) than the PIAS group (88\%); Helgesen 2000 found that the proportion of participants reporting the service inaccessible by telephone at 36 months was slightly higher for the PIAS group than the consultant-led group (RR 1.18, 95\% Cl 0.46 to 3.03); Jeppesen 2018 reported fear of cancer recurrence at 10 months was slightly higher in the PIAS group in comparison to the consultant-led group $(P=0.02)$, but also that clinical fear of recurrence at 10 months showed no difference between the groups $(P=0.89)$; Koinberg 2004 reported on the accessibility of the service by telephone at 60 months but suggested contrasting evidence to that of Helgesen 2000 by finding little or no difference between the groups; Sheppard 2009 reported no substantial differences between the PIAS and the consultant-led groups on fear of recurrence at 18 months $(P=0.066)$ or the proportion of people feeling isolated $(P=0.245)$.

Five studies reported additional outcomes for IBD (Analysis 1.16): Kennedy 2003 found participants in the PIAS group compared to the consultant-led group were more likely to feel enabled after their initial consultation (MD $0.026,95 \% \mathrm{Cl} 0.12$ to 1.68 ) and more likely to make appointments for themselves (MD 2.70, 95\% Cl 1.63 to 4.46; P $<0.001$ ), with little difference in the delay before starting treatment between the two groups (MD 0.95, 95\% $\mathrm{Cl}-0.52$ to 0.49 ). Conversely, Robinson 2001 reported that the time to symptom treatment was substantially longer for the consultant-led group (mean 49.6 hours) in comparison to the PIAS group (mean 14.8 hours; $\mathrm{P}<0.0001$ ), they also reported that the cost to the patient at 14 months was considerably less in the PIAS group (mean GBP 0.86) compared to the consultant-led group (mean GBP 8.92; $\mathrm{P}<0.0001$ ).

Khoury 2018 reported on four additional outcomes for psoriasis (Analysis 1.17). At 12 months, there was little difference between PIAS and consultant-led groups in missed laboratory tests (MD $0.10,95 \% \mathrm{Cl}-0.20$ to 0.18 ) and disease activity (MD $-0.24,95 \%$ $\mathrm{Cl}-0.84$ to 0.36 ). Whereas missed medication collection at 12 months happened more frequently in the PIAS group compared to the consultant-led group (MD $-0.10,95 \% \mathrm{Cl}-0.024$ to -0.04 ) and changes in medication at 12 months happened more frequently in the consultant-led group (20.6\%) in comparison to the PIAS group $(6.8 \% ; \mathrm{P}<0.001)$.

Two studies reported 10 additional outcomes for rheumatoid arthritis (Analysis 1.18). There was no substantial difference for confidence in care, general health, number of swollen joints, number of tender joints and C-reactive protein levels between baseline and follow-up at 18 months for the PIAS and consultantled groups; however, the number of cases where treatment was changed $(P=0.0002)$ and the erythrocyte sedimentation rate differed substantially $(P=0.03)$ between the two groups (Fredriksson 2016). Hewlett 2000 reported that participants in the PIAS group were more likely to be confident with their interventions than those in the consultant-led group $(P<0.01)$, but found little difference in the change from baseline in terms of feelings of helplessness in the two groups.

For asthma, Lahdensuo 1996 reported on lung function and found no differences between the PIAS and consultant-led groups (Analysis 1.19). This study also reported a difference in the number of days off work with participants in the PIAS group taking fewer days off work (mean 2.8 SD 0 to 62) than those in the consultant-led group (mean 4.8, SD 0 to $27 ; \mathrm{P}=0.02$ ).

The data available for these outcomes were variable and incomplete, which makes it difficult to draw these results together and interpret them in a way that might be useful for the reader.

\section{Service utilisation (contacts)}

Sixteen studies reported service utilisation in terms of appointments or telephone calls (contacts) with various healthcare professionals. The results suggest there may be little or no difference in service utilisation (including hospital appointments, referrals, telephone calls, GP visits, nurse visits, other outpatient contacts, e.g. occupational therapist, physiotherapist, podiatrist, orthopaedic surgeon, orthotics, and tests) in terms of contacts with health professionals/services between the PIAS and consultant-led appointment groups at 12 to 60 months (range 0.68 to 3.83 across the studies; median rate ratio 1.11 , IQR 0.93 to $1.37 ; 15$ studies, 3348 participants; low-certainty evidence). Each study included different elements of service contact in their data, and there may be some expectation that contact might vary between health conditions (see Analysis 1.9 for details). We downgraded the evidence twice to low certainty due to serious risk of bias and imprecision in these studies. The rate ratio does not account for clusters of events/ contacts within the same person. Berkhof 2014 (100 participants) 
could not be included in Analysis 1.9 as we were unable to obtain the appropriate data but their results suggest the GP was visited less frequently in the PIAS compared to the consultant-led group (median number of visits: 4 (range 0 to 32) with PIAS versus 5 ( range 0 to 20) with consultant-led; $P=0.01$ ); the pulmonologist was visited similarly in each group (median number of visits: 3 (range 0 to 17) with PIAS versus 3 (range 0 to 13 ) with consultant-led; $P=0.82$ ); and the pulmonary nurse practitioner was visited more often in the PIAS compared to the consultant-led group (median number of visits: 1 (range 0 to 14) with PIAS versus 0 (range 0 to 4 ) with consultant-led; $P=0.003)$

Two studies (599 participants) report on missed appointments one recruited people with IBD (Kennedy 2003), and one recruited people with psoriasis (Khoury 2018). The results suggest missed appointments may be slightly reduced in the PIAS group compared with the consultant-led group (MD $-0.27,95 \% \mathrm{Cl}-0.42$ to $-0.12 ; 2$ studies, 599 participants; $\mathrm{I}^{2}=0 \%$; low-certainty evidence; Analysis 1.11). The results were downgraded due to serious risk of bias and imprecision (wide $\mathrm{Cls}$ ).

\section{Service utilisation (costs)}

Eight studies reported service utilisation in terms of financial costs. We do not know if service utilisation (costs) are reduced in the PIAS compared to the consultant-led appointment groups as there is very low-certainty evidence (8 studies, 2235 participants). Although six of the eight studies reported reduced costs per patient-year in the PIAS group compared with the consultant-led group, the effect is not certain as each study included different elements of service costs in their data, data were presented in different currencies, and there may be some expectation that service costs will vary between health conditions and locations (see Analysis 1.10 for details). The evidence was downgraded three times due to serious risk of bias (due to incomplete data), serious indirectness (as different currencies and levels of costs reported across studies) and serious imprecision.

\section{Adverse events}

Seven studies (1819 participants) reported adverse events. Five studies (1202 participants) reported relapse or exacerbations or recurrences of the condition (Berkhof 2014; Kennedy 2003; Koinberg 2004; Robinson 2001; Sheppard 2009). We were able to meta-analyse data from three studies on relapse occurrence (Kennedy 2003; Koinberg 2004; Robinson 2001). The results suggest that the intervention may make little or no difference to relapses between the PIAS group and the consultant-led group at 12 to 60 months (MD $-0.20,95 \% \mathrm{Cl}-0.54$ to $0.14 ; 3$ studies, 888 participants; $\mathrm{I}^{2}=67 \%$; low-certainty evidence; Analysis 1.12).

Two studies (314 participants) reported relapse within cancer and COPD. Sheppard 2009 reported no significant differences in the percentage of patients with cancer recurrence between the PIAS group and the consultant-led group at 18 months (rate of recurrence was $4 \%$ in both groups). Berkhof 2014 reported no significant difference in the number of patients with at least one exacerbation of COPD between the PIAS group and the consultantled group at 24 months (38.8\% with PIAS versus $31.4 \%$ with consultant-led; $P=0.44$ ). The GRADE of evidence for these studies was downgraded twice to low certainty due to serious risk of bias and imprecision (wide $\mathrm{Cls}$ ) in these studies.
Two studies (315 participants) reported other adverse events and use of other drugs to assist the condition (Lahdensuo 1996; Primdahl 2012). Only one study (122 participants) reported other adverse events such as use of antibiotics and use of prednisolone (Lahdensuo 1996). This study found that people with asthma within the PIAS group were significantly less likely to report use of other drugs at 12 months than those in consultant-led appointment group (adverse events: 0.6 with PIAS versus 2.1 with consultant-led; $95 \% \mathrm{Cl} 0.9$ to $2.1 ; \mathrm{P}<0.0001$ ). Primdahl 2012 report no significant differences in the number of adverse effect alerts between people with rheumatoid arthritis in the PIAS group (mean 1.19) and the consultant-led group (mean 1.61) at 24 months.

\section{Secondary outcomes}

\section{Other service utilisation}

None of the studies reported this separately from the 'Service utilisation (contacts)' and 'Service utilisation (costs)' recorded above.

\section{Patient satisfaction}

Twelve studies (2950 participants) reported patient satisfaction with (and acceptability of) the intervention (see Analysis 1.13 and Analysis 1.8 where higher scores indicate better satisfaction). The results were unclear about any differences the intervention may make to patient satisfaction as the certainty of the evidence was low. Of the four studies that recruited people with rheumatoid arthritis (796 patients) (Fredriksson 2016; Goodwin 2016; Hewlett 2000; Primdahl 2012), meta analysis was conducted on two studies (375 participants) (Hewlett 2000; Primdahl 2012) and suggest that PIAS had little or no effect on satisfaction compared to the consultant-led system at 12 to 24 months (SMD 0.05, 95\% Cl 0.41 to 0.52 ; 2 studies, 375 participants; $I^{2}=81 \%$; low-certainty evidence). A third study (131 participants) (Fredriksson 2016) could not be included in the analysis but also reported little or no difference between the groups. The fourth study ( 290 participants) Goodwin 2016 also could not be included in the analysis but reported a significant difference $(p=0.002)$ between the groups with greater satisfaction with the service in the PIAS compared to the consultant-led system. We downgraded the evidence twice to low certainty due to serious risk of bias and indirectness.

The results across other conditions were also variable (see Analysis 1.13 for more details for each study). For example, of the four studies reporting patient satisfaction in people with cancer (921 patients), one reported that the consultant-led group had greater satisfaction than the PIAS group though significance was not reported (mean: 122 (SE 91.6) with PIAS versus 130 (SE 98.9) with consultant-led; 264 participants at 60 months; Koinberg 2004). Of the three studies reporting patient satisfaction in people with IBD, two reported that the PIAS group may have greater satisfaction than the consultant-led group (Kennedy 2003: mean: 54.6 (SD 8.5) with PIAS versus 53.6 (SD 9.1) with consultant-led; $95 \% \mathrm{Cl}-3.67$ to 6.03; $\mathrm{P}=0.62$; Williams 2000: mean: 69 (SE 85) with PIAS versus 4 (SE 41) with consultant-led; $P<0.01 ; 280$ participants at 12 to 24 months) but with varying levels of significance. One study reporting patient satisfaction in people with psoriasis reported no difference between the PIAS group and the consultant-led group (Khoury 2018: mean: 3.6 (SE 0.1) with PIAS versus 3.5 (SE 0.1) with consultant-led; $\mathrm{P}=0.75 ; 147$ participants at 12 months). 


\section{Clinician (consultant or specialist nurse) satisfaction}

None of the studies reported clinician (consultant or specialist nurse) satisfaction.

\section{Failures of the 'system'}

None of the studies reported outcomes regarding failures of the 'system' (e.g. how long participants are on the PIAS pathway but not using it correctly before the clinical team needs to reinstigate regular follow-up clinics). One study (209 participants) reported safety net failure. Hewlett 2000 defined a safety net failure as an increase of more than $20 \%$ of the clinical experience of pain, disease activity or disability as recorded on the relevant scales. This study reported no significant differences in the number of safety net failures between the people with rheumatoid arthritis in the PIAS group $(26.5 \%)$ and the consultant-led group (28.9\%) at 24 months.

\section{DISCUSSION}

\section{Summary of main results}

In this review of PIASs, we included 17 studies reported in 26 papers. The studies involved 3854 adults all enrolled in a PIAS or in consultant-led appointment systems across six conditions: cancer, rheumatoid arthritis, IBD, asthma, psoriasis and COPD. Study follow-up ranged from 12 to 72 months, with the most commonly reported time points (those used in meta-analyses) being 12 to 24 months.

The review provides mainly low-certainty evidence for PIASs on a number of outcomes, as well as some less-frequently reported outcomes of interest (Summary of findings for the main comparison). The results of meta-analyses provide some indication of the likely effect; however, the likelihood that it will be substantially different is high. The results suggest PIAS may have little or no impact on patient anxiety, depression and quality of life. For other health disease status measurements, such as disease activity and pain, results suggest these are probably slightly reduced in the PIAS group compared with the consultant-led group. There is probably little or no impact on disability between PIAS and consultant-led groups, and self-efficacy is probably slightly increased in the PIAS group compared with the consultant-led group. Other aspects of disease status and experience appear to show little or no difference between PIAS and consultant-led appointment systems.

The results for service utilisation (contacts) are mixed with no clear indication of reduced or increased service contact. Linked to this, results also suggest missed appointments may be slightly reduced in the PIAS group compared with the consultant-led group. We do not know if service utilisation (costs) could be reduced in the PIAS compared to the consultant-led appointment groups due to the low-certainty evidence and because we did not use a currency convertor to establish a common currency, this decision was made in part due to the fact the studies did not report consistently on the services they included in their costs which also made the evidence less comparable across studies.

The results for adverse events suggest people within the PIAS group may be no more or less likely to report a relapse or recurrence of their condition or other adverse effects compared with the consultant-led group. Evidence from one study suggests people with asthma within the PIAS group were significantly less likely to report use of other drugs at 12 months than those in consultant-led appointment group but this is based on low-certainty evidence.

It is also uncertain whether PIAS improve patient satisfaction because the certainty of evidence is low, each study used different questions to collect their data at different time points and across different health conditions. This may also reflect the perceived severity of the condition or the ease with which symptoms can be identified.

None of the studies reported failures of the system other than safety net failure or clinician (consultant or specialist nurse) satisfaction.

\section{Overall completeness and applicability of evidence}

This review highlights a few issues concerning the completeness and applicability of the evidence.

First, we found few published studies investigating this question across differing health conditions. We suspect that much of this type of service change may occur without evaluations being published. This may mean there is some form of publication bias to be considered or may mean that these types of service changes are evolving (or not) within the clinical context with only local internal evaluations being conducted.

Second, we noticed a distinct lack of studies from outside Europe. This might reflect the differing healthcare system structures in place internationally or a lack of reporting of this type of system change. It may also reflect how funding of research trials in the UK and Europe is geared towards randomised trials of service delivery interventions. This means the review may have a good deal of applicability to service designs such as (and similar to) the UK NHS.

Third, while the mean age range of the people involved in these studies may reflect the population who are largely affected by longterm conditions, it may also reflect bias in whom the clinicians might also trust to know and manage their own condition. This implies that this type of appointment system may not be appropriate for all patients, particularly those with a new diagnosis (although this has not been studied in the research included in this review).

Fourth, variation in the quality of reporting of the intervention makes it difficult to know how to reliably interpret the findings of the review. For example, the results of this review suggest great variability in satisfaction of patients with the intervention. This difference could be due to: poor reporting of the levels of satisfaction between PIAS and consultant-led appointment groups; a real difference between those with rheumatoid arthritis and those with different types of cancer (suggesting that the PIAS system may not work for all long-term chronic conditions); different tools/ bespoke sets of questions being used to ask patients about their satisfaction with the service; or that particular elements of the intervention have been used or are missing from those studies. The reporting of interventions in detail is important, yet difficult with word restrictions placed on peer review publications and with authors potentially being uncontactable at the time of the review.

\section{Certainty of the evidence}

The overall certainty of the evidence included in this review ranged mainly from low to very low according to the GRADE classification (Higgins 2011). This was due to the poor reporting of the studies, 
but even where authors were contacted, it was not always possible to gain clarification of the study details, leading to a substantial amount of uncertainty within the existing evidence surrounding this intervention. For example, the evidence around anxiety, depression and quality of life was downgraded to low certainty due to the risk of bias identified within studies and the wide Cls presented in the analyses. Service utilisation (contacts) evidence was downgraded to low certainty due to serious indirectness and difficulties assessing the consistency and precision of the results. Service utilisation (costs) evidence was downgraded to very-low certainty due to risk of bias across studies, serious indirectness and serious imprecision. The evidence around adverse events was downgraded to low certainty due to risk of bias across studies and serious consistency and imprecision and the evidence for patient satisfaction was downgraded to low certainty due to risk of bias, the indirectness related to how satisfaction was measured across studies, and due to consistency and precision being difficult to assess.

This made the details of data analysis and attrition inconsistent and difficult to follow. When clearly reported, random sequence generation and allocation concealment were areas of low risk of bias, but for some studies this remained unclear. Blinding of the participants and personnel would have not been possible with this type of intervention.

\section{Potential biases in the review process}

This review reduced the likelihood of potential biases by following the comprehensive guidelines set out in the Cochrane Handbook for Systematic Reviews of Interventions (Higgins 2011). The review outcomes were also broad so that we could be sure to capture all the relevant research evidence. The review did not include research conducted with children and did not include studies which referred to patients 'self-management' without a description of the intervention as in the Description of the intervention.

\section{Agreements and disagreements with other studies or reviews}

The previous reviews in this area attempted to incorporate a wider range of study design, but found only nine studies to include between them and these studies were all based in the UK (Whear 2013a; Whear 2013b). Despite these differences, our review reports similar findings, with uncertainty remaining a strong message throughout.

\section{AUTHORS' CONCLUSIONS}

\section{Implications for practice}

Overall, this review provides low-certainty evidence that patientinitiated appointment systems may have little or no impact on the anxiety, depression and quality of life of people with chronic conditions in secondary care. Other aspects of disease status and experience also appear to show little or no difference between patient-initiated and consultant-led appointment systems. The impact of patient-initiated appointment systems on service utilisation (contacts and costs) and adverse events was uncertain compared to consultant-led appointment systems. There is also some uncertainty as to the level of satisfaction experienced by patients using this mode of care. This could be seen positively as some evidence of no harm; however, clinicians should be cautious in implementing this system within their care practices and should be vigilant about which patients may benefit and be confident and satisfied using the system (both within and across health conditions). Care should be taken to record the impact on service utilisation (including contact with professionals and financial costs) as well as other service/care information, such as the number of appointments not attended and the number of adverse events such as relapses and recurrences.

\section{Implications for research}

Further research in this area would benefit from higherquality, better-reported and larger randomised trials with longer endpoints. These trials would also benefit from standard measurement and reporting of outcomes of common interest such as quality of life, anxiety, depression, satisfaction with the intervention, relapses/recurrences, and service utilisation contacts and costs, as well as more consistent reporting of adverse events or failures of the system.

Future research might also consider whether particular aspects of the intervention are associated with effectiveness such as the role of the general practitioner (GP), use of extra educational material or care management plans within the intervention and the content of the initial consultation. Future research might also consider benefits to particular populations such as those in more rural/remote areas and those who have difficulty attending appointments due to disability, access to transport or other lack of support services. Differences in service use or effectiveness between population characteristics such as gender, age, and length of time living with their condition and type of condition would also be worth exploring. Further investigation of all these components and the mechanism of action will help to structure and maintain a sustainable appointment system that is acceptable to patients and health professionals. New areas of 'patient-initiated care' are also developing (e.g. NCT02577224; Schougaard 2019), and would be worth considering in the future of patient-initiated care and experience across different conditions.

\section{ACKN OWLEDGEMENTS}

We would like to acknowledge the helpful feedback and comments from the protocol peer reviewers Craig Ramsay, Leora Horwitz, Megan Prictor and Sasha Shepperd, and the help and advice from Michelle Fiander (information specialist), JC Han and Denise O'Connor. We thank the peer reviewers Sasha Shepperd, Craig Ramsay, Paul Miller, Yvonne Zurynski, Polina Putrik, Jenny Negus and Alison Campbell, and Cochrane funding to the Effective Practice and Organisation of Care Group. The views and opinions expressed herein are those of the authors and do not necessarily reflect those of the Systematic Reviews Programme, National Institute for Health Research, National Health Service or the Department of Health.

This report is independent research supported by the National Institute for Health Research Applied Research Collaboration South West Peninsula. The views expressed in this publication are those of the authors and not necessarily those of the National Institute for Health Research or the Department of Health and Social Care. 


\section{RE F E R E N C E S}

\section{References to studies included in this review}

Berkhof 2014 \{published data only\}

Berkhof F, Hesselink A, Uil S, Kerstjens H, Van Willem J. A 2 year follow up randomized pilot study of a care on demand system in COPD patients. European Respiratory Journal 2013;42(108):1163-70.

* Berkhof F, Hesselink A, Vaessen D, Uil S, Kerstjens H, van den Berg J. The effect of an outpatient care on-demand system on health status and costs in patients with COPD. A randomized trial. Respiratory Medicine 2014;108(8):1163-70.

Brown 2002 \{published data only\}

Brown L, Payne S, Royle G. Patient initiated follow up of breast cancer. Psycho-Oncology 2002;11:346-55.

\section{Fredriksson 2016 \{published data only\}}

Fredriksson C, Ebbevi D, Waldheim E, Lindblad S, Ernestam S. Patient-initiated appointments compared with standard outpatient care for rheumatoid arthritis: a randomised controlled trial. RMD Open 2016;2:1-7.

\section{Goodwin 2016 \{published data only\}}

Goodwin V, Paudyal P, Perry M, Day N, Hawton A, Gericke C, et al. Implementing a patient-initiated review system for people with rheumatoid arthritis: a prospective, comparative service evaluation. Journal of Evaluation in Clinical Practice 2016;22(3):439-45.

\section{Gulliford 1997 \{published data only\}}

Gulliford T, Opomu M, Wilson E, Hanham I, Epstein R. Popularity of less frequent follow up for breast cancer in randomised study: initial findings from the hotline study. BMJ 1997;314:174-81.

\section{Helgesen 2000 \{published data only\}}

Helgesen F, Andersson S, Gustafsson O, Varenhorst E, Goben B, Carnock S, et al. Follow-up of prostate cancer patients by ondemand contacts with a specialist nurse. Scandinavian Journal of Urology and Nephrology 2000;34:55-61.

\section{Hewlett 2000 \{published data only\}}

Hewlett S. Patient initiated outpatient follow up in rheumatoid arthritis: six year randomised controlled trial. Health Economics 2004;13:1167-80.

* Hewlett S, Kirwan J, Pollock J, Mitchell K, Hehir M, Blair P, et al. Patient initiated outpatient follow up in rheumatoid arthritis: six year randomised controlled trial. BMJ 2005;330:171-5.

Hewlett S, Mitchell K, Haynes J, Paine T, Korendowych E, Kirwan J. Patient-initiated hospital follow-up for rheumatoid arthritis. Rheumatology 2000;39:990-7.

Kirwan J, Mitchell K, Hewlett S, Hehir M, Pollock J, Memel D, et al. Clinical and psychological outcome from a randomized controlled trial of patient-initiated direct-access hospital followup for rheumatoid arthritis extended to 4 years. Rheumatology 2003;42:422-6.

\section{Jeppesen 2018 \{published data only\}}

Jeppesen MM, Jensen PT, Hansen DG, Christensen RD, Mogensen 0 . Patient-initiated follow up affects fear of recurrence and healthcare use: a randomised trial in early-stage endometrial cancer. BJOG 2018;125(13):1705-14.

\section{Kennedy 2003 \{published data only\}}

* Kennedy A, Nelson E, Reeves D, Richardson G, Roberts C, Robinson $A$, et al. A randomised controlled trial to assess the impact of a package comprising a patient-orientated, evidencebased self-help guidebook and patient-centred consultations on disease management and satisfaction in inflammatory bowel disease. Health Technology Assessment 2003;7(28):1-126.

Kennedy AP, Nelson E, Reeves D, Richardson G, Roberts C, Robinson $A$, et al. A randomised controlled trial to assess the effectiveness and cost of a patient orientated self management approach to chronic inflammatory bowel disease. Gut 2004;53:1639-45

Khoury 2018 \{published data only\}

Khoury LR, Møller T, Zachariae C, Skov L. A prospective 52week randomized controlled trial of patient-initiated care consultations for patients with psoriasis. British Journal of Dermatology 2018;179(2):301-8.

Kirshbaum 2017 \{published data only\}

Kirshbaum MN, Dent J, Stephenson J, Topping AE, Allinson V, McCoy M, et al. Open access follow-up care for early breast cancer: a randomised controlled quality of life analysis. European Journal of Cancer Care 2017;26(4):e:12577.

Koinberg 2004 \{published data only\}

Koinberg I, Engholm G, Genell A, Holmberg L. A health economic evaluation of follow-up after breast cancer surgery: results of an RCT study. Acta Oncologica 2009;48:99-104.

* Koinberg I, Fridlund B, Engholm G, Holmberg L. Nurse-led follow-up on demand or by a physician after breast cancer surgery: a randomised study. European Oncology Nursing Society 2004;8:109-17.

\section{Lahdensuo 1996 \{published data only\}}

Lahdensuo A, Haahtela T, Herrala J, Kava T, Kiviranta K, Kuusisto $P$, et al. Randomised comparison of guided self management and traditional treatment of asthma over one year. BMJ 1996;312:748-52.

\section{Primdahl 2012 \{published data only\}}

Primdahl J, Horn HC, Petersen R, Horslev-Petersen K. Clinical and radiological outcome in outpatients with rheumatoid arthritis followed by medical, nursing or shared care-a two year randomised controlled trial. Annals of the Rheumatic Disease 2013;71:92.

* Primdahl J, Sorensen J, Horn H, Petersen R, HorslevPetersen K. Shared care or nursing consultations as an alternative to rheumatologist follow-up for rheumatoid arthritis outpatients with low disease activity - patient outcomes from 
a 2-year, randomised controlled trial. Annals of the Rheumatic Diseases 2014;73:357-64.

Primdahl J, Wagner L, Holst R, Horslev-Petersen K, AMBRA study group. The impact on self-efficacy of different types of follow-up care and disease status in patients with rheumatoid arthritis - a randomized trial. Patient Education and Counseling 2012;88:121-8.

Sørensen J, Primdahl J, Horn H, Hørslev-Petersen K. Shared care or nursing consultations as an alternative to rheumatologist follow-up for rheumatoid arthritis outpatients with low disease activity: cost-effectiveness based on a twoyear randomized trial. Scandinavian Journal of Rheumatology 2015;44:13-21.

\section{Robinson 2001 \{published data only\}}

Robinson A, Thompson D, Wilkin D, Roberts C. Guided selfmanagement and patient-directed follow-up of ulcerative colitis: a randomised trial. Lancet 2001;358:976-81.

\section{Sheppard 2009 \{published data only\}}

Sheppard C, Higgins B, Wise M, Yiangou C, Dubois D, Kilburn S. Breast cancer follow up: a randomised controlled trial comparing point of need access versus routine 6-monthly clinical review. European Journal of Oncology Nursing 2009;13:2-8.

\section{Williams 2000 \{published data only\}}

Williams J, Cheung W, Russell I, Cohen D, Longo M, Lervy B. Open access follow up for inflammatory bowel disease: pragmatic randomised trial and cost effectiveness study. BMJ 2000;320:544-8.

\section{References to studies excluded from this review}

\section{Adams 2009 \{published data only\}}

Adams N, Sands A. Patient versus practitioner-initiated follow-up for rheumatoid arthritis. European Journal of Pain 2009;13:S132.

\section{Arnaud 1997 \{published data only\}}

Arnaud JP, Cervi C, Bergamaschi R, Tuech JJ. Contribution of cancerology follow-up in patients undergoing surgery for colorectal cancer. Journal de Chirurgie 1997;134:45-50.

\section{Booth 2001 \{published data only\}}

Booth H, Goodburn A, Miller R, Scott G. Performance of a dedicated open access multidisciplinary tuberculosis (TB) clinic. Thorax 2001;56:57-8.

\section{Bourbeau 2003 \{published data only\}}

Bourbeau J, Julien M, Maltais F, Rouleau M, Beaupre A. Reduction of hospital utilisation in patients with chronic obstructive pulmonary disease: a disease-specific selfmanagement intervention. Archives of Internal Medicine (Chicago, Ill. : 1908) 2003;163:585-91.

\section{Coenen 2017 \{published data only\}}

Coenen S, Weyts E, Vermeire S, Ferrante M, Noman M, Ballet V, et al. Effects of introduction of an inflammatory bowel disease nurse position on the quality of delivered care. European Journal of Gastroenterology and Hepatology 2017;29(6):646-50.

Dent 2011 \{published data only\}

Dent J, Topping A, Ferguson C, Stephenson J, McCoy M, Allinson V, et al. To follow up or not? A new model of supportive care for early breast cancer. Journal of Clinical Oncology 2011;1:S1.

\section{Emery 2014a \{published data only\}}

Emery J, Schofield P, Jefford M, King M, Pirotta M, Hayne D, et al. The ProCare trial: a phase II randomised controlled trial of shared care for follow-up of men with prostate cancer. AsiaPacific Journal of Clinical Oncology 2014;10:157.

\section{Emery 2014b \{published data only\}}

Emery J, Doorey J, Jefford M, King M, Pirotta M, Hayne D, et al. Protocol for the ProCare trial: a phase II randomised controlled trial of shared care for follow-up of men with prostate cancer. BMJ Open 2014;4:1-10.

\section{Emery 2017 \{published data only\}}

Emery JD, Jefford M, King M, Hayne D, Martin A, Doorey J, et al. ProCare trial: a phase II randomized controlled trial of shared care for follow-up of men with prostate cancer. BJU International 2017;119(3):381-9.

\section{Fournier 2015 \{published data only\}}

Fournier J, Rainville A, Ingram J, Heale R. Implementation of an advanced access scheduling system in primary healthcare: one clinic's experience. Healthc Q 2015;18:60-4.

\section{Hesselink 2011 \{published data only\}}

Hesselink A, Uil S, Kerstjens H, Van Den Berg JW. Effectiveness of an outpatient care on-demand system in patients with chronic obstructive pulmonary disease: a randomized controlled pilot study. Chest 2011;140:4.

\section{Hewlett 2005 \{published data only\}}

Hewlett S. Implementation of patient-initiated review in rheumatoid arthritis. Developing Practice Improving Care : Dissemination Series 2005;3:3.

\section{Lawlor 2009 \{published data only\}}

Lawlor M, Kealy S, Agnew M, Korn B, Quinn J, Cassidy C, et al. Early discharge care with ongoing follow-up support may reduce hospital readmissions in COPD. International Journal of COPD 2009;4:55-60.

\section{McBain 2014a \{published data only\}}

McBain H, Shipley M, Moore S, Olaleye A, Hirani S, Newman SP. A self-monitoring and patient-initiated follow-up service for patients with rheumatoid or psoriatic arthritis: a randomized controlled trial. Rheumatology 2014;53:i77.

\section{McBain 2014b \{published data only\}}

McBain H. The Development and Evaluation of a SelfMonitoring and Patient-Initiated Follow-up Service for People with Rheumatoid or Psoriatic Arthritis on Methotrexate [PhD thesis]. London (UK): City University, 2014. 
McBain 2015 \{published data only\}

McBain H, Shipley M, Olaleye A, Moore S, Newman S. A patient-initiated DMARD self-monitoring service for people with rheumatoid or psoriatic arthritis on methotrexate: a randomised controlled trial. Annals of the Rheumatic Disease 2015; Vol. 75, issue 7:1343-9.

\section{Ndosi 2011 \{published data only\}}

Ndosi M, Lewis M, Hale C, Quinn H, Ryan S, Emery P, et al. A randomised, controlled study of outcome and cost effectiveness for RA patients attending nurse-led rheumatology clinics: study protocol of an ongoing nationwide multi-centre study. International Journal of Nursing Studies 2011;48:995-1001.

Paudyal 2012 \{published data only\}

Paudyal P, Perry M, Child S, Gericke CA. Evaluation of a patient-initiated review system in rheumatoid arthritis: an implementation trial protocol. BMC Musculoskeletal Disorders 2012;13:120

\section{Pope 2005 \{published data only\}}

Pope D, Tipler S, Kirwan J, Hewlett S. Implementing a patient-led service for chronic conditions. Nursing times 2005;101:28-31.

\section{Pope 2014 \{published data only\}}

Pope D. How can patients effectively shape rheumatology service delivery in secondary care?. Rheumatology 2014;53:i7.

\section{Rogers 2004 \{published data only\}}

Rogers A, Kennedy A, Nelson E, Robinson A. Patients' experiences of an open access follow up arrangement in managing inflammatory bowel disease. Quality \& Safety in Health Care 2004;13:374-8.

\section{Sands 2009 \{published data only\}}

Sands A, Adams N. A comparison of patient-initiated versus conventional follow-up for rheumatoid arthritis. Journal of Pain Management 2009;1:391-400.

\section{Schougaard 2019 \{published data only\}}

Schougaard LM, Mejdahl CT, Petersen KH, Jessen A, De Thurah A, Sidenius $P$, et al. Patient-initiated versus fixedinterval patient-reported outcome-based follow-up in outpatients with epilepsy: a pragmatic randomized controlled trial. Journal of Patient-Reported Outcomes 2019;3:61.

\section{References to ongoing studies}

NCT02577224 \{unpublished data only\}

NCT02577224. An RCT of a patient-initiated treatment service for BEB and HFS. clinicaltrials.gov/ct2/show/NCT02577224 (first received 8 May 2015).

\section{Additional references}

Car 2012

Car J, Gurol-Urganci I, de Jongh T, Vodopivec-Jamsek V, Atun R. Mobile phone messaging reminders for attendance at healthcare appointments. Cochrane Database of Systematic Reviews 2012, Issue 7. [DOI: 10.1002/14651858.CD007458]

\section{DerSimonian 1986}

DerSimonian R, Laird N. Meta-analysis in clinical trials. Controlled Clinical Trials 1986;7:177-188.

\section{DoH 2001}

Department of Health (DoH). The expert patient: a new approach to chronic disease management for the 21st century. webarchive.nationalarchives.gov.uk/+/ www.dh.gov.uk/en/Publicationsandstatistics/Publications/ PublicationsPolicyandGuidance/DH_4006801 (accessed 1 October 2013).

\section{EPOC 2015}

Effective Practice, Organisation of Care (EPOC). EPOC Taxonomy, 2015. epoc.cochrane.org/epoc-taxonomy (accessed 1 August 2019).

\section{EPOC 2017a}

Cochrane Effective Practice, Organisation of Care (EPOC). Data collection form. EPOC resources for review authors, 2017. Available from epoc.cochrane.org/epoc-specific-resourcesreview-authors (accessed prior to 19 March 2020).

\section{EPOC 2017b}

Cochrane Effective Practice, Organisation of Care (EPOC). EPOC worksheets for preparing a 'Summary of findings' table using GRADE. EPOC resources for review authors, 2017. Available from epoc.cochrane.org/epoc-specific-resources-review-authors (accessed prior to 19 March 2020).

\section{GRADEpro GDT [Computer program]}

McMaster University (developed by Evidence Prime). GRADEpro GDT. Hamilton (ON): McMaster University (developed by Evidence Prime), 2015.

\section{Guyatt 2008}

Guyatt GH, Oxman AD, Vist G, Kunz R, Falck-Ytter Y, AlonsoCoello P, et al. GRADE Working Group. GRADE: an emerging consensus on rating quality of evidence and strength of recommendations. BMJ 2008;336(7650):924-6.

\section{HES 2010}

HES NHS Information Centre for Health and Social Care. Outpatient data: SHA and provider level analysis 2008-09 and 2009-10. www.hscic.gov.uk/ searchcatalogue? productid $=2805 \& q=\% 22$ hospital +outpatient+activity\%22\&topics $=0 \% 2 \mathrm{fH}$ ospital +care\&sort=Relevance\&size=10\&page=1\#top (accessed December 2012).

\section{Higgins 2011}

Higgins JP, Green S, editor(s). Cochrane Handbook for Systematic Reviews of Interventions Version 5.1.0 (updated March 2011). The Cochrane Collaboration, 2011. Available from handbook.cochrane.org. The Cochrane Collaboration. 


\section{Kirwan 1991}

Kirwan J, Snow S. Which patients see a rheumatologist. British Journal of Rheumatology 1991;30:285-7.

\section{Kitchen 2013}

Kitchen H, Bekker Hansen B, Abetz L, Højbjerre L, StrandbergLarsen M. Patient-reported outcome measures for rheumatoid arthritis: minimal important differences review. ACR/ARHP Annual Meeting; 2013 Oct 25-30; San Diego (CA) 2013.

\section{Liberati 2009}

Liberati A, Altman DG, Tetzlaff J, Mulrow C, Gotzsche PC, Ioannidis JP, et al. The PRISMA statement for reporting systematic reviews and meta-analyses of studies that evaluate health care interventions: explanation and elaboration. PLOS Medicine 2009;6(7):e1000100.

\section{Liu 2010}

Liu N, Ziya S, Kulkarni VG. Dynamic scheduling of outpatient appointments under patient no-shows and cancellations. Manufacturing and Service Operations Management 2010;12(2):347-64

\section{National Audit Office 2014}

National Audit Office. NHS waiting times for elective care in England. www.nao.org.uk/wp-content/uploads/2014/01/ NHS-waiting-times-for-elective-care-in-England-summary.pdf (accessed May 2017).

\section{NHS 2019}

NHS. The NHS long term plan, 2019. www.longtermplan.nhs.uk/ publication/nhs-long-term-plan/ (accessed 19 March 2020).

\section{NRAS 2020}

National Rheumatoid Arthritis Society. The DAS28 score. www.nras.org.uk/the-das28-score (accessed Feb 2020).

\section{Nuffield 2011}

Nuffield Trust. Health and social care bill: second reading, House of Lords. www.parliament.uk/business/news/2011/ october1/health-and-social-care-bill-2nd-reading-/ (accessed 1 October 2013).

\section{Park 2019}

Park I, Oh M-J, Shin S-J. Minimal clinically important differences and correlating factors for the Rowe score and the American Shoulder and Elbow Surgeons score after arthroscopic stabilization surgery for anterior shoulder instability. Arthroscopy 2019;35(1):54-9.

\section{Probert 1993}

Probert C, Jayanthi V, Mayberry J. British gastroenterologists' care profile for patients with inflammatory bowel disease: the need for a patients' charter. Journal of the Royal Society of Medicine 1993;86:271-2.

\section{RCP 2018}

Royal College of Physicians. Outpatients: the future - adding value through sustainability, 2018. www.rcplondon.ac.uk/ projects/outputs/outpatients-future-adding-value-throughsustainability (accessed 19 March 2020).

\section{Reda 2012}

Reda S, Rowett M, Makhoul S. Prompts to encourage appointment attendance for people with serious mental illness. Cochrane Database of Systematic Reviews 2012, Issue 8. [DOI: 10.1002/14651858.CD002085]

\section{Review Manager 2014 [Computer program]}

Nordic Cochrane Centre, The Cochrane Collaboration. Review Manager 5 (RevMan 5). Version 5.3. Copenhagen: Nordic Cochrane Centre, The Cochrane Collaboration, 2014.

\section{Robinson 2010}

Robinson L, Chen R. A comparison of traditional and openaccess policies for appointment scheduling. Manufacturing and Service Operations Management 2010;12(2):330-46.

\section{Rose 2011}

Rose KD, Ross JS, Horwitz LI. Advanced access scheduling outcomes: a systematic review. Archives of Internal Medicine 2011;171(13):1150-9.

\section{Whear 2013a}

Whear R, Abdul-Rahman A-K, Boddy K, Thompson-Coon J, Perry M, Stein K. The clinical effectiveness of patient initiated clinics for patients with chronic or recurrent conditions managed in secondary care: a systematic review. PloS One 2013;8(10):1-11.

\section{Whear 2013b}

Whear R, Abdul-Rahman AK, Thompson-Coon J, Boddy K, Perry MG, Stein K. Patient initiated clinics for patients with chronic or recurrent conditions managed in secondary care: a systematic review of patient reported outcomes and patient and clinician satisfaction. BMC Health Services Research 2013;13:1-12.

\section{WHO 2002}

World Health Organization. Innovative care for chronic conditions: building blocks for action. www.who.int/chp/ knowledge/publications/icccreport/en/ (accessed 1 October 2013).

\section{WHO 2011}

World Health Organization. Noncommunicable diseases country profiles. www.who.int/nmh/publications/ ncd_profiles2011/en/index.html (accessed 1 October 2013).

\section{WHO 2013}

World Health Organization. Chronic diseases. www.who.int/ topics/chronic_diseases/en/ (accessed 1 October 2013).

\section{References to other published versions of this review \\ Whear 2013}

Whear R, Thompson Coon J, Rogers M, Abbott R, Ukoumunne O, Perry MG, et al. Patient-initiated appointment systems for people with chronic conditions in secondary care. Cochrane Database of Systematic Reviews 2013, Issue 12. [DOI: 10.1002/14651858.CD010763] 


\section{CHARACTERISTICS OF STUDIES}

Characteristics of included studies [ordered by study ID]

\section{Berkhof 2014}

\begin{tabular}{|c|c|}
\hline Methods & Individual, single-centre prospective randomised trial, 24 months \\
\hline Participants & $\begin{array}{l}\text { Netherlands; } 1 \text { teaching hospital ( } 100 \text { participants); COPD; } 74 \text { males, } 26 \text { females; mean age } 69 \text { years } \\
\text { CONT, } 69 \text { years INT }\end{array}$ \\
\hline Interventions & $\begin{array}{l}\text { INT }(n=49) \text { : participant could call NP when experienced increase in symptoms such as dyspnoea, } \\
\text { cough, sputum, haemoptysis or thoracic pain. NP then followed protocol designed for study which in- } \\
\text { cluded taking a history from participant to assess urgency; if urgency low, appointment booked with } \\
\text { NP next day, if urgency high, NP could seek advice from pulmonologist and could book appointment } \\
\text { with pulmonologist within next few hours. Safety net - } 1 \text { fixed appointment per year. }\end{array}$ \\
\hline & $\begin{array}{l}\text { CONT ( } n=51 \text { ): consultant- or NP-led (schedule NR/at discretion of pulmonologist), availability of emer- } \\
\text { gency appointments unclear. }\end{array}$ \\
\hline
\end{tabular}

\section{Outcomes}

COPD symptoms scores: 6, 12, 24 months (CCQ)

Respiratory symptoms: 6, 12, 24 months (SGRQ)

Quality of life: 6, 12, 24 months (SF-36)

Time to first exacerbation: 24 months (medical notes and hospital records)

Number of participants with $\geq 1$ exacerbation in primary and secondary care: 24 months (medical notes and hospital records)

Visits to pulmonologists and NPs and GPs: 24 months (medical notes and hospital records)

Healthcare provider costs: 24 months (Dutch manual for costing studies and transformed to $2013 \mathrm{Eu}$ ros)

Healthcare insurance costs: 24 months (diagnosis treatment combination of 2013 of the hospital)

Notes $\quad$ Funded by Isala Hospital, no conflicts of interest reported.

\section{Risk of bias}

\begin{tabular}{|c|c|c|}
\hline Bias & Authors' judgement & Support for judgement \\
\hline $\begin{array}{l}\text { Random sequence genera- } \\
\text { tion (selection bias) }\end{array}$ & Low risk & $\begin{array}{l}\text { Randomised with computer minimisation programme to achieve balanced } \\
\text { groups for gender age }(<70 \text { years or }>70 \text { years), and predicted forced expirato- } \\
\text { ry volume in } 1 \text { second }(<40 \% \text { or }>40 \%) \text {. }\end{array}$ \\
\hline $\begin{array}{l}\text { Allocation concealment } \\
\text { (selection bias) }\end{array}$ & Unclear risk & NR. \\
\hline $\begin{array}{l}\text { Blinding of participants } \\
\text { and personnel (perfor- } \\
\text { mance bias) } \\
\text { All outcomes }\end{array}$ & High risk & Participants could not be blinded. \\
\hline $\begin{array}{l}\text { Blinding of outcome as- } \\
\text { sessment (detection bias) } \\
\text { All outcomes }\end{array}$ & High risk & Self-reported questionnaires. \\
\hline
\end{tabular}


Berkhof 2014 (Continued)

Incomplete outcome data Low risk
(attrition bias)

All outcomes

\begin{tabular}{lll}
\hline $\begin{array}{l}\text { Selective reporting (re- } \\
\text { porting bias) }\end{array}$ & Low risk & All outcomes appeared to be reported. \\
\hline Other bias & Low risk & No obvious signs of other bias. \\
\hline
\end{tabular}

Brown 2002

\begin{tabular}{ll}
\hline Methods & Randomised individual, multisite (4 sites) trial, 12 months \\
\hline Participants & UK, 4 hospital clinics (61 participants), breast cancer, women, mean age 65.34 years \\
\hline Interventions & INT $(\mathrm{n}=30)$ : participant to contact BCN by telephone if any problems/ as needed. Given written infor- \\
mation on signs and symptoms of recurrence. Safety net - yearly mammogram. \\
CONT $(\mathrm{n}=31)$ : consultant-led (schedule NR), availability of emergency appointments unclear.
\end{tabular}

Health-related quality of life: 6 and 12 months (EORTC QLQ-C30)
Disease-specific health-related quality of life: 6 and 12 months (EORTC QLQ-BR23)
Psychological morbidity: 6 and 12 months (HADS)
Satisfaction: 6 and 12 months (bespoke tool)
Contact with health professional: 12 months (medical records)

Notes Source of funding and conflicts of interest NR.

Contacted authors for more information, no further data provided.

\begin{tabular}{|c|c|c|}
\hline \multicolumn{3}{|l|}{ Risk of bias } \\
\hline Bias & Authors' judgement & Support for judgement \\
\hline $\begin{array}{l}\text { Random sequence genera- } \\
\text { tion (selection bias) }\end{array}$ & Low risk & Random number list generated by staff. \\
\hline $\begin{array}{l}\text { Allocation concealment } \\
\text { (selection bias) }\end{array}$ & Unclear risk & Details NR. \\
\hline $\begin{array}{l}\text { Blinding of participants } \\
\text { and personnel (perfor- } \\
\text { mance bias) } \\
\text { All outcomes }\end{array}$ & High risk & Participants not blinded; all outcomes self-reported. \\
\hline $\begin{array}{l}\text { Blinding of outcome as- } \\
\text { sessment (detection bias) } \\
\text { All outcomes }\end{array}$ & High risk & Unclear if BCN blinded; all outcomes self-reported. \\
\hline $\begin{array}{l}\text { Incomplete outcome data } \\
\text { (attrition bias) } \\
\text { All outcomes }\end{array}$ & High risk & $\begin{array}{l}20 \% \text { in CONT and } 10 \% \text { in INT lost to 'difficulties in recording' for satisfaction. } \\
\text { Unsure of numbers for EORTC outcome. }\end{array}$ \\
\hline
\end{tabular}


Brown 2002 (Continued)
Selective reporting (re-
Low risk
All outcomes reported for all time points. porting bias)

Other bias

High risk

Some participants not recommended to study due to staff opinion about suitability which was not fully explained; 'presentation bias' as all women who agreed to be part of the study may have felt more positively or may have been more knowledgeable about the PIAS anyway, especially as many women refused participation because they wanted to remain on routine follow-up.

Fredriksson 2016

\begin{tabular}{ll}
\hline Methods & Randomised, individual, multisite (2 sites) trial, 18 months \\
\hline Participants & Sweden; 2 Karolinska University Hospital outpatient clinics (131 participants); RA (who fulfilled the \\
& American College of Rheumatology criteria for RA from 1987); 41 men, 90 females; median age 64 years \\
CONT, 65 years INT
\end{tabular}

Interventions INT $(n=64)$ : participants to contact specialist nurse-led advice line as needed, appointment to be received within 10 working days. Safety net - participant monitored by specialist nurse every 3 months for the period of the study to assess disease activity.

CONT $(n=67)$ : consultant-led clinics (schedule NR), safety net as above, emergency appointments available.

Tender and swollen joint counts: every $3,6,12$ and 18 months (28-joint count according to
handbook)
Disease activity: $3,6,12$ and 18 months (DAS 28)
Number of appointments with rheumatologist: 3, 6, 12 and 18 months (hospital records)
Satisfaction with care: 3, 6, 12 and 18 months (VAS)
Confidence in care: $3,6,12$ and 18 months (VAS)
General health: $3,6,12$ and 18 months (VAS)
Pain: $3,6,12$ and 18 months (VAS)
Erythrocyte sedimentation rate: $3,6,12$ and 18 months (clinical tests)
C-reactive protein 3, 6, 12 and 18 months (clinical tests)
Proportion of participants with DAS $28:<3.2$ at 3, 6, 12 and 18 months (DAS 28)
Functional status: 3, 6, 12 and 18 months (HAQ)
ber 2014-4238) and through the regional agreement on medical training and clinical research (ALF) between the Stockholm County Council and the Karolinska Institute. None declared.

\section{Risk of bias}

\begin{tabular}{lll}
\hline Bias & Authors' judgement & Support for judgement \\
\hline $\begin{array}{l}\text { Random sequence genera- } \\
\text { tion (selection bias) }\end{array}$ & Low risk & $\begin{array}{l}\text { Computer-generated random-number sequence prepared by an independent } \\
\text { party. }\end{array}$ \\
\hline
\end{tabular}


Fredriksson 2016 (Continued)

$\begin{array}{ll}\begin{array}{l}\text { Allocation concealment } \\ \text { (selection bias) }\end{array} \quad \text { Low risk } & \begin{array}{l}\text { Allocation was concealed in envelopes held in a locked location during the } \\ \text { study. }\end{array}\end{array}$
(selection bias)

High risk

Study nurses and participants were aware of the group assignment.

Blinding of participants and personnel (performance bias)

All outcomes

\begin{tabular}{|c|c|c|}
\hline $\begin{array}{l}\text { Blinding of outcome as- } \\
\text { sessment (detection bias) }\end{array}$ & Unclear risk & $\begin{array}{l}\text { Some outcomes would have not been affected by lack of blinding, but others } \\
\text { would. }\end{array}$ \\
\hline
\end{tabular}

All outcomes

\begin{tabular}{|c|c|c|}
\hline $\begin{array}{l}\text { Incomplete outcome data } \\
\text { (attrition bias) } \\
\text { All outcomes }\end{array}$ & Low risk & $\begin{array}{l}\text { Used ITT analysis, report median and IQR and change from baseline for all out- } \\
\text { comes except for number of rheumatology appointments. }\end{array}$ \\
\hline
\end{tabular}

\begin{tabular}{lll}
\hline $\begin{array}{l}\text { Selective reporting (re- } \\
\text { porting bias) }\end{array}$ & Low risk & Appeared to report on all outcomes they intended to. \\
\hline Other bias & Low risk & No obvious signs of other bias. \\
\hline
\end{tabular}

\section{Goodwin 2016}

\begin{tabular}{|c|c|}
\hline Methods & Randomised, individual, single site trial, 12 months \\
\hline Participants & $\begin{array}{l}\text { UK; } 1 \text { hospital clinic ( } 290 \text { participants); RA; } 68 \text { men, } 222 \text { women; mean age } 63.1 \text { years CONT, } 65.4 \text { years } \\
\text { INT }\end{array}$ \\
\hline \multirow[t]{2}{*}{ Interventions } & $\begin{array}{l}\text { INT }(n=138) \text { : participant or GP to contact specialist nurse-led advice line as needed, appointment to be } \\
\text { received within } 10 \text { working days. Safety net - participant contacted by specialist nurse for review if not } \\
\text { been in contact within } 1 \text { year. }\end{array}$ \\
\hline & $\begin{array}{l}\text { CONT }(n=152) \text { : consultant-led clinics (schedule NR), safety net as above, availability of emergency ap- } \\
\text { pointments unclear. }\end{array}$ \\
\hline
\end{tabular}

\begin{tabular}{ll}
\hline Outcomes & Participant satisfaction: 12 months (PSQ-18 plus 5 additional locally relevant questions) \\
& Service use: 12 months (patient records and reports) \\
& Time and expense: 12 months (hospital records and clinical staff discussion) \\
\hline Notes & $\begin{array}{l}\text { Funding - National Institute for Health Research Collaboration for leadership in Applied Health Re- } \\
\text { search and Care South West Peninsula, COI NR }\end{array}$
\end{tabular}

\section{Risk of bias}

\begin{tabular}{lll}
\hline Bias & Authors' judgement & Support for judgement \\
\hline $\begin{array}{l}\text { Random sequence genera- } \\
\text { tion (selection bias) }\end{array}$ & Low risk & Computer-generated. \\
\hline $\begin{array}{l}\text { Allocation concealment } \\
\text { (selection bias) }\end{array}$ & Unclear risk & NR. \\
\hline
\end{tabular}


Goodwin 2016 (Continued)
Blinding of participants
High risk
Blinding not possible. and personnel (performance bias)

All outcomes

\begin{tabular}{lll}
\hline $\begin{array}{l}\text { Blinding of outcome as- } \\
\text { sessment (detection bias) } \\
\text { All outcomes }\end{array}$ & High risk & Self-reported satisfaction; other measures unclear who recorded by. \\
\hline $\begin{array}{l}\text { Incomplete outcome data } \\
\begin{array}{l}\text { (attrition bias) } \\
\text { All outcomes }\end{array}\end{array}$ & High risk & $\begin{array}{l}\text { Some results only available for 58-64\% of the sample and not reported why re- } \\
\text { sults missing; no ITT reported. }\end{array}$ \\
\hline $\begin{array}{l}\text { Selective reporting (re- } \\
\text { porting bias) }\end{array}$ & Low risk & All outcomes reported. \\
\hline \begin{tabular}{l} 
Other bias \\
\hline
\end{tabular} & Low risk & No obvious signs of other bias. \\
\hline
\end{tabular}

Gulliford 1997

\begin{tabular}{ll}
\hline Methods & Randomised, individual, single site trial; median follow-up 16 months \\
\hline Participants & UK, 1 combined breast clinic (196 participants), breast cancer, women only, mean age NR \\
\hline Interventions & $\begin{array}{l}5 \text { wT }(\mathrm{n}=97): \text { participant to contact clinic if any problems/as needed, appointment to be received within } \\
\text { CONT ( } \mathrm{n}=96) \text { : consultant led every } 3 \text { months in first year from diagnosis, every } 4 \text { months in second } \\
\text { year, every } 6 \text { months } 2-5 \text { years and annually for } \geq 5 \text { years. Emergency appointments available. }\end{array}$ \\
\hline Outcomes & $\begin{array}{l}\text { Acceptability of intervention: annually from } 6 \text { months after study entry (MRC quality of life question- } \\
\text { naire + other questions) } \\
\text { Satisfaction of intervention: annually from } 6 \text { months after study entry (MRC quality of life questionnaire } \\
+ \text { other questions) } \\
\text { Interim events: } 16 \text { months (medical records) } \\
\text { Time and expense: } 18 \text { months (MRC quality of life questionnaire + other questions) }\end{array}$ \\
\hline Fotes & Funding - MRC and Cancer Research Campaign, no conflicts of interest.
\end{tabular}

\section{Risk of bias}

\begin{tabular}{lll}
\hline Bias & Authors' judgement & Support for judgement \\
\hline $\begin{array}{l}\text { Random sequence genera- } \\
\text { tion (selection bias) }\end{array}$ & Unclear risk & Details NR. \\
\hline $\begin{array}{l}\text { Allocation concealment } \\
\text { (selection bias) }\end{array}$ & Unclear risk & Details NR. \\
\hline $\begin{array}{l}\text { Blinding of participants } \\
\text { and personnel (perfor- } \\
\text { mance bias) }\end{array}$ & Unclear risk & $\begin{array}{l}\text { Not blinded to allocation and some questionnaires self-reported. Unclear who } \\
\text { retrieved information from hospital records and if they were blinded. }\end{array}$ \\
\hline
\end{tabular}


Gulliford 1997 (Continued)

Blinding of outcome as- High risk Not blinded to allocation and some questionnaires self-reported. Unclear who sessment (detection bias) retrieved information from hospital records and if they were blinded.

All outcomes

Incomplete outcome data Unclear risk Details NR.

(attrition bias)

All outcomes

Selective reporting (re- High risk $\quad$ MRC quality of life NR.
porting bias)

Other bias Low risk No obvious signs of other bias.

Helgesen 2000

\begin{tabular}{ll}
\hline Methods & Randomised, individual, multisite ( 3 sites) trial, 36 months \\
\hline Participants & Sweden, 3 urological departments (400 participants), prostate cancer, men only, mean age 75.8 years \\
\hline Interventions & INT $(n=N R)$ : participant to contact specialist nurse if any problems/as needed. Safety net - nurse tele- \\
phoned after 6 months if patient not been in contact. \\
$\begin{array}{l}\text { CONT }(n=N R) \text { : consultant led every } 2-12 \text { months, emergency appointments available, opportunity for } \\
\text { additional contact with urologist also available. }\end{array}$
\end{tabular}

Outcomes

Psychological morbidity: 6, 12, 18, 24 and 36 months (HADS)

Satisfaction with intervention: 6, 12, 18, 24 and 36 months (bespoke tool)

Contact with healthcare: 36 months (medical records and questionnaire)

Medical interventions and costs: 36 months (medical records and questionnaire)

$\begin{array}{ll}\text { Notes } & \text { Funding - Dagmar-50 project of Swedish Government, Örebro Medical Centre Research Foundation } \\ \text { and the Örebro County Council Research Committee, COI NR. }\end{array}$

\section{Risk of bias}

\begin{tabular}{|c|c|c|}
\hline Bias & Authors' judgement & Support for judgement \\
\hline $\begin{array}{l}\text { Random sequence genera- } \\
\text { tion (selection bias) }\end{array}$ & Unclear risk & Generation NR. \\
\hline $\begin{array}{l}\text { Allocation concealment } \\
\text { (selection bias) }\end{array}$ & Low risk & Closed envelopes. \\
\hline $\begin{array}{l}\text { Blinding of participants } \\
\text { and personnel (perfor- } \\
\text { mance bias) } \\
\text { All outcomes }\end{array}$ & High risk & No-one blinded. \\
\hline $\begin{array}{l}\text { Blinding of outcome as- } \\
\text { sessment (detection bias) } \\
\text { All outcomes }\end{array}$ & High risk & $\begin{array}{l}\text { Unclear who collected hospital data. Participants not blinded and outcomes } \\
\text { are self-reported. }\end{array}$ \\
\hline
\end{tabular}


Helgesen 2000 (Continued)

Incomplete outcome data High risk High mortality; poor reporting of numbers at follow-up per group: 7 partici(attrition bias)

All outcomes

\section{Selective reporting (re-} porting bias)

\section{pants lost to follow-up in CONT group and 1 in INT group. but no reasons giv-}

en.

\begin{tabular}{ll}
\hline Other bias $\quad$ Low risk $\quad$ No obvious signs of other bias. \\
\hline
\end{tabular}

Hewlett 2000

\begin{tabular}{ll}
\hline Methods & Randomised. individual, single site trial, 24, 48 and 72 months \\
\hline Participants & UK; 1 outpatient rheumatology clinic (209 participants); RA; 58 men 124 women; mean age 59 years \\
CONT, 57 years INT
\end{tabular}

Interventions

INT $(n=105)$ : participants contacted nurse-run help line if any problems/as needed. GP provided with information leaflets and could also initiate hospital appointment. Participants could also ask for OT or PT appointment (maximum wait 10 days). Safety net -3 monthly questionnaire to assess clinical status.

CONT $(n=104)$ : consultant-led every 3-4 months, emergency appointments available.

RA status: 24,48 and 72 months (many clinical physiological measures)
Clinical and psychological status: every 3,48 and 72 months (VAS, HAQ, AHI, HADS)
Self-efficacy and changes in medication: SF-36 added at 48,60 and 72 months
Satisfaction with intervention: every 3 months (VAS)
Satisfaction and confidence with intervention: every 12 months at 12, 24, 36, 48 (VAS) (only reported at
48 months)
Resource use: 24 months (medical records, patient diaries and published unit cost data)
Contact with health professionals: 72 months (medical records)

Contacted authors for more information, further data provided for all outcome measures.

\section{Risk of bias}

\begin{tabular}{lll}
\hline Bias & Authors' judgement & Support for judgement \\
\hline $\begin{array}{l}\text { Random sequence genera- } \\
\text { tion (selection bias) }\end{array}$ & Low risk & Computer-generated. \\
\hline $\begin{array}{l}\text { Allocation concealment } \\
\text { (selection bias) }\end{array}$ & Low risk & Concealed in envelopes prepared by third party. \\
\hline $\begin{array}{l}\text { Blinding of participants } \\
\text { and personnel (perfor- } \\
\text { mance bias) }\end{array}$ & High risk & NR. \\
All outcomes & \\
\hline
\end{tabular}


Hewlett 2000 (Continued)

Blinding of outcome as- High risk Unclear who collected data; lead rheumatologist was not blinded. sessment (detection bias)

All outcomes

Incomplete outcome data Low risk Withdrawals and deaths reported and were similar for both groups.
(attrition bias)

(attrition bias)

All outcomes

$\begin{aligned} & \text { Selective reporting (re- High risk } \\ & \text { porting bias) }\end{aligned}$

\begin{tabular}{ll}
\hline Other bias $\quad$ Low risk $\quad$ No obvious signs of other bias. \\
\hline
\end{tabular}

\section{Jeppesen 2018}

\begin{tabular}{ll}
\hline Methods & Randomised, individual, multisite (4 sites) trial, 10 months \\
\hline Participants & $\begin{array}{l}\text { Denmark; } 4 \text { hospital gynaecology departments (212 participants); early-stage endometrial cancer; } \\
\text { women only; mean age } 66.5 \text { years CONT, } 63.4 \text { years INT }\end{array}$
\end{tabular}

Interventions INT ( $n=105)$ : participants were instructed about 'alarm symptoms' that required examination, they could telephone the project nurse to ask for a consultation (or be referred by GP), safety net - none.

CONT $(n=107)$ : consultant-led every 4-6 months for 3 years, emergency appointments unclear.

\begin{tabular}{ll}
\hline Outcomes & Fear of cancer recurrence: 3,6 and 10 months (and 3 years in process, FCRI) \\
Clinical fear of cancer recurrence: 3,6 and 10 months (and 3 years in process, FCRI > 16 on severity sub- \\
scale) \\
Primary care use: 3,6 and 10 months (and 3 years in process, 2 bespoke questions) \\
Telephone contacts: 10 months (chart review) \\
Consultations at hospital: 10 months (chart review) \\
High \% of women declining to participate (95/309), only women who completed the first and fourth \\
questionnaires were included in analysis. \\
Funded by Danish Cancer Society, National Research Centre of Cancer Rehabilitation (University of \\
Southern Denmark), Region of Southern Denmark, and Odense University Hospital. \\
COI - none.
\end{tabular}

\section{Risk of bias}

\begin{tabular}{lll}
\hline Bias & Authors' judgement & Support for judgement \\
\hline $\begin{array}{l}\text { Random sequence genera- } \\
\text { tion (selection bias) }\end{array}$ & Low risk & $\begin{array}{l}\text { Participants randomly assigned following surgery using a computer-based sys- } \\
\text { tem, stratified according to healthcare centre. Randomisation was performed } \\
\text { centrally with a block size of } 10 \text { within each hospital. }\end{array}$ \\
\hline $\begin{array}{l}\text { Allocation concealment } \\
\text { (selection bias) }\end{array}$ & Low risk & Healthcare providers and data analysts blinded to block size during allocation. \\
\hline $\begin{array}{l}\text { Blinding of participants } \\
\begin{array}{l}\text { and personnel (perfor- } \\
\text { mance bias) }\end{array}\end{array}$ & High risk & Patients and healthcare providers could not be blinded to enrolment. \\
\hline
\end{tabular}


Jeppesen 2018 (Continued)

All outcomes

$\begin{array}{lll}\begin{array}{l}\text { Blinding of outcome as- } \\ \text { sessment (detection bias) }\end{array} & \text { High risk } & \begin{array}{l}\text { Data analysts blinded to group assignment until all analyses were complet- } \\ \text { ed using non-identifying terms for the groups but participants had completed } \\ \text { sll outcomes }\end{array}\end{array}$

All outcomes

Similar dropout from each group and no reported significant differences be-

Incomplete outcome data Low risk

(attrition bias)

tween 'responders' and 'non-responders' at baseline.

All outcomes

Selective reporting (re- High risk Not all outcomes reported as per protocol.
porting bias)

porting bias)

Other bias High risk High \% of women declined to participate due to randomisation.

Kennedy 2003

\begin{tabular}{ll}
\hline Methods & Randomised, cluster, multisite (19 sites with randomisation by treatment centre) trial, 12 months \\
\hline Participants & $\begin{array}{l}\text { UK; } 19 \text { hospital outpatient clinics (700 participants); ulcerative colitis or Crohn's disease; } 269 \text { men, } 366 \\
\text { women, mean age 46.34 years CONT, } 44.37 \text { years INT }\end{array}$
\end{tabular}

Interventions INT $(n=297)$ : participants could telephone hospital if any problems/as needed. Participants given initial consultation and a detailed guidebook about their condition and what symptoms to be aware of and prepared a written self-management plan. Safety net - none.

CONT $(n=403)$ : consultant-led appointments as usual (schedule NR), availability of emergency appointments unclear.

\begin{tabular}{|c|c|c|}
\hline \multirow[t]{6}{*}{ Outcomes } & \multicolumn{2}{|c|}{ Disease-related quality of life: 12 months (IBDQ) } \\
\hline & \multicolumn{2}{|c|}{ Quality of life: 12 months (EQ-5D, HADS, SF-36, PEI) } \\
\hline & \multicolumn{2}{|c|}{ Satisfaction: 12 months (bespoke questionnaire) } \\
\hline & \multicolumn{2}{|c|}{ Interim events: 12 months (medical records and patient diaries) } \\
\hline & \multicolumn{2}{|c|}{ Symptoms: 12 months (patient diaries) } \\
\hline & \multicolumn{2}{|c|}{ Economic costs: 12 months (patient diaries and medical records, EQ-5D) } \\
\hline \multirow[t]{4}{*}{ Notes } & \multicolumn{2}{|c|}{ Economic evaluation - health service resource use and cost effectiveness using EQ-5D. } \\
\hline & \multicolumn{2}{|c|}{ Funded by NHS Research and Development Health Technology Assessment Programme. } \\
\hline & \multicolumn{2}{|l|}{ COI NR. } \\
\hline & \multicolumn{2}{|c|}{ Contacted authors for more information, further data provided for IBDQ and depression. } \\
\hline \multicolumn{3}{|l|}{ Risk of bias } \\
\hline Bias & Authors' judgement & Support for judgement \\
\hline $\begin{array}{l}\text { Random sequence genera- } \\
\text { tion (selection bias) }\end{array}$ & Low risk & $\begin{array}{l}\text { The } 19 \text { remaining hospital sites were randomly ordered from } 1 \text { to } 19 \text { (by a sta- } \\
\text { tistician not associated with the study using a prepared sequence of random } \\
\text { numbers), and these numbers were randomly drawn out of a hat allocating } \\
\text { each hospital either to the CONT group ( } 10 \text { sites) or INT group ( } 9 \text { sites). }\end{array}$ \\
\hline
\end{tabular}


Kennedy 2003 (Continued)

Allocation concealment Low risk The 19 remaining hospital sites were randomly ordered from 1 to 19 (by a sta(selection bias) tistician not associated with the study using a prepared sequence of random numbers), and these numbers were randomly drawn out of a hat allocating each hospital either to the CONT group (10 sites) or INT group (9 sites).

Blinding of participants High risk Participants not blinded.
and personnel (perfor-
mance bias)
All outcomes

\begin{tabular}{|c|c|c|}
\hline $\begin{array}{l}\text { Blinding of outcome as- } \\
\text { sessment (detection bias) } \\
\text { All outcomes }\end{array}$ & High risk & Unclear if assessors blinded and outcomes mainly self-reported. \\
\hline $\begin{array}{l}\text { Incomplete outcome data } \\
\text { (attrition bias) } \\
\text { All outcomes }\end{array}$ & Low risk & $\begin{array}{l}\text { Reasons for loss to follow-up were listed and loss was similar between groups. } \\
\text { ITT analysis conducted. }\end{array}$ \\
\hline $\begin{array}{l}\text { Selective reporting (re- } \\
\text { porting bias) }\end{array}$ & Low risk & All outcomes detailed in the methods section were reported. \\
\hline Other bias & Low risk & No obvious signs of other bias. \\
\hline
\end{tabular}

\section{Khoury 2018}

\begin{tabular}{ll}
\hline Methods & Randomised, individual, single-site trial, 52 weeks \\
\hline Participants & $\begin{array}{l}\text { Denmark; } 1 \text { hospital (150 participants); psoriasis; } 95 \text { men, } 55 \text { women; mean age } 47.4 \text { years CONT, } 51.5 \\
\text { years INT }\end{array}$ \\
\hline
\end{tabular}

Interventions $\quad$ INT $(n=73)$ : participants were able to request a consultation when needed via a telephone helpline managed by specialist nurses who could also provide advice and assistance. Laboratory tests every 12 weeks. Safety net -1 scheduled annual appointment with dermatologist.

CONT ( $n=77)$ : consultant-led every $12-16$ weeks plus laboratory tests as in INT group, emergency appointments available.

Health-related quality of life: 52 weeks (DLQI)
Psychological well-being: 52 weeks (HADS)
Satisfaction with the system: 52 weeks (3 questions on Likert scale)
Appointment use due to psoriasis: 52 weeks (medical records)
Treatment safety: $12-16$ weeks for 52 weeks (laboratory tests)
Clinical monitoring: 52 weeks (PASI, physiological clinical measurements)

\section{Notes}

All participants interested had a mandatory information meeting to hear about the study. Patients had to collect medication and have laboratory tests every 12 weeks (checked monthly by lead researcher). The lead researcher provided face-to-face information to patients on their safety and recognising difficulties/flare-ups and access to help through the helpline.

Patient adherence checked monthly. Patients who failed to attend their laboratory test or pick up medication were telephoned and encouraged along. Patients who failed to adhere $>3$ times were excluded from the study. 
Khoury 2018 (Continued)

Funded by Capital region of Denmark, Johannes Foghs Fond and The Danish National Psoriasis Association. COI: C.Z. has served as a scientific consultant for AbbVie, Almirall, Pfizer, Janssen-Cilag, Merck \& Co., Inc., Eli Lilly, Takeda and Novartis, and as a clinical study investigator for AbbVie, LEO Pharma, Amgen, Eli Lilly, Merck \& Co., Inc., Takeda and Novartis. L.S. has received research grants from Pfizer, Janssen-Cilag and LEO Pharma, and served as a scientific consultant for AbbVie, Almirall, Pfizer, Janssen-Cilag, LEO Pharma, Eli Lilly, Celgene and Novartis, and as a clinical study investigator for AbbVie, Amgen, Eli Lilly, LEO Pharma, Takeda and Novartis.

Contacted authors for more information, further data provided for DLQI, HADS and satisfaction with the system.

\section{Risk of bias}

\begin{tabular}{|c|c|c|}
\hline Bias & Authors' judgement & Support for judgement \\
\hline $\begin{array}{l}\text { Random sequence genera- } \\
\text { tion (selection bias) }\end{array}$ & Low risk & $\begin{array}{l}\text { Randomised at an individual level by a computer-generated algorithm, strati- } \\
\text { fied according to sex and medical treatment. }\end{array}$ \\
\hline $\begin{array}{l}\text { Allocation concealment } \\
\text { (selection bias) }\end{array}$ & Unclear risk & Allocation did not appear to be concealed. \\
\hline $\begin{array}{l}\text { Blinding of participants } \\
\text { and personnel (perfor- } \\
\text { mance bias) } \\
\text { All outcomes }\end{array}$ & High risk & $\begin{array}{l}\text { Blinding not feasible, which may have influenced self-reported outcomes such } \\
\text { as DLQI and HADS. }\end{array}$ \\
\hline $\begin{array}{l}\text { Blinding of outcome as- } \\
\text { sessment (detection bias) } \\
\text { All outcomes }\end{array}$ & High risk & No attempt to conceal allocation from data analysts. \\
\hline $\begin{array}{l}\text { Incomplete outcome data } \\
\text { (attrition bias) } \\
\text { All outcomes }\end{array}$ & Low risk & Very low levels of withdrawals or missing data but no ITT attempted. \\
\hline $\begin{array}{l}\text { Selective reporting (re- } \\
\text { porting bias) }\end{array}$ & High risk & $\begin{array}{l}\text { Protocol suggested outcomes were to be reported at } 2 \text { years; this article was } \\
\text { at } 1 \text { year and did not cover all the outcomes planned in the protocol. Patients } \\
\text { who failed to adhere more than } 3 \text { times were excluded from the analysis. }\end{array}$ \\
\hline Other bias & Low risk & No obvious signs of other bias. \\
\hline
\end{tabular}

Kirshbaum 2017

\begin{tabular}{ll}
\hline Methods & Randomised, individual, single-site trial, 24 months \\
\hline Participants & UK; 1 hospital (112 participants); breast cancer; women only; mean age 60.5 years CONT, 60.7 years INT \\
\hline Interventions & $\begin{array}{l}\text { INT }(\mathrm{n}=56) \text { : participants to contact nurse-run helpline as needed. Participants also received } 4 \text { psychoe- } \\
\text { ducational sessions and a resource pack. Safety net - none. } \\
\text { CONT ( } \mathrm{n}=56) \text { : schedule NR. Participants also received same psychoeducational sessions but without } \\
\text { resource pack, availability of emergency appointments unclear. }\end{array}$ \\
\hline Outcomes & Anxiety and depression: 6, 12, 18 and 24 months (HADS) \\
& Quality of life: 6, 12, 18 and 24 months (EORTC QLQ-C30 and EORTC QLQ-BR23) \\
\hline
\end{tabular}


Kirshbaum 2017 (Continued)

Notes

All participants received 4 psychoeducational sessions (half-days over 4 weeks called 'Moving Forward') addressing the management and impact of breast cancer, breast reconstruction, lymphoedema, exercise, breast awareness after surgery, healthy eating and management of menopausal symptoms.

Funded NR.

COI - none.

\section{Risk of bias}

\begin{tabular}{|c|c|c|}
\hline Bias & Authors' judgement & Support for judgement \\
\hline $\begin{array}{l}\text { Random sequence genera- } \\
\text { tion (selection bias) }\end{array}$ & Unclear risk & Not described. \\
\hline $\begin{array}{l}\text { Allocation concealment } \\
\text { (selection bias) }\end{array}$ & Unclear risk & Not described. \\
\hline $\begin{array}{l}\text { Blinding of participants } \\
\text { and personnel (perfor- } \\
\text { mance bias) } \\
\text { All outcomes }\end{array}$ & High risk & $\begin{array}{l}\text { Blinding could not be achieved due to the nature of the intervention and being } \\
\text { conducted on } 1 \text { hospital site. }\end{array}$ \\
\hline $\begin{array}{l}\text { Blinding of outcome as- } \\
\text { sessment (detection bias) } \\
\text { All outcomes }\end{array}$ & High risk & Self-reported quality of life questionnaires. \\
\hline $\begin{array}{l}\text { Incomplete outcome data } \\
\text { (attrition bias) } \\
\text { All outcomes }\end{array}$ & Unclear risk & $\begin{array}{l}\text { Appropriate dealing with missing values was evident but no information on } \\
\text { how much missing data from each group, and quite likely missing data could } \\
\text { have been directly linked to the outcome being measured. }\end{array}$ \\
\hline $\begin{array}{l}\text { Selective reporting (re- } \\
\text { porting bias) }\end{array}$ & Low risk & All recorded data seemed to be reported in tables. \\
\hline Other bias & Unclear risk & Both groups received educational material. \\
\hline
\end{tabular}

Koinberg 2004

\begin{tabular}{|c|c|}
\hline Methods & Randomised, individual, multisite ( 3 sites) trial, 60 months \\
\hline Participants & $\begin{array}{l}\text { Sweden; } 3 \text { hospitals ( } 264 \text { participants); breast cancer; women only; mean age } 58.8 \text { years CONT, } 60 \text { years } \\
\text { INT }\end{array}$ \\
\hline \multirow[t]{2}{*}{ Interventions } & $\begin{array}{l}\text { INT }(n=133) \text { : participant to telephone nurse if any problems/as needed. Nurse provided advice or } \\
\text { could seek assistance from a specialist and make further appointments. Safety net - yearly mammog- } \\
\text { raphy. }\end{array}$ \\
\hline & $\begin{array}{l}\text { CONT }(n=131) \text { : consultant-led } 4 \text { times per year in first } 2 \text { years after surgery then twice per year up to } 5 \\
\text { years then once per year thereafter, yearly mammography. Availability of emergency appointments un- } \\
\text { clear. }\end{array}$ \\
\hline
\end{tabular}

Outcomes Anxiety and depression: every 6 months to 3 years +5 years (HADS)

Satisfaction and accessibility: every 6 months to 3 years +5 years (SaaC)

Medical examinations, visits and telephone contacts: 60 months (medical records) 
Contact with other physicians breast cancer-related: 60 months (medical records)

Number of breast cancer-related diagnostic procedures: 60 months (medical records)

Notes

Participants attend an initial consultation with the nurse approximately 3 months after surgery, where participant received information on recognising recurrence in breast, skin, axilla and scar tissue. Participant returned to usual care after 3 years. Funded by the Cancer and Traffic Federation Sweden and the County Council of Halland Sweden. COI NR.

Contacted authors for more information, further data provided for contacts with other physicians.

\section{Risk of bias}

\begin{tabular}{lll}
\hline Bias & Authors' judgement & Support for judgement \\
\hline $\begin{array}{l}\text { Random sequence genera- } \\
\text { tion (selection bias) }\end{array}$ & Low risk & Computer-generated randomisation. \\
\hline $\begin{array}{l}\text { Allocation concealment } \\
\text { (selection bias) }\end{array}$ & Low risk & $\begin{array}{l}\text { Randomisation was achieved by telephone contact with an external secretari- } \\
\text { at. }\end{array}$ \\
\hline $\begin{array}{l}\text { Blinding of participants } \\
\text { and personnel (perfor- } \\
\text { mance bias) }\end{array}$ & High risk & Not possible for participants or personnel. \\
All outcomes & & \\
\hline
\end{tabular}

\begin{tabular}{|c|c|c|}
\hline $\begin{array}{l}\text { Blinding of outcome as- } \\
\text { sessment (detection bias) }\end{array}$ & High risk & $\begin{array}{l}\text { Both measures self-report, except case notes; otherwise unclear if assessors } \\
\text { blinded. }\end{array}$ \\
\hline
\end{tabular}

All outcomes

\begin{tabular}{|c|c|c|}
\hline $\begin{array}{l}\text { Incomplete outcome data } \\
\text { (attrition bias) } \\
\text { All outcomes }\end{array}$ & Unclear risk & $\begin{array}{l}\text { Group that was not analysed due to wrong intervention; otherwise all analyses } \\
\text { were ITT and all-cause mortality was the same in both groups. }\end{array}$ \\
\hline
\end{tabular}

Selective reporting (re- High risk $\quad$ No data at 30 and 36 months.
porting bias)

\begin{tabular}{lll}
\hline Other bias & High risk & Complications with intervention delivery. \\
\hline
\end{tabular}

\section{Lahdensuo 1996}

\begin{tabular}{|c|c|}
\hline Methods & Randomised, individual, multisite ( 3 sites) trial, 12 months \\
\hline Participants & $\begin{array}{l}\text { Finland; } 3 \text { outpatient clinics ( } 122 \text { participants); asthma; men 43, women 72; mean age } 42.8 \text { years CONT, } \\
40.6 \text { years INT }\end{array}$ \\
\hline \multirow[t]{2}{*}{ Interventions } & $\begin{array}{l}\text { INT }(n=60) \text { : participant contacted nurse or doctor if peak expiratory flow fell below } 85 \% \text { and did not } \\
\text { reach optimal peak flow within } 2 \text { weeks or if peak expiratory flow fell below } 70 \% \text { optimal value. Partic- } \\
\text { ipants given personal education by trained nurses. Safety net - participants visited outpatient depart- } \\
\text { ment every } 4 \text { months. }\end{array}$ \\
\hline & $\begin{array}{l}\text { CONT }(n=62) \text { : consultant-led appointment every } 4 \text { months. Participants were advised how to use their } \\
\text { inhalers correctly and given general information on their disease during the routine visits to the outpa- } \\
\text { tient department. Availability of emergency appointments unclear. Participants visited outpatient de- } \\
\text { partment every } 4 \text { months. }\end{array}$ \\
\hline
\end{tabular}


Lahdensuo 1996 (Continued)

Outcomes
Days off work, admissions to hospital, unscheduled visits to care and drug use: 12 months (medical records, patient diaries, or both)

Lung function: 4, 8 and 12 months (spirometry and patient diaries)

Quality of life: 4, 8 and 12 months (selected components of the SGRQ)

Adverse events: 4, 8 and 12 months (medical records)

Notes

Funded by Suomen Astra Oy.

COINR.

\begin{tabular}{|c|c|c|}
\hline \multicolumn{3}{|l|}{ Risk of bias } \\
\hline Bias & Authors' judgement & Support for judgement \\
\hline $\begin{array}{l}\text { Random sequence genera- } \\
\text { tion (selection bias) }\end{array}$ & Low risk & $\begin{array}{l}\text { Quote: "The block randomisation method was used ... randomisation lists } \\
\text { were prepared separately for each centre by computer." }\end{array}$ \\
\hline $\begin{array}{l}\text { Allocation concealment } \\
\text { (selection bias) }\end{array}$ & Low risk & $\begin{array}{l}\text { Quote: "The method of sealed numbered envelopes were used in patient allo- } \\
\text { cation." }\end{array}$ \\
\hline $\begin{array}{l}\text { Blinding of participants } \\
\text { and personnel (perfor- } \\
\text { mance bias) } \\
\text { All outcomes }\end{array}$ & High risk & Not possible. \\
\hline $\begin{array}{l}\text { Blinding of outcome as- } \\
\text { sessment (detection bias) } \\
\text { All outcomes }\end{array}$ & Unclear risk & $\begin{array}{l}\text { While this trial was described in the methods as "single blind", we found no } \\
\text { reference in the paper that described or explained how the assessment was } \\
\text { blinded. }\end{array}$ \\
\hline $\begin{array}{l}\text { Incomplete outcome data } \\
\text { (attrition bias) } \\
\text { All outcomes }\end{array}$ & High risk & $\begin{array}{l}\text { Number of withdrawals similar between groups, but no ITT analysis conduct- } \\
\text { ed. }\end{array}$ \\
\hline $\begin{array}{l}\text { Selective reporting (re- } \\
\text { porting bias) }\end{array}$ & Low risk & Results for all outcomes mentioned in the methods were reported. \\
\hline Other bias & Low risk & No obvious signs of other bias. \\
\hline
\end{tabular}

\section{Primdahl 2012}

\begin{tabular}{ll}
\hline Methods & Randomised, individual, multisite ( 2 sites, 3 arms) trial, 12 and 24 months \\
\hline Participants & $\begin{array}{l}\text { Denmark; } 2 \text { hospital outpatient rheumatology clinics (287 participants in } 3 \text { arms, CONT and INT of in- } \\
\text { terest }=193) ; \text { RA; } 58 \text { men, } 135 \text { women; mean age } 61.1 \text { years }\end{array}$ \\
\hline Interventions & $\begin{array}{l}\text { INT }(n=96) \text { : participant (or GP) to contact nurse by telephone for advice or appointment as necessary. } \\
\text { GP managed medication according to algorithm from rheumatology department. Safety net - annual } \\
\text { hospital review. } \\
\text { CONT }(n=97): \text { consultant-led every } 3 \text { months to } 1 \text { year depending on clinician judgement. Emergency } \\
\text { appointments available. }\end{array}$
\end{tabular}


Primdahl 2012 (Continued)

Outcomes

Disease activity: baseline, 12 and 24 months (DAS 28 CRP)

Disability: baseline, 12 and 24 months (HAQ Danish version)

Pain and fatigue: baseline and 12 months (VAS)

Self-efficacy: baseline, 3, 12 and 24 months (RASE and ASES)

Satisfaction/confidence in care: baseline, 12 and 24 months (VAS)

Disease activity: every 3 months (Rheumatoid Arthritis Disease Activity Index)

Quality of life: baseline, 12 and 24 (EQ-5D-5L)

Resource use and costs: baseline, 12 and 24 months (questionnaires, hourly rates and medical records)

Notes

All participants received $20 \times 3$-hour sessions from a rheumatologist, an OT, PT and a nurse on how to manage disease-related problems in everyday life and to know when to seek help (details on page 122). Participants were allocated after receiving this education. Participants in INT group were contacted by nurses if their disease activity, disability or adverse events scores rose by more than $20 \%$.

Funded by University of Southern Denmark, Sygehus Sonderjylland, region of Southern Denmark, Hans Christensen's Memorial Foundation, Gigtforeningen and King Christian X's Hospital for Rheumatic Diseases.

COINR.

Contacted authors for more information, further data provided for all outcome measures.

\section{Risk of bias}

\begin{tabular}{|c|c|c|}
\hline Bias & Authors' judgement & Support for judgement \\
\hline $\begin{array}{l}\text { Random sequence genera- } \\
\text { tion (selection bias) }\end{array}$ & Low risk & Computer-generated randomisation. \\
\hline $\begin{array}{l}\text { Allocation concealment } \\
\text { (selection bias) }\end{array}$ & Low risk & $\begin{array}{l}\text { Distributed in closed envelopes by secretary who knew the allocation (we be- } \\
\text { lieve). Therefore, it is possible they let others know, although we consider it } \\
\text { would still be a low risk. }\end{array}$ \\
\hline $\begin{array}{l}\text { Blinding of participants } \\
\text { and personnel (perfor- } \\
\text { mance bias) } \\
\text { All outcomes }\end{array}$ & High risk & Could not be blinded and measures were self-reported. \\
\hline $\begin{array}{l}\text { Blinding of outcome as- } \\
\text { sessment (detection bias) } \\
\text { All outcomes }\end{array}$ & High risk & All outcomes were self-reported; blinding of study personnel not described. \\
\hline $\begin{array}{l}\text { Incomplete outcome data } \\
\text { (attrition bias) } \\
\text { All outcomes }\end{array}$ & Low risk & 16 participants left in first year of study, unclear from which group. \\
\hline $\begin{array}{l}\text { Selective reporting (re- } \\
\text { porting bias) }\end{array}$ & Low risk & All outcomes reported at all time points. \\
\hline Other bias & Low risk & No obvious signs of other bias. \\
\hline
\end{tabular}


Robinson 2001

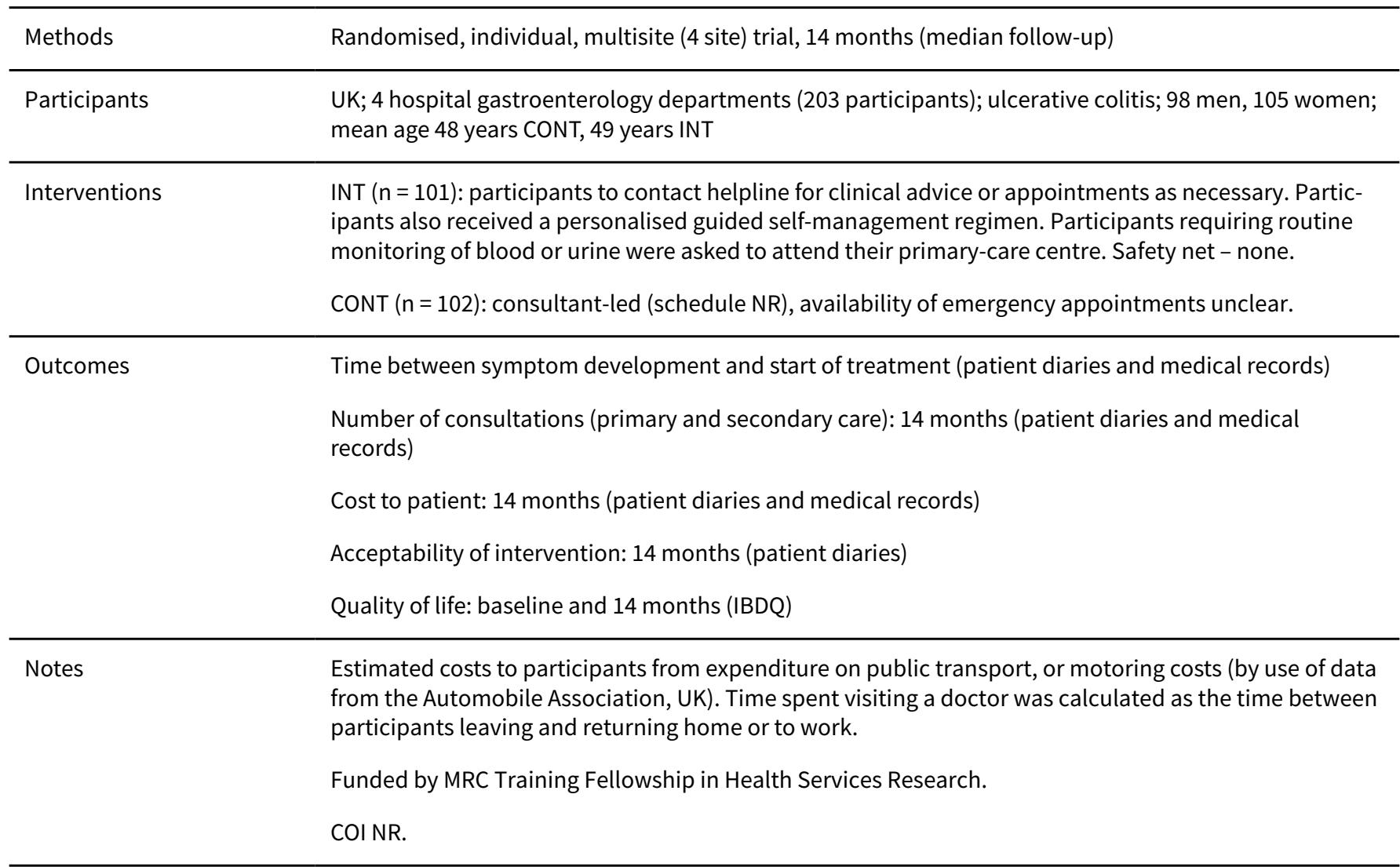

\section{Risk of bias}

\begin{tabular}{lll}
\hline Bias & Authors' judgement & Support for judgement \\
\hline $\begin{array}{l}\text { Random sequence genera- } \\
\text { tion (selection bias) }\end{array}$ & Low risk & $\begin{array}{l}\text { The first 20 participants in each centre were randomly allocated to groups by } \\
\text { random number tables. }\end{array}$ \\
\hline $\begin{array}{l}\text { Allocation concealment } \\
\text { (selection bias) }\end{array}$ & Low risk & $\begin{array}{l}\text { Subsequent participants were allocated by the process of minimisation which } \\
\text { was done by an assistant not involved in the rest of the trial. }\end{array}$ \\
\hline $\begin{array}{l}\text { Blinding of participants } \\
\text { and personnel (perfor- } \\
\text { mance bias) } \\
\text { All outcomes }\end{array}$ & High risk & Blinding of study personnel not described. \\
\hline
\end{tabular}

Blinding of outcome as- Unclear risk Blinding of study personnel not described.

sessment (detection bias)

All outcomes

\begin{tabular}{|c|c|c|}
\hline $\begin{array}{l}\text { Incomplete outcome data } \\
\text { (attrition bias) }\end{array}$ & Low risk & $\begin{array}{l}\text { Reasons for loss to follow-up were given for both groups, which were similar } \\
\text { across groups (more lost from CONT group than INT group). }\end{array}$ \\
\hline
\end{tabular}

All outcomes

\begin{tabular}{lll}
\hline $\begin{array}{l}\text { Selective reporting (re- } \\
\text { porting bias) }\end{array}$ & High risk & $\begin{array}{l}\text { All outcomes mentioned in methods section were reported (although full de- } \\
\text { tails were not given for non-significant results). }\end{array}$ \\
\hline Other bias & Low risk & No obvious signs of other bias. \\
\hline
\end{tabular}


Sheppard 2009

\begin{tabular}{ll}
\hline Methods & Randomised, individual, single-site trial, 18 months \\
\hline Participants & UK, 1 specialist breast unit (237 participants), breast cancer, women only, mean age 57 years \\
\hline Interventions & INT ( $\mathrm{n}=107)$ : participants to contact nurse specialist by telephone as necessary, safety net - yearly \\
& $\begin{array}{l}\text { CONT ( } \mathrm{n}=107) \text { : nurse- or consultant-led every } 6 \text { months, received yearly mammograms, availability of } \\
\text { emergency appointments unclear. }\end{array}$ \\
\hline Outcomes & Psychological morbidity: baseline, 9 and 18 months (GHQ 12) \\
& Quality of life: baseline, 9 and 18 months (FACT-B) \\
& Recurrences: 18 months (medical records) \\
Fear of recurrence: baseline, 9 and 18 months (3 item fear questionnaire) \\
Isolation: 9 and 18 months (1 question) \\
Funded by Wessex Cancer Trust. \\
No COI. \\
Contacted authors for more information, further data provided for all outcome measures.
\end{tabular}

\section{Risk of bias}

\begin{tabular}{|c|c|c|}
\hline Bias & Authors' judgement & Support for judgement \\
\hline $\begin{array}{l}\text { Random sequence genera- } \\
\text { tion (selection bias) }\end{array}$ & Low risk & Computer-generated random assignment. \\
\hline $\begin{array}{l}\text { Allocation concealment } \\
\text { (selection bias) }\end{array}$ & Low risk & Allocations produced externally and delivered in sealed envelopes. \\
\hline $\begin{array}{l}\text { Blinding of participants } \\
\text { and personnel (perfor- } \\
\text { mance bias) } \\
\text { All outcomes }\end{array}$ & High risk & $\begin{array}{l}\text { Participants were informed of allocation following randomisation externally } \\
\text { and in sealed envelopes. }\end{array}$ \\
\hline $\begin{array}{l}\text { Blinding of outcome as- } \\
\text { sessment (detection bias) } \\
\text { All outcomes }\end{array}$ & High risk & Self-reported measures and not blinded from intervention allocation. \\
\hline $\begin{array}{l}\text { Incomplete outcome data } \\
\text { (attrition bias) } \\
\text { All outcomes }\end{array}$ & High risk & $\begin{array}{l}\text { We do not know which group the participants lost to follow-up were in and } \\
\text { they were excluded from analysis. }\end{array}$ \\
\hline $\begin{array}{l}\text { Selective reporting (re- } \\
\text { porting bias) }\end{array}$ & Low risk & All outcomes reported at all time points. \\
\hline Other bias & High risk & $\begin{array}{l}23 \% \text { of those invited declined to participate thus affecting the sample preran- } \\
\text { domisation. }\end{array}$ \\
\hline
\end{tabular}


Williams 2000

\begin{tabular}{|c|c|}
\hline Methods & Randomised, individual, multisite ( 2 sites) trial, 24 months \\
\hline Participants & UK, 2 district general hospitals (180 participants), inflammatory bowel disease, sex NR, mean age NR \\
\hline \multirow[t]{2}{*}{ Interventions } & $\begin{array}{l}\text { INT }(n=88) \text { : participants to contact GP or hospital for advice or appointments as necessary, initial care } \\
\text { move back to GP so GP could also contact hospital on behalf of patient. Safety net - review appoint- } \\
\text { ment at } 24 \text { months and regular colonoscopy for those who needed it. }\end{array}$ \\
\hline & CONT $(n=92)$ : consultant-led (schedule NR), emergency appointments available. \\
\hline \multirow[t]{3}{*}{ Outcomes } & Quality of life: 6, 12, 18 and 24 months (SF-36 and IBDQ) \\
\hline & Resource use: 24 months (patient questionnaires and medical records) \\
\hline & Patient and GP satisfaction and preferences: 24 months (unspecified questionnaire) \\
\hline \multirow[t]{2}{*}{ Notes } & $\begin{array}{l}\text { Funded by NHS Research and Development Primary/Secondary Care interface Programme with sup- } \\
\text { plementary support from the West Wales and Swansea Group of the National Association for Colitis and } \\
\text { Crohn's Disease. }\end{array}$ \\
\hline & No COI. \\
\hline
\end{tabular}

\section{Risk of bias}

\begin{tabular}{|c|c|c|}
\hline Bias & Authors' judgement & Support for judgement \\
\hline $\begin{array}{l}\text { Random sequence genera- } \\
\text { tion (selection bias) }\end{array}$ & Low risk & $\begin{array}{l}\text { Participants stratified by centre and between } 4 \text { diagnostic groups. Allocation } \\
\text { was computer-generated. }\end{array}$ \\
\hline $\begin{array}{l}\text { Allocation concealment } \\
\text { (selection bias) }\end{array}$ & Low risk & $\begin{array}{l}\text { Allocation lists held securely by independent researcher in each centre. When } \\
\text { eligibility of participant confirmed, researcher contacted for random assign- } \\
\text { ment. }\end{array}$ \\
\hline $\begin{array}{l}\text { Blinding of participants } \\
\text { and personnel (perfor- } \\
\text { mance bias) } \\
\text { All outcomes }\end{array}$ & High risk & No blinding described. \\
\hline $\begin{array}{l}\text { Blinding of outcome as- } \\
\text { sessment (detection bias) } \\
\text { All outcomes }\end{array}$ & High risk & $\begin{array}{l}\text { Self-reported questionnaires, but unclear if staff who collected information } \\
\text { from medical records were blinded. }\end{array}$ \\
\hline $\begin{array}{l}\text { Incomplete outcome data } \\
\text { (attrition bias) } \\
\text { All outcomes }\end{array}$ & Low risk & $\begin{array}{l}\text { Reminders sent to non-respondents for questionnaires, unclear if any were un- } \\
\text { returned. } 5 \text { participants withdrew. Number of withdrawals and uncompleted } \\
\text { questionnaires described for each group. Analysis by intention to follow-up. }\end{array}$ \\
\hline $\begin{array}{l}\text { Selective reporting (re- } \\
\text { porting bias) }\end{array}$ & Low risk & All outcomes reported. \\
\hline Other bias & Unclear risk & Impact of GP involvement in intervention unclear. \\
\hline
\end{tabular}

AHI: Arthritis Helplessness Index; ASES: Arthritis Self-Efficacy Scale; BCN: breast care nurse; CCQ: Clinical COPD Questionnaire; COI: conflict of interest; CONT: control group; COPD: chronic obstructive pulmonary disease; DAS 28: Disease Activity Scale; DLQI: Dermatology Life Quality Index; EORTC QLQ: European Organization for Research and Treatment of Cancer Quality of Life Questionnaire; EORTC QLQ-C30: 30item EORTC QLQ; EORTC QLQ-BR23: 23-item breast-specific EORTC QLQ; EQ-5D: Euro Qol 5D; EQ-5D-5L: 5-level Euro Qol; EULAR: European League Against Rheumatism; FACT-B: Functional Assessment for Cancer Therapy - Breast; FCRI: Fear of Cancer Recurrence Inventory; GHQ: General Health Questionnaire; GP: general practitioner; HADS: Hospital Anxiety and Depression Scale; HAQ: Health Assessment Questionnaire; IBDQ: Inflammatory Bowel Disease Questionnaire; INT: intervention group; IQR: interquartile range; ITT: intention-to- 
treat; MRC: Medical Research Council; n: number of participants; NP: nurse practitioner; NR: not reported; OT: occupational therapy/ ist; PASI: Psoriasis Area and Severity Index; PEI: Patient Enablement Instrument; PIAS: patient-initiated appointment system; PSQ-18: Patient Satisfaction Questionnaire; PT: physiotherapy/ist; RA: rheumatoid arthritis; RASE: Rheumatoid Arthritis Self-Efficacy Scale; SaaC: Satisfaction and accessibility Scale; SF-36: 36-item Short Form; SGRQ: St George's Respiratory Questionnaire; VAS: visual analogue scale.

\section{Characteristics of excluded studies [ordered by study ID]}

\begin{tabular}{|c|c|}
\hline Study & Reason for exclusion \\
\hline Adams 2009 & Wrong study design. \\
\hline Arnaud 1997 & Wrong study design. \\
\hline Booth 2001 & Wrong study design. \\
\hline Bourbeau 2003 & Wrong intervention. \\
\hline Coenen 2017 & Wrong study design. \\
\hline Dent 2011 & Wrong study design. \\
\hline Emery 2014a & Wrong intervention. \\
\hline Emery 2014b & Wrong intervention. \\
\hline Emery 2017 & Wrong intervention. \\
\hline Fournier 2015 & Wrong population/setting. \\
\hline Hesselink 2011 & Wrong intervention. \\
\hline Hewlett 2005 & Wrong study design. \\
\hline Lawlor 2009 & Wrong study design. \\
\hline McBain 2014a & Wrong intervention. \\
\hline McBain 2014b & Wrong intervention. \\
\hline McBain 2015 & Wrong intervention. \\
\hline Ndosi 2011 & Wrong intervention. \\
\hline Paudyal 2012 & Wrong study design. \\
\hline Pope 2005 & Wrong study design. \\
\hline Pope 2014 & Wrong study design. \\
\hline Rogers 2004 & Wrong study design. \\
\hline Sands 2009 & Wrong study design. \\
\hline Schougaard 2019 & Wrong intervention. \\
\hline
\end{tabular}




\section{Characteristics of ongoing studies [author-defined order]}

\section{NCT02577224}

Trial name or title

An RCT of a patient-initiated treatment service for BEB and HFS

\begin{tabular}{ll}
\hline Methods & Randomised controlled trial \\
\hline Participants & Adults with a diagnosis of hemifacial spasm or blepharospasm, attending a hospital-based botu- \\
& linum toxin clinic at Moorfields Eye Hospital NHS Foundation Trust, who are stable on botulinum \\
& toxin treatment, defined as receiving toxin treatment at stable doses over 2 previous cycles and \\
free from adverse effects.
\end{tabular}

Interventions

Participants will initiate their own treatment during the 9 months of the trial. They will receive information about when and how to initiate an appointment. Contact details for the service will be provided along with information on how quickly an appointment will be made, with whom and the procedure in the case of an emergency. All participants requesting an appointment will be booked into the next available slot within the twice weekly ring-fenced nurse-led clinics. Any subsequent scheduled appointments will be cancelled and all future treatment will be initiated by the patient.

Outcomes

Disease severity, disability, patient satisfaction, adverse effects, confidence in system of care, quality of life, mood, Illness perceptions, treatment beliefs, acceptability and cost effectiveness.

\begin{tabular}{ll}
\hline Starting date & August 2015 \\
\hline Contact information & Daniel Ezra, MD FRCOph, Moorfields Eye Hospital NHS Foundation Trust
\end{tabular}

Abbreviations

Notes

BEB: benign essential blepharospasm; HFS: hemifacial spasm; RCT: randomised controlled trial.

\section{DATA AND ANALYSES}

Comparison 1. Patient-initiated appointment systems versus consultant-led appointment systems

\begin{tabular}{|c|c|c|c|c|}
\hline Outcome or subgroup title & $\begin{array}{l}\text { No. of } \\
\text { studies }\end{array}$ & $\begin{array}{l}\text { No. of } \\
\text { partici- } \\
\text { pants }\end{array}$ & Statistical method & Effect size \\
\hline $\begin{array}{l}1 \text { Patient outcomes: anxiety } \\
\text { (HADS lower score = better 0- } \\
\text { 21) (12-24 months) }\end{array}$ & 5 & & Odds Ratio (Random, 95\% Cl) & $0.87[0.68,1.12]$ \\
\hline 1.1 Cancer & 3 & & Odds Ratio (Random, 95\% Cl) & $0.94[0.55,1.59]$ \\
\hline 1.2 Psoriasis & 1 & & Odds Ratio (Random, 95\% Cl) & $0.89[0.64,1.23]$ \\
\hline 1.3 Rheumatoid arthritis & 1 & & Odds Ratio (Random, 95\% Cl) & $0.70[0.36,1.36]$ \\
\hline $\begin{array}{l}2 \text { Patient outcomes: depres- } \\
\text { sion (HADS lower score = bet- } \\
\text { ter } 0-21) \text { (9-24months) }\end{array}$ & 6 & & Odds Ratio (Random, 95\% Cl) & $0.79[0.51,1.23]$ \\
\hline
\end{tabular}




\begin{tabular}{|c|c|c|c|c|}
\hline Outcome or subgroup title & $\begin{array}{l}\text { No. of } \\
\text { studies }\end{array}$ & $\begin{array}{l}\text { No. of } \\
\text { partici- } \\
\text { pants }\end{array}$ & Statistical method & Effect size \\
\hline 2.1 Cancer & 3 & & Odds Ratio (Random, 95\% Cl) & $0.80[0.23,2.71]$ \\
\hline $\begin{array}{l}2.2 \text { Inflammatory bowel dis- } \\
\text { ease }\end{array}$ & 1 & & Odds Ratio (Random, 95\% Cl) & $0.74[0.34,1.63]$ \\
\hline 2.3 Psoriasis & 1 & & Odds Ratio (Random, 95\% Cl) & $1.0[0.72,1.38]$ \\
\hline 2.4 Rheumatoid arthritis & 1 & & Odds Ratio (Random, 95\% Cl) & $0.39[0.16,0.96]$ \\
\hline $\begin{array}{l}3 \text { Patient outcomes: quality of } \\
\text { life (12-18 months) }\end{array}$ & 7 & 1486 & Std. Mean Difference (IV, Random, 95\% CI) & $0.12[-0.00,0.25]$ \\
\hline 3.1 Cancer & 2 & 296 & Std. Mean Difference (IV, Random, 95\% CI) & $-0.07[-0.33,0.20]$ \\
\hline 3.2 Asthma & 1 & 115 & Std. Mean Difference (IV, Random, 95\% CI) & $0.47[0.10,0.84]$ \\
\hline $\begin{array}{l}3.3 \text { Inflammatory bowel dis- } \\
\text { ease }\end{array}$ & 2 & 735 & Std. Mean Difference (IV, Random, 95\% CI) & $0.15[0.00,0.29]$ \\
\hline 3.4 Psoriasis & 1 & 147 & Std. Mean Difference (IV, Random, 95\% CI) & $-0.01[-0.33,0.31]$ \\
\hline 3.5 Rheumatoid arthritis & 1 & 193 & Std. Mean Difference (IV, Random, 95\% CI) & $0.21[-0.07,0.50]$ \\
\hline $\begin{array}{l}4 \text { Rheumatoid arthritis: dis- } \\
\text { ease activity (VAS and DAS 12- } \\
24 \text { months) }\end{array}$ & 2 & 375 & Std. Mean Difference (IV, Random, 95\% CI) & $-0.21[-0.41,-0.01]$ \\
\hline $\begin{array}{l}5 \text { Rheumatoid arthritis: self-ef- } \\
\text { ficacy (ASES 12-24 months) }\end{array}$ & 2 & 375 & Mean Difference (IV, Fixed, 95\% CI) & $4.95[0.57,9.34]$ \\
\hline $\begin{array}{l}6 \text { Rheumatoid arthritis: pain } \\
\text { (VAS } 12-24 \text { months) }\end{array}$ & 2 & 375 & Mean Difference (IV, Fixed, 95\% CI) & $-0.71[-1.17,-0.26]$ \\
\hline $\begin{array}{l}7 \text { Rheumatoid arthritis: dis- } \\
\text { ability (HAQ 12-24 months) }\end{array}$ & 2 & 375 & Mean Difference (IV, Fixed, 95\% CI) & $-0.06[-0.19,0.06]$ \\
\hline $\begin{array}{l}8 \text { Rheumatoid arthritis: patient } \\
\text { satisfaction }\end{array}$ & 2 & 375 & Std. Mean Difference (IV, Random, 95\% CI) & $0.05[-0.41,0.52]$ \\
\hline 9 Service utilisation (contacts) & & & Other data & No numeric data \\
\hline 10 Service utilisation (costs) & & & Other data & No numeric data \\
\hline 11 Missed appointments & 2 & 599 & Mean Difference (IV, Fixed, 95\% CI) & $-0.27[-0.42,-0.12]$ \\
\hline $\begin{array}{l}12 \text { Adverse event: relapses } \\
\text { (12-60 months) }\end{array}$ & 3 & 888 & Mean Difference (IV, Random, 95\% CI) & $-0.20[-0.54,0.14]$ \\
\hline $\begin{array}{l}12.1 \text { Inflammatory bowel dis- } \\
\text { ease }\end{array}$ & 2 & 624 & Mean Difference (IV, Random, 95\% CI) & $-0.4[-0.72,-0.08]$ \\
\hline 12.2 Cancer & 1 & 264 & Mean Difference (IV, Random, 95\% CI) & $0.03[-0.08,0.14]$ \\
\hline 13 Patient satisfaction & & & Other data & No numeric data \\
\hline
\end{tabular}




\begin{tabular}{|c|c|c|c|c|}
\hline Outcome or subgroup title & $\begin{array}{l}\text { No. of } \\
\text { studies }\end{array}$ & $\begin{array}{l}\text { No. of } \\
\text { partici- } \\
\text { pants }\end{array}$ & Statistical method & Effect size \\
\hline 13.1 Rheumatoid arthritis & & & Other data & No numeric data \\
\hline $\begin{array}{l}13.2 \text { Inflammatory bowel dis- } \\
\text { ease }\end{array}$ & & & Other data & No numeric data \\
\hline 13.3 Cancer & & & Other data & No numeric data \\
\hline 13.4 Psoriasis & & & Other data & No numeric data \\
\hline $\begin{array}{l}14 \text { Chronic obstructive pul- } \\
\text { monary disease: other out- } \\
\text { comes }\end{array}$ & & & Other data & No numeric data \\
\hline 15 Cancer: other outcomes & & & Other data & No numeric data \\
\hline $\begin{array}{l}16 \text { Inflammatory bowel dis- } \\
\text { ease: other outcomes }\end{array}$ & & & Other data & No numeric data \\
\hline 17 Psoriasis: other outcomes & & & Other data & No numeric data \\
\hline $\begin{array}{l}18 \text { Rheumatoid arthritis: other } \\
\text { outcomes }\end{array}$ & & & Other data & No numeric data \\
\hline 19 Asthma: other outcomes & & & Other data & No numeric data \\
\hline
\end{tabular}

\section{Analysis 1.1. Comparison 1 Patient-initiated appointment systems versus consultant-led appointment systems, Outcome 1 Patient outcomes: anxiety (HADS lower score = better 0-21) (12-24 months).}

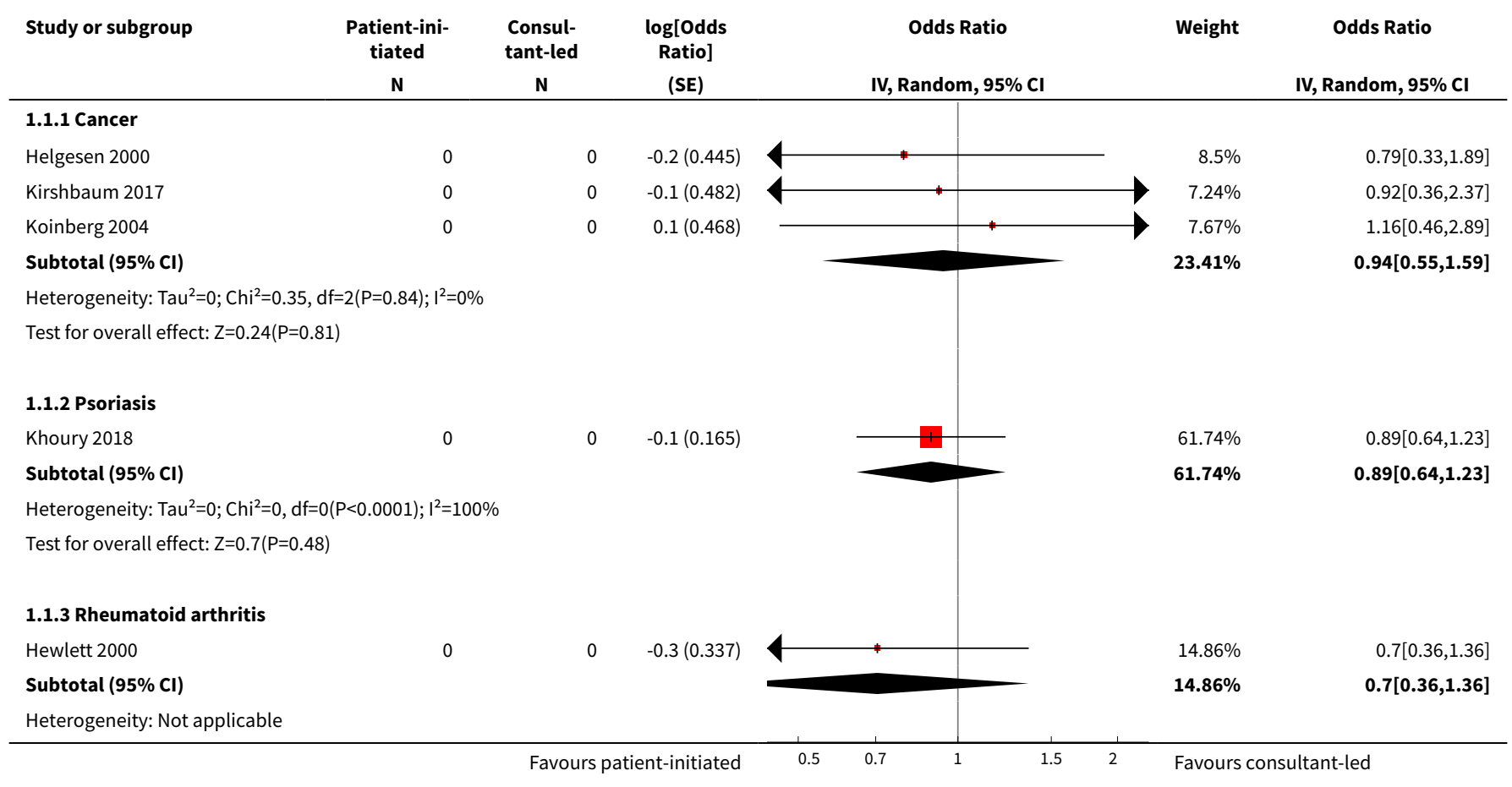




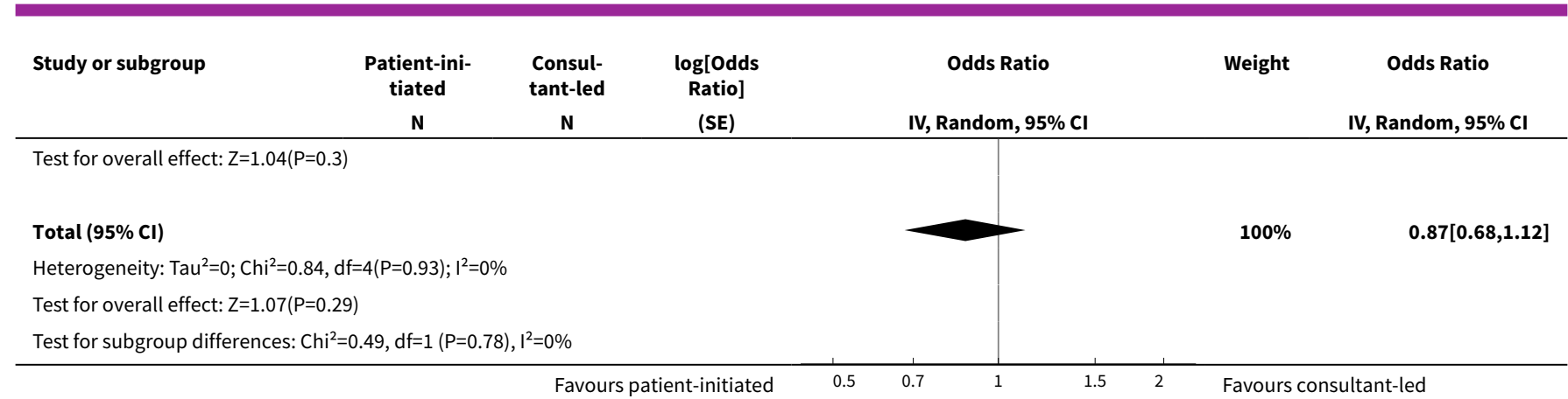

\section{Analysis 1.2. Comparison 1 Patient-initiated appointment systems versus consultant-led appointment systems, Outcome 2 Patient outcomes: depression (HADS lower score = better 0-21) (9-24months).}

\begin{tabular}{ccccc} 
Study or subgroup & $\begin{array}{c}\text { Patient-ini- } \\
\text { tiated }\end{array}$ & $\begin{array}{c}\text { Consul- } \\
\text { tant-led }\end{array}$ & $\begin{array}{c}\text { log[Odds } \\
\text { Ratio] }\end{array}$ & Odds Ratio \\
\hline N & N & (SE) & IV, Random, 95\% CI \\
\hline
\end{tabular}

\subsubsection{Cancer}

Helgesen 2000

Kirshbaum 2017

Koinberg 2004

(SE)

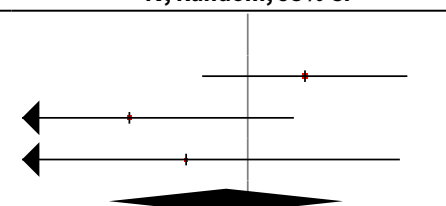

$12.85 \%$

$1.82[0.62,5.31]$

$0.6(0.547)$

$-1.2(0.879)$

$-0.6(1.14)$

$5.85 \%$

$0.29[0.05,1.62]$

$3.64 \%$

$0.53[0.06,4.91]$

Subtotal $(95 \% \mathrm{CI})$

Heterogeneity: $\operatorname{Tau}^{2}=0.51 ; \mathrm{Chi}^{2}=3.49, \mathrm{df}=2(\mathrm{P}=0.17) ; \mathrm{I}^{2}=42.68 \%$

Test for overall effect: $\mathrm{Z}=0.36(\mathrm{P}=0.72)$

\subsubsection{Inflammatory bowel disease}

Kennedy 2003

0

$0 \quad-0.3(0.403)$

Subtotal $(95 \% \mathrm{Cl})$

(n)

(a)

Heterogeneity: Not applicable

Test for overall effect: $Z=0.75(P=0.45)$

\subsubsection{Psoriasis}

Khoury 2018

Subtotal $(95 \% \mathrm{Cl})$

0

$0 \quad 0(0.165)$

$22.34 \%$

$0.8[0.23,2.71]$

Heterogeneity: Not applicable

Test for overall effect: Not applicable

\subsubsection{Rheumatoid arthritis}

Hewlett 2000

0

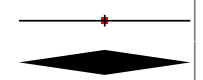

$16.65 \%$

$0.39[0.16,0.96]$

Subtotal $(95 \% \mathrm{Cl})$

Heterogeneity: Not applicable

Test for overall effect: $Z=2.06(P=0.04)$

\section{Total $(95 \% \mathrm{Cl})$}

Heterogeneity: $\mathrm{Tau}^{2}=0.1 ; \mathrm{Chi}^{2}=7.51, \mathrm{df}=5(\mathrm{P}=0.19) ; \mathrm{I}^{2}=33.46 \%$

Test for overall effect: $\mathrm{Z}=1.05(\mathrm{P}=0.3)$

Test for subgroup differences: $\mathrm{Chi}^{2}=3.98, \mathrm{df}=1(\mathrm{P}=0.26), \mathrm{I}^{2}=24.67 \%$ 
Analysis 1.3. Comparison 1 Patient-initiated appointment systems versus consultantled appointment systems, Outcome 3 Patient outcomes: quality of life (12-18 months).

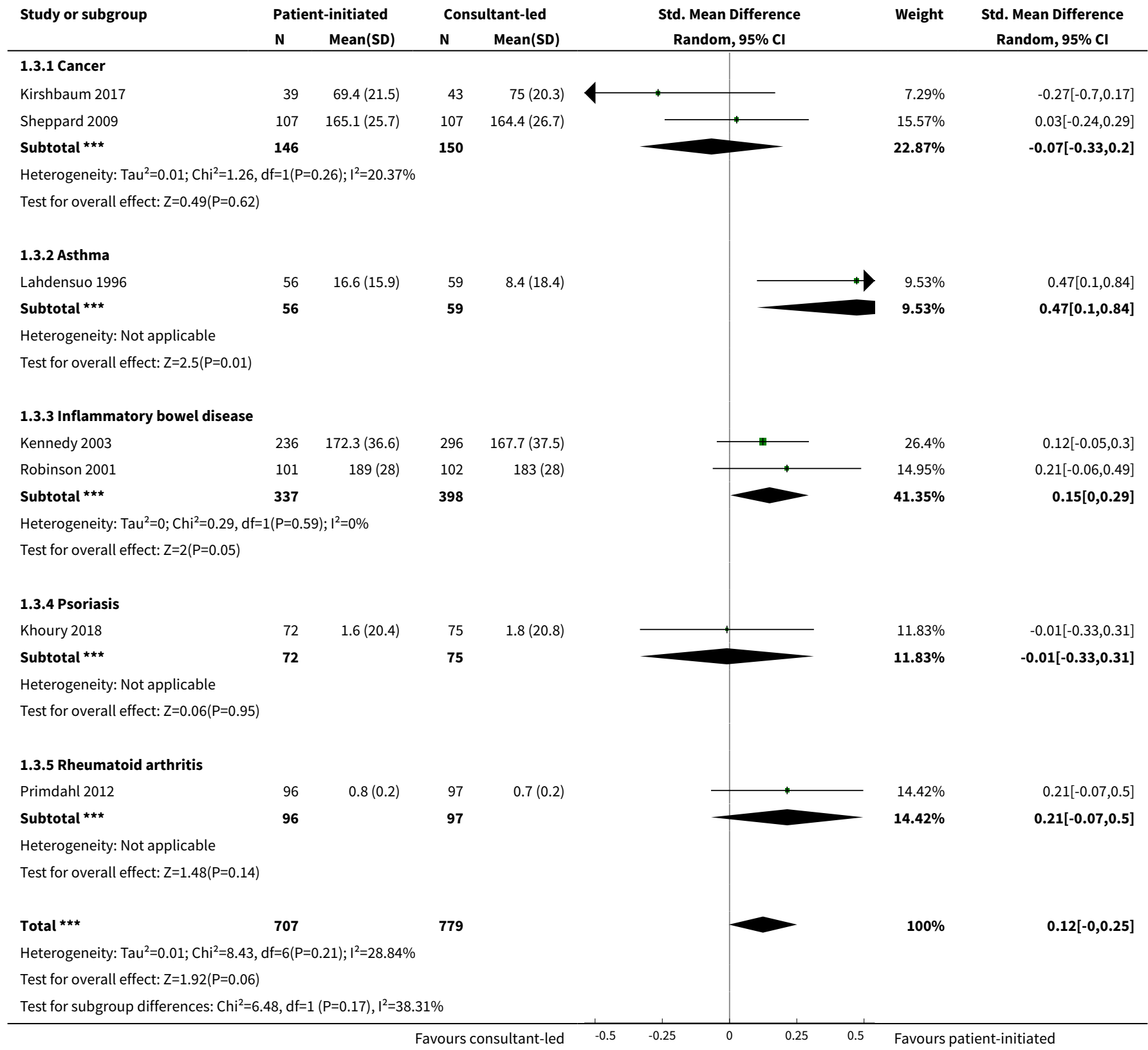

Analysis 1.4. Comparison 1 Patient-initiated appointment systems versus consultant-led appointment systems, Outcome 4 Rheumatoid arthritis: disease activity (VAS and DAS 12-24 months).

\begin{tabular}{|c|c|c|c|c|c|c|c|}
\hline \multirow[t]{2}{*}{ Study or subgroup } & \multicolumn{2}{|c|}{ Patient-initiated } & \multicolumn{2}{|c|}{ Consultant-led } & \multirow{2}{*}{$\begin{array}{c}\text { Std. Mean Difference } \\
\text { Random, } 95 \% \mathrm{Cl}\end{array}$} & \multirow[t]{2}{*}{ Weight } & \multirow{2}{*}{$\begin{array}{c}\text { Std. Mean Difference } \\
\text { Random, } 95 \% \mathrm{Cl}\end{array}$} \\
\hline & $\mathbf{N}$ & $\operatorname{Mean}(S D)$ & $\mathbf{N}$ & $\operatorname{Mean}(\mathrm{SD})$ & & & \\
\hline Hewlett 2000 & 93 & $3(2.3)$ & 89 & $3.5(2.3)$ & ب- & $48.57 \%$ & $-0.19[-0.48,0.1]$ \\
\hline Primdahl 2012 & 96 & $2.4(1.1)$ & 97 & $2.7(1.1)$ & +1 & $51.43 \%$ & $-0.23[-0.51,0.05]$ \\
\hline \multirow[t]{2}{*}{ Total $\star \star \star$} & 189 & & 186 & & & $100 \%$ & $-0.21[-0.41,-0.01]$ \\
\hline & & & TS & initiated & $\begin{array}{ll}-1 & -0.5\end{array}$ & Favours & ultant-led \\
\hline
\end{tabular}




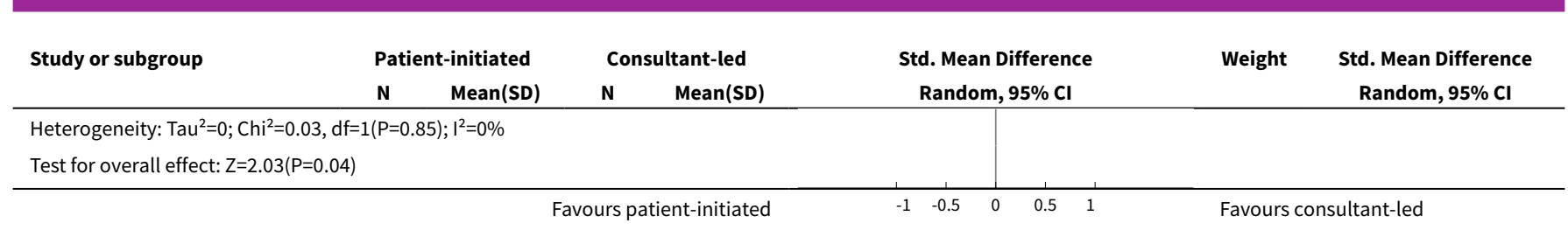

Analysis 1.5. Comparison 1 Patient-initiated appointment systems versus consultant-led appointment systems, Outcome 5 Rheumatoid arthritis: self-efficacy (ASES 12-24 months).

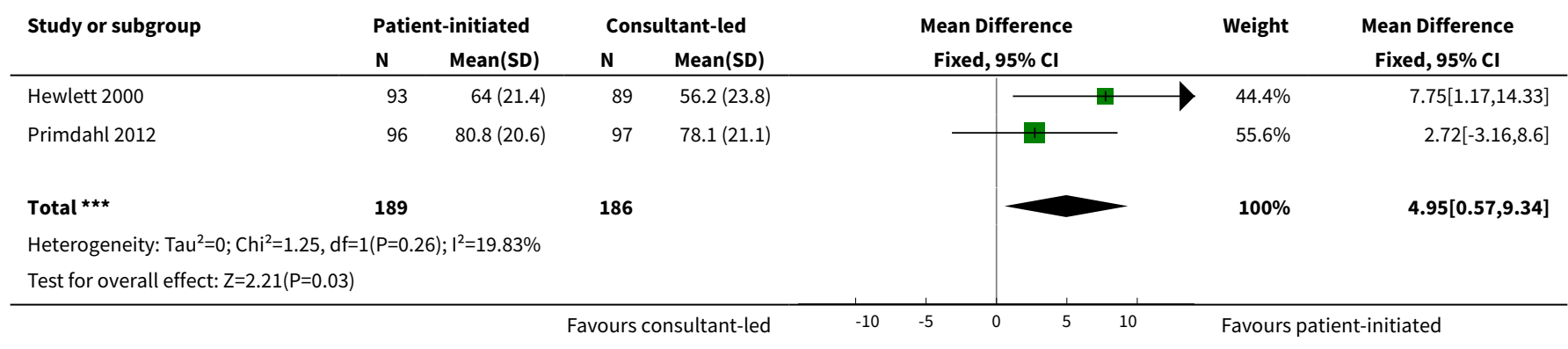

Analysis 1.6. Comparison 1 Patient-initiated appointment systems versus consultantled appointment systems, Outcome 6 Rheumatoid arthritis: pain (VAS 12-24 months).

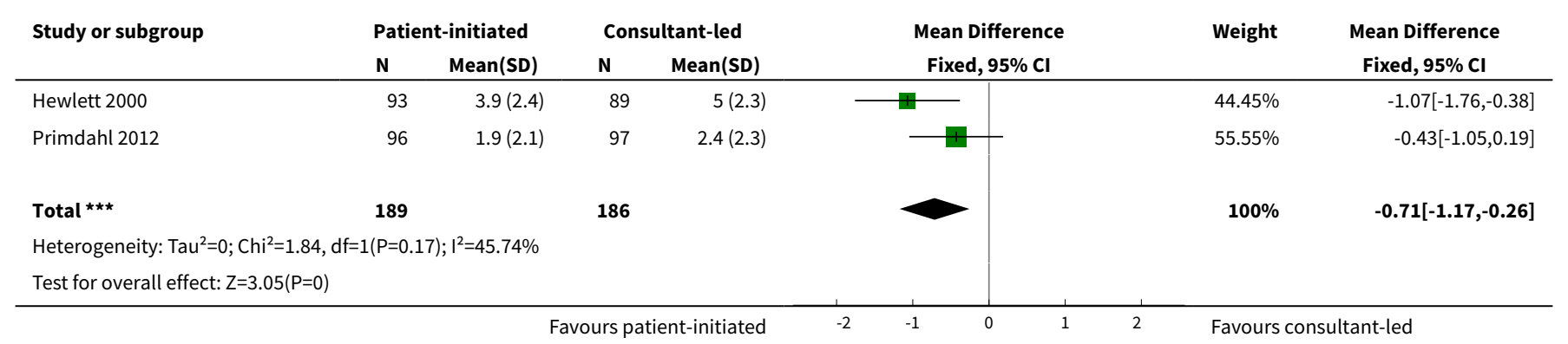

Analysis 1.7. Comparison 1 Patient-initiated appointment systems versus consultantled appointment systems, Outcome 7 Rheumatoid arthritis: disability (HAQ 12-24 months).

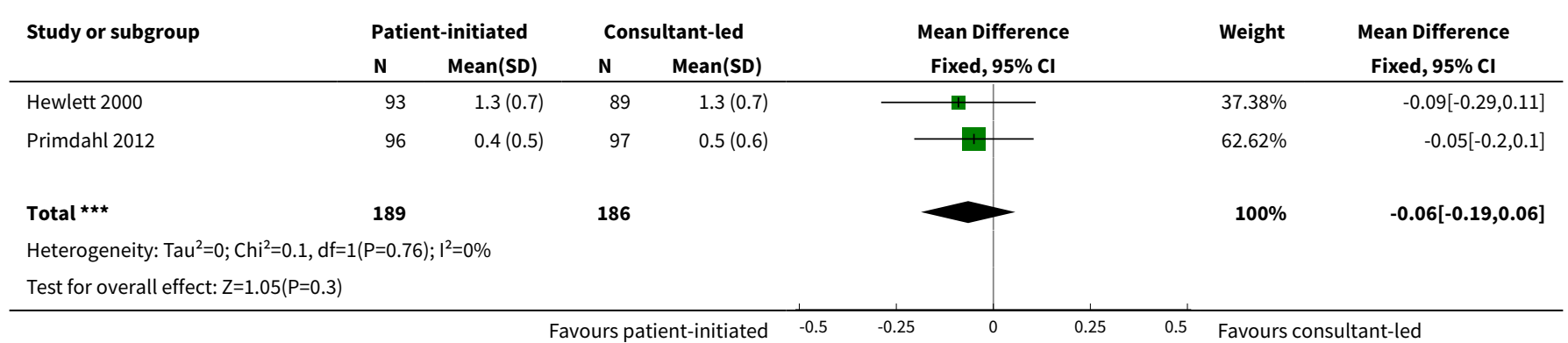


Analysis 1.8. Comparison 1 Patient-initiated appointment systems versus consultantled appointment systems, Outcome 8 Rheumatoid arthritis: patient satisfaction.

\begin{tabular}{|c|c|c|c|c|c|c|c|}
\hline \multirow[t]{2}{*}{ Study or subgroup } & \multicolumn{2}{|c|}{ Patient-initiated } & \multicolumn{2}{|c|}{ Consultant-led } & \multirow{2}{*}{$\begin{array}{c}\text { Std. Mean Difference } \\
\text { Random, } 95 \% \mathrm{Cl}\end{array}$} & \multirow[t]{2}{*}{ Weight } & \multirow{2}{*}{$\begin{array}{c}\text { Std. Mean Difference } \\
\text { Random, } 95 \% \mathrm{Cl}\end{array}$} \\
\hline & $\mathbf{N}$ & Mean(SD) & $\mathbf{N}$ & Mean(SD) & & & \\
\hline Hewlett 2000 & 93 & $8.2(2)$ & 89 & $7.6(2.1)$ & +1 & $49.69 \%$ & $0.29[-0,0.58]$ \\
\hline Primdahl 2012 & 96 & $77.9(23.8)$ & 97 & $82.1(21.3)$ & \begin{tabular}{l|l}
11 &
\end{tabular} & $50.31 \%$ & $-0.18[-0.47,0.1]$ \\
\hline 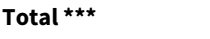 & 189 & & 186 & & & $100 \%$ & $0.05[-0.41,0.52]$ \\
\hline \multicolumn{8}{|c|}{ Heterogeneity: $\operatorname{Tau}^{2}=0.09 ; \mathrm{Chi}^{2}=5.22, \mathrm{df}=1(\mathrm{P}=0.02) ; \mathrm{I}^{2}=80.85 \%$} \\
\hline
\end{tabular}

Analysis 1.9. Comparison 1 Patient-initiated appointment systems versus consultant-led appointment systems, Outcome 9 Service utilisation (contacts).

\begin{tabular}{|c|c|c|c|c|c|c|c|c|}
\hline \multicolumn{9}{|c|}{ Service utilisation (contacts) } \\
\hline Study & $\begin{array}{c}\text { Consul- } \\
\text { tant-led n }\end{array}$ & Person-years & Total contacts & $\begin{array}{c}\text { Patient-ini- } \\
\text { tiated n }\end{array}$ & Person years & Total contacts & Rate ratio & $\begin{array}{l}\text { Contacts } \\
\text { covered }\end{array}$ \\
\hline Brown 2002 & 26 & 26 & 4 & 28 & 28 & 6 & 0.72 & $\begin{array}{l}\text { Total tele- } \\
\text { phone calls } \\
\text { and referrals to } \\
\text { hospital }\end{array}$ \\
\hline $\begin{array}{l}\text { Fredriksson } \\
2016\end{array}$ & 60 & 90 & 185 & 61 & 92 & 165 & 0.87 & $\begin{array}{l}\text { Consultant ap- } \\
\text { pointments on } \\
\text { ly }\end{array}$ \\
\hline Goodwin 2016 & 152 & 152 & 143 & 138 & 138 & 140 & 0.93 & $\begin{array}{l}\text { Telephone } \\
\text { contacts, face- } \\
\text { to-face ap- } \\
\text { pointments } \\
\text { nurse/consul- } \\
\text { tant }\end{array}$ \\
\hline Gulliford 1997 & 96 & 128 & 57 & 97 & 129 & 61 & 0.94 & $\begin{array}{l}\text { Contacts by } \\
\text { telephone, } \\
\text { clinic appoint- } \\
\text { ments, GP vis- } \\
\text { its }\end{array}$ \\
\hline Helgesen 2000 & 200 & 600 & 2728 & 200 & 600 & 4028 & 0.68 & $\begin{array}{l}\text { Telephone } \\
\text { calls, hospital } \\
\text { and GP visits, } \\
\text { primary care } \\
\text { nurse visits, } \\
\text { other outpa- } \\
\text { tient contacts }\end{array}$ \\
\hline Hewlett 2000 & 89 & 178 & 2178 & 93 & 186 & 1955 & 1.16 & $\begin{array}{l}\text { Hospital doc- } \\
\text { tor, GP, nurse, } \\
\text { occupation- } \\
\text { al therapist, } \\
\text { physiothera- } \\
\text { pist, podiatrist, } \\
\text { orthopaedic } \\
\text { surgeon, or- } \\
\text { thotics }\end{array}$ \\
\hline Jeppesen 2018 & 77 & 64 & 291 & 79 & 66 & 269 & 1.13 & $\begin{array}{l}\text { All cancer-re- } \\
\text { lated GP and } \\
\text { gynaecolo- } \\
\text { gist visits, tele- } \\
\text { phone calls } \\
\text { and examina- } \\
\text { tions at gynae- } \\
\text { cology depart- } \\
\text { ment }\end{array}$ \\
\hline Kennedy 2003 & 366 & 366 & 2164 & 285 & 285 & 1166 & 1.45 & $\begin{array}{l}\text { GP, disease-re- } \\
\text { lated outpa- } \\
\text { tients, other } \\
\text { outpatients }\end{array}$ \\
\hline
\end{tabular}




\begin{tabular}{|c|c|c|c|c|c|c|c|c|}
\hline \multicolumn{9}{|c|}{ Service utilisation (contacts) } \\
\hline Study & $\begin{array}{l}\text { Consul- } \\
\text { tant-led n }\end{array}$ & Person-years & Total contacts & $\begin{array}{l}\text { Patient-ini- } \\
\text { tiated n }\end{array}$ & Person years & Total contacts & Rate ratio & $\begin{array}{l}\text { Contacts } \\
\text { covered }\end{array}$ \\
\hline Khoury 2018 & 75 & 75 & 409 & 72 & 72 & 197 & 1.99 & $\begin{array}{l}\text { Consultations } \\
\text { with derma- } \\
\text { tologist and } \\
\text { telephone (not } \\
\text { medication } \\
\text { collection or } \\
\text { tests) }\end{array}$ \\
\hline Koinberg 2004 & 131 & 655 & 1172 & 133 & 665 & 1023 & 1.16 & $\begin{array}{l}\text { Physician and } \\
\text { nurse visits, } \\
\text { telephone } \\
\text { calls, other } \\
\text { consultations }\end{array}$ \\
\hline $\begin{array}{l}\text { Lahdensuo } \\
1996\end{array}$ & 59 & 59 & 59 & 56 & 56 & 28 & 2.00 & $\begin{array}{l}\text { Outpatient vis- } \\
\text { its only }\end{array}$ \\
\hline Primdahl 2012 & 97 & 194 & 3430 & 96 & 192 & 3116 & 1.09 & $\begin{array}{l}\text { Rheumatolo- } \\
\text { gist, nurse GP } \\
\text { consultations, } \\
\text { GP telephone } \\
\text { call }\end{array}$ \\
\hline Robinson 2001 & 102 & 119 & 344 & 101 & 118 & 89 & 3.83 & $\begin{array}{l}\text { Booked clinic } \\
\text { appointments }\end{array}$ \\
\hline Sheppard 2009 & 112 & 168 & 90 & 112 & 168 & 92 & 0.98 & $\begin{array}{l}\text { Specialist nurs- } \\
\text { es and GPs } \\
\text { contacts }\end{array}$ \\
\hline Williams 2000 & 78 & 156 & 1062 & 77 & 154 & 1136 & 0.92 & $\begin{array}{l}\text { Outpatient vis- } \\
\text { its, day cases, } \\
\text { inpatient days, } \\
\text { GP surgery/ } \\
\text { home visits }\end{array}$ \\
\hline
\end{tabular}

Analysis 1.10. Comparison 1 Patient-initiated appointment systems versus consultant-led appointment systems, Outcome 10 Service utilisation (costs).

\begin{tabular}{|c|c|c|c|c|c|c|c|c|c|c|}
\hline \multicolumn{11}{|c|}{ Service utilisation (costs) } \\
\hline Study & $\begin{array}{l}\text { Consul- } \\
\text { tant-led n }\end{array}$ & $\begin{array}{c}\text { Mean cost } \\
\text { per patient }\end{array}$ & SD & $\begin{array}{c}\text { Mean cost } \\
\text { per patient } \\
\text { per year }\end{array}$ & $\begin{array}{c}\text { Pa- } \\
\text { tient-ini- } \\
\text { tiated } n\end{array}$ & $\begin{array}{l}\text { Mean cost } \\
\text { per patient }\end{array}$ & SD & $\begin{array}{c}\text { Mean cost } \\
\text { per patient } \\
\text { per year }\end{array}$ & $\begin{array}{c}\text { Mean dif- } \\
\text { ference } \\
\text { (per pa- } \\
\text { tient-year) }\end{array}$ & $\begin{array}{l}\text { Costs } \\
\text { covered } \\
\text { (exclud- } \\
\text { ing med- } \\
\text { ication) } \\
\text { (currency) }\end{array}$ \\
\hline $\begin{array}{l}\text { Berkhof } \\
2014\end{array}$ & 51 & 2321 & 3967 & 1160.5 & 49 & 1803 & 2617 & 901.5 & -259 & $\begin{array}{l}\text { GP, pulmo- } \\
\text { nologist, } \\
\text { pulmonary } \\
\text { nurse } \\
\text { emergency } \\
\text { depart- } \\
\text { ment, pul- } \\
\text { monary } \\
\text { ward (EUR) }\end{array}$ \\
\hline $\begin{array}{l}\text { Goodwin } \\
2016\end{array}$ & 152 & 32.21 & 22.15 & 32.21 & 138 & 34.72 & 34.51 & 34.72 & 2.51 & $\begin{array}{l}\text { Telephone, } \\
\text { face-to-face } \\
\text { nurse and } \\
\text { consultant } \\
\text { (GBP) }\end{array}$ \\
\hline $\begin{array}{l}\text { Helgesen } \\
2000\end{array}$ & 200 & 15280 & - & 3056 & 200 & 12873 & - & 2574.6 & -481.4 & $\begin{array}{l}\text { Outpatients } \\
\text { costs, hos- } \\
\text { pital, nurs- } \\
\text { ing home } \\
\text { and hospi- } \\
\text { tal-based } \\
\text { home care } \\
\text { (SEK) }\end{array}$ \\
\hline $\begin{array}{l}\text { Hewlett } \\
2000\end{array}$ & 89 & 624.69 & 339.48 & 312.345 & 93 & 436.94 & 332.76 & 218.47 & -93.88 & $\begin{array}{l}\text { Hospital } \\
\text { consul- } \\
\text { tants, oc- } \\
\text { cupation- } \\
\text { al thera- }\end{array}$ \\
\hline
\end{tabular}




\begin{tabular}{|c|c|c|c|c|c|c|c|c|c|c|}
\hline \multicolumn{11}{|c|}{ Service utilisation (costs) } \\
\hline Study & $\begin{array}{l}\text { Consul- } \\
\text { tant-led n }\end{array}$ & $\begin{array}{c}\text { Mean cost } \\
\text { per patient }\end{array}$ & SD & $\begin{array}{c}\text { Mean cost } \\
\text { per patient } \\
\text { per year }\end{array}$ & $\begin{array}{c}\text { Pa- } \\
\text { tient-ini- } \\
\text { tiated } n\end{array}$ & $\begin{array}{c}\text { Mean cost } \\
\text { per patient }\end{array}$ & SD & $\begin{array}{c}\text { Mean cost } \\
\text { per patient } \\
\text { per year }\end{array}$ & $\begin{array}{c}\text { Mean dif- } \\
\text { ference } \\
\text { (per pa- } \\
\text { tient-year) }\end{array}$ & $\begin{array}{c}\text { Costs } \\
\text { covered } \\
\text { (exclud- } \\
\text { ing med- } \\
\text { ication) } \\
\text { (currency) }\end{array}$ \\
\hline & & & & & & & & & & $\begin{array}{l}\text { py, physio- } \\
\text { therapy, or- } \\
\text { thoptist, or- } \\
\text { thopaedic } \\
\text { sur- } \\
\text { geon, chi- } \\
\text { ropodist, } \\
\text { transport, } \\
\text { including } \\
\text { predicted } \\
\text { GBP } 2000 \\
\text { nurse cost } \\
\text { for helpline } \\
\text { (GBP) }\end{array}$ \\
\hline $\begin{array}{l}\text { Kennedy } \\
2003\end{array}$ & 366 & 494.99 & - & 494.99 & 285 & 364.78 & - & 364.78 & -130.21 & $\begin{array}{l}\text { GP and all } \\
\text { outpatient } \\
\text { visits, hotel } \\
\text { cost per in- } \\
\text { patient day, } \\
\text { interven- } \\
\text { tion (GBP) }\end{array}$ \\
\hline $\begin{array}{l}\text { Koinberg } \\
2004\end{array}$ & 131 & - & - & 630 & 133 & - & - & 495 & -135 & $\begin{array}{l}\text { Nurse, GP, } \\
\text { physiother- } \\
\text { apist, so- } \\
\text { cial worker, } \\
\text { prosthet- } \\
\text { ic techni- } \\
\text { cians, plus } \\
\text { tests and } \\
\text { telephone } \\
\text { contacts } \\
\text { (EUR) }\end{array}$ \\
\hline $\begin{array}{l}\text { Primdahl } \\
2012\end{array}$ & 97 & 1225 & 522 & 612.5 & 96 & 1085 & 362 & 542.5 & -70 & $\begin{array}{l}\text { Face-to- } \\
\text { face and } \\
\text { phone } \\
\text { appoint- } \\
\text { ments, } \\
\text { tests, oth- } \\
\text { er prima- } \\
\text { ry care ser- } \\
\text { vices not } \\
\text { disclosed } \\
\text { (EUR) }\end{array}$ \\
\hline $\begin{array}{l}\text { Williams } \\
2000\end{array}$ & 78 & 688 & - & 344 & 77 & 670 & - & 335 & 47.5 & $\begin{array}{l}\text { Outpatient } \\
\text { visits, tests, } \\
\text { day cases, } \\
\text { inpatient } \\
\text { days, GP } \\
\text { visits, home } \\
\text { visits (GBP) }\end{array}$ \\
\hline
\end{tabular}

Analysis 1.11. Comparison 1 Patient-initiated appointment systems versus consultant-led appointment systems, Outcome 11 Missed appointments.

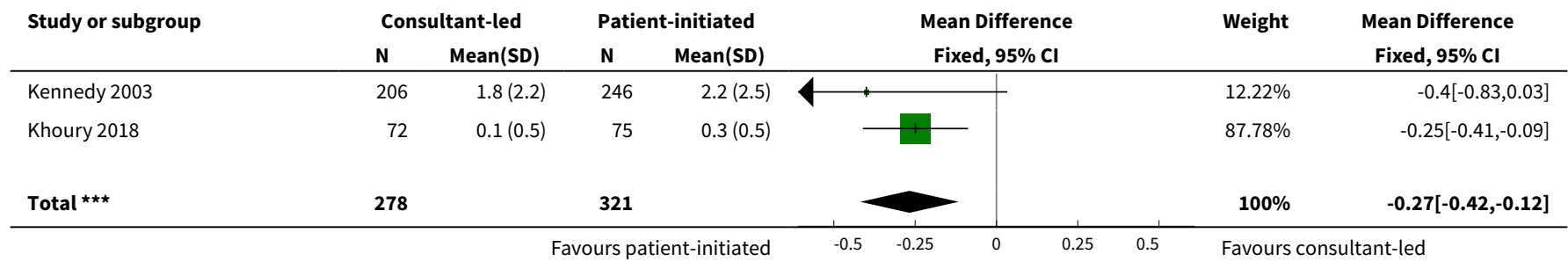




\begin{tabular}{|c|c|c|c|c|c|c|c|c|c|}
\hline \multirow[t]{2}{*}{ Study or subgroup } & \multicolumn{2}{|c|}{ Consultant-led } & \multicolumn{2}{|c|}{ Patient-initiated } & \multirow{2}{*}{\multicolumn{3}{|c|}{$\begin{array}{c}\text { Mean Difference } \\
\text { Fixed, } 95 \% \mathrm{Cl}\end{array}$}} & \multirow[t]{2}{*}{ Weight } & \multirow{2}{*}{$\begin{array}{c}\text { Mean Difference } \\
\text { Fixed, } 95 \% \mathrm{Cl}\end{array}$} \\
\hline & $\mathbf{N}$ & Mean(SD) & $\mathbf{N}$ & Mean(SD) & & & & & \\
\hline \multicolumn{10}{|c|}{ Heterogeneity: $\mathrm{Tau}^{2}=0 ; \mathrm{Chi}^{2}=0.41, \mathrm{df}=1(\mathrm{P}=0.52) ; \mathrm{I}^{2}=0 \%$} \\
\hline \multicolumn{10}{|c|}{ Test for overall effect: $Z=3.46(P=0)$} \\
\hline & & & urc & ent-initiated & -0.5 & -0.25 & 0.25 & Favours & Itant-led \\
\hline
\end{tabular}

\section{Analysis 1.12. Comparison 1 Patient-initiated appointment systems versus consultant- led appointment systems, Outcome 12 Adverse event: relapses (12-60 months).}

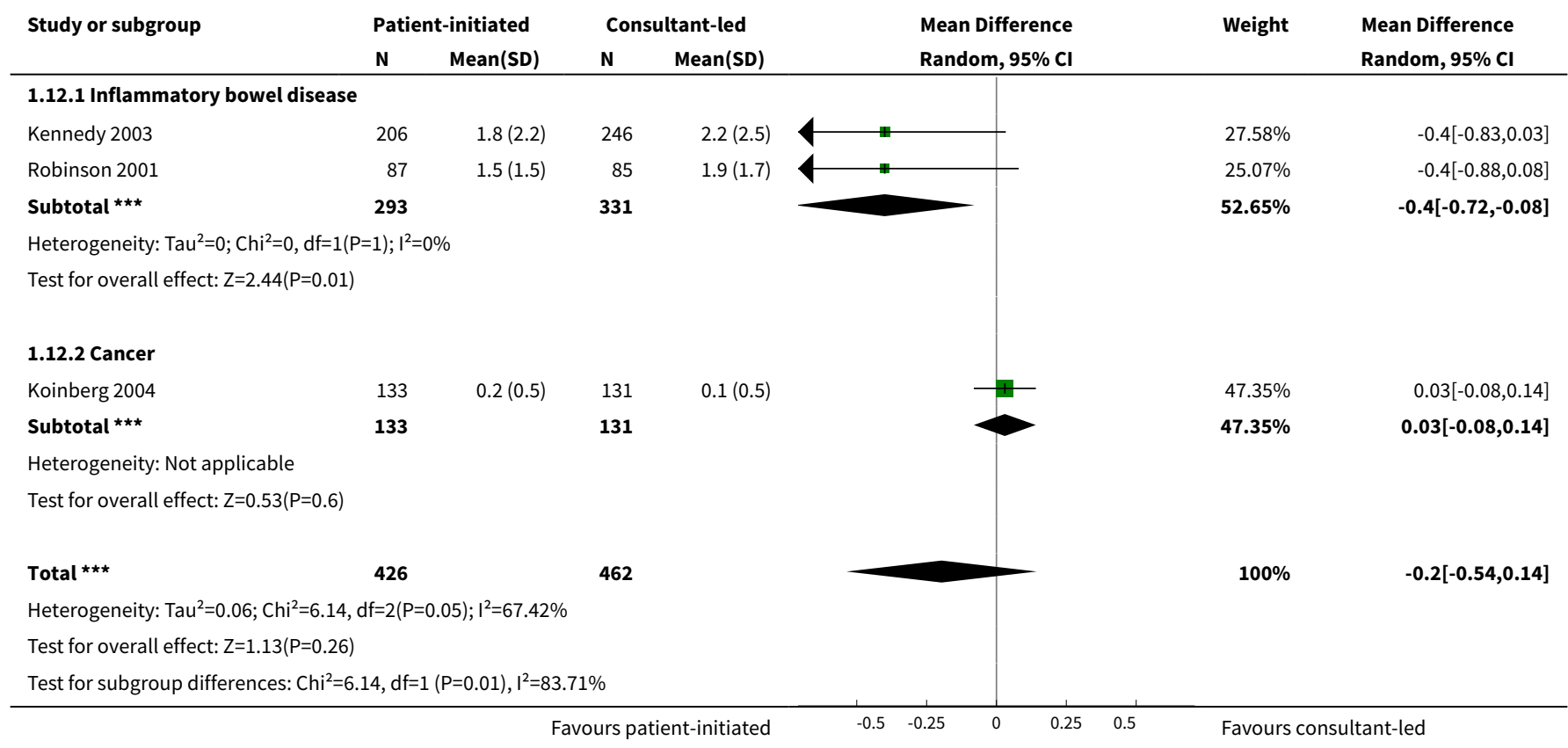

\section{Analysis 1.13. Comparison 1 Patient-initiated appointment systems versus consultant-led appointment systems, Outcome 13 Patient satisfaction.}

\begin{tabular}{|c|c|c|c|c|c|c|}
\hline \multicolumn{7}{|c|}{ Patient satisfaction } \\
\hline Study & Outcome & $\begin{array}{c}\text { Patient-initiated } \\
\mathbf{n}\end{array}$ & $\begin{array}{c}\text { Patient-initiated } \\
\text { mean (SE) }\end{array}$ & $\begin{array}{c}\text { Consultant-led } \\
\mathbf{n}\end{array}$ & $\begin{array}{c}\text { Consultant-led } \\
\text { mean (SE) }\end{array}$ & $P$ value $(95 \% \mathrm{Cl})$ \\
\hline \multicolumn{7}{|c|}{ Rheumatoid arthritis } \\
\hline Fredriksson 2016 & $\begin{array}{l}\text { Satisfaction with } \\
\text { care at } 18 \text { months } \\
\text { (mean change from } \\
\text { baseline) }\end{array}$ & 64 & 1 & 67 & 1 & 0.47 \\
\hline Goodwin 2016 & $\begin{array}{l}\text { Satisfaction with ser- } \\
\text { vice at } 12 \text { months - } \\
\text { (mean score) }\end{array}$ & 138 & 100 & 152 & 80 & 0.002 \\
\hline \multicolumn{7}{|c|}{ Inflammatory bowel disease } \\
\hline Kennedy 2003 & $\begin{array}{l}\text { Satisfaction with } \\
\text { hospital visit (mean } \\
\text { score at } 12 \text { months } \\
\text { from patient diary) }\end{array}$ & 64 & 54.6 (SD 8.5) & 132 & 53.6 (SD 9.1) & $0.62(-3.67$ to 6.03$)$ \\
\hline Robinson 2001 & $\begin{array}{l}\text { Acceptability - pre- } \\
\text { ferred PIAS interven- } \\
\text { tion (at } 14 \text { months) }\end{array}$ & 86 & $71(82)$ & 85 & $80(95)$ & NR \\
\hline Williams 2000 & $\begin{array}{l}\text { Acceptability - pre- } \\
\text { ferred PIAS interven- } \\
\text { tion at ( } 24 \text { months) }\end{array}$ & 81 & $69(85)$ & 83 & $34(41)$ & $<0.01$ \\
\hline
\end{tabular}




\begin{tabular}{|c|c|c|c|c|c|c|}
\hline Study & Outcome & $\begin{array}{c}\text { Patient-initiated } \\
\mathbf{n} \\
\end{array}$ & $\begin{array}{c}\text { Patient satisfaction } \\
\text { Patient-initiated } \\
\text { mean (SE) } \\
\end{array}$ & $\begin{array}{c}\text { Consultant-led } \\
\mathbf{n}\end{array}$ & $\begin{array}{c}\text { Consultant-led } \\
\text { mean (SE) } \\
\end{array}$ & $P$ value $(95 \% \mathrm{CI})$ \\
\hline \multicolumn{7}{|c|}{ Cancer } \\
\hline Brown 2002 & $\begin{array}{l}\text { Satisfaction with al- } \\
\text { located intervention } \\
\text { (at } 6 \text { months) }\end{array}$ & 28 & $26(93)$ & 24 & $24(100)$ & NR \\
\hline Gulliford 1997 & $\begin{array}{l}\text { Acceptibility (\% pre- } \\
\text { ferring intervention) }\end{array}$ & 97 & 11 & 96 & 6 & NR \\
\hline Helgesen 2000 & $\begin{array}{l}\text { Reporting deficient } \\
\text { outpatient service } \\
\text { (at } 36 \text { months) }\end{array}$ & NR & NR (6.6) & NR & NR (4.9) & NR \\
\hline Koinberg 2004 & $\begin{array}{l}\text { Satisfied with med- } \\
\text { ical centre (SaaC at } \\
60 \text { months) }\end{array}$ & 133 & $122(91.6)$ & 131 & $130(98.9)$ & ns \\
\hline \multicolumn{7}{|c|}{ Psoriasis } \\
\hline
\end{tabular}

Analysis 1.14. Comparison 1 Patient-initiated appointment systems versus consultant-led appointment systems, Outcome 14 Chronic obstructive pulmonary disease: other outcomes.

\begin{tabular}{|c|c|c|c|c|c|c|}
\hline \multicolumn{7}{|c|}{ Chronic obstructive pulmonary disease: other outcomes } \\
\hline Study & Outcome & $\begin{array}{c}\text { Patient-initiated } \\
\mathbf{n}\end{array}$ & $\begin{array}{l}\text { Patient-initiated } \\
\text { mean change } \\
\text { from baseline (SE) }\end{array}$ & $\begin{array}{c}\text { Consultant-led } \\
n\end{array}$ & $\begin{array}{c}\text { Consultant-led } \\
\text { mean change } \\
\text { from baseline (SE) }\end{array}$ & $P$ value $(95 \% \mathrm{Cl})$ \\
\hline Berkhof 2014 & $\begin{array}{l}\text { Chronic obstructive } \\
\text { pulmonary disease } \\
\text { symptoms (Clini- } \\
\text { cal COPD Question- } \\
\text { naire range } 0-6 \text { low- } \\
\text { er score is better, } \\
\text { minimal clinically } \\
\text { important difference } \\
(\mathrm{MCID})=0.4)\end{array}$ & 40 & $0.33( \pm 0.11)$ & 29 & $0.53( \pm 0.13)$ & $0.24(-0.55$ to 0.14$)$ \\
\hline Berkhof 2014 & $\begin{array}{l}\text { Respiratory symp- } \\
\text { toms (St George's } \\
\text { Respiratory Ques- } \\
\text { tionnaire (SGRQ) } \\
\text { total score at } 24 \\
\text { months, range } 0-100 \\
\text { low score indicates } \\
\text { better health status, } \\
\text { MCID of SGRQ total } \\
\text { score = 4) }\end{array}$ & 38 & $5.0( \pm 2.2)$ & 30 & $6.4( \pm 2.4)$ & $0.67(-7.9$ to 5.1$)$ \\
\hline Berkhof 2014 & $\begin{array}{l}\text { Time to exacerba- } \\
\text { tion (median no. of } \\
\text { days) }\end{array}$ & 49 & $307( \pm 61.6)$ & 51 & $335( \pm 60.2)$ & 0.40 \\
\hline
\end{tabular}

Analysis 1.15. Comparison 1 Patient-initiated appointment systems versus consultant-led appointment systems, Outcome 15 Cancer: other outcomes.

\begin{tabular}{|c|c|c|c|c|c|c|}
\hline \multicolumn{7}{|c|}{ Cancer: other outcomes } \\
\hline Study & Outcome & $\begin{array}{l}\text { Patient-initiated } \\
\mathbf{n}\end{array}$ & $\begin{array}{c}\text { Patient-initiated } \\
(\%)\end{array}$ & $\begin{array}{c}\text { Consultant-led } \\
n\end{array}$ & $\begin{array}{c}\text { Consultant-led } \\
(\%)\end{array}$ & $P$ value $(95 \% \mathrm{CI})$ \\
\hline Gulliford 1997 & $\begin{array}{l}\% \text { reassured with } \\
\text { service (at } 16 \\
\text { months) }\end{array}$ & 97 & 88 & 96 & 94 & NR \\
\hline Gulliford 1997 & - & - & - & - & - & - \\
\hline Helgesen 2000 & $\begin{array}{l}\text { Accessibility (\% re- } \\
\text { porting service in- }\end{array}$ & 200 & 8.6 & 200 & 7.3 & RR 1.18 ( 0.46 to 3.03 ) \\
\hline
\end{tabular}




\begin{tabular}{|c|c|c|c|c|c|c|}
\hline \multicolumn{7}{|c|}{ Cancer: other outcomes } \\
\hline Study & Outcome & $\begin{array}{c}\text { Patient-initiated } \\
\mathbf{n}\end{array}$ & $\begin{array}{c}\text { Patient-initiated } \\
(\%)\end{array}$ & $\begin{array}{c}\text { Consultant-led } \\
n\end{array}$ & $\begin{array}{c}\text { Consultant-led } \\
(\%)\end{array}$ & $\mathrm{P}$ value $(95 \% \mathrm{Cl})$ \\
\hline & $\begin{array}{l}\text { accessible by tele- } \\
\text { phone } 36 \text { months) }\end{array}$ & & & & & \\
\hline Helgesen 2000 & - & - & - & - & - & - \\
\hline Jeppesen 2018 & $\begin{array}{l}\text { Fear of cancer recur- } \\
\text { rence at } 10 \text { months } \\
\text { (mean (SD)) }\end{array}$ & 105 & $43.4(26.5)$ & 107 & $40.5(28.5)$ & 0.02 \\
\hline Jeppesen 2018 & $\begin{array}{l}\text { Clinical fear of recur- } \\
\text { rence at } 10 \text { months } \\
(\%)\end{array}$ & 105 & 17.7 & 107 & 22.1 & 0.89 \\
\hline Koinberg 2004 & $\begin{array}{l}\text { Accessibility by tele- } \\
\text { phone at } 60 \text { months } \\
(\%)\end{array}$ & 133 & 100 & 131 & 96.5 & ns \\
\hline Koinberg 2004 & - & - & - & - & - & - \\
\hline Sheppard 2009 & $\begin{array}{l}\text { Isolation (\% felt iso- } \\
\text { lated) }\end{array}$ & 107 & 14 & 107 & 9 & 0.245 \\
\hline
\end{tabular}

Analysis 1.16. Comparison 1 Patient-initiated appointment systems versus consultantled appointment systems, Outcome 16 Inflammatory bowel disease: other outcomes.

\begin{tabular}{|c|c|c|c|c|c|c|}
\hline \multicolumn{7}{|c|}{ Inflammatory bowel disease: other outcomes } \\
\hline Study & Outcome & $\begin{array}{c}\text { Patient-initiated } \\
\mathbf{n}\end{array}$ & $\begin{array}{c}\text { Patient-initiated } \\
\text { mean (SD) }\end{array}$ & $\begin{array}{c}\text { Consultant-led } \\
\mathbf{n}\end{array}$ & $\begin{array}{c}\text { Consultant-led } \\
\text { mean (SD) }\end{array}$ & $\begin{array}{c}\mathrm{P} \text { value/mean } \\
\text { difference }(95 \% \mathrm{CI})\end{array}$ \\
\hline Kennedy 2003 & $\begin{array}{l}\text { Enablement after } \\
\text { initial consultation }\end{array}$ & 260 & $4.0(3.9)$ & 352 & $3.0(3.9)$ & 0.026 (0.12 to 1.68$)$ \\
\hline Kennedy 2003 & $\begin{array}{l}\text { Delay before starting } \\
\text { treatment (\% within } \\
1 \text { day) }\end{array}$ & 81 & 49.7 & 109 & 50.6 & 0.95 (-0.52 to 0.49$)$ \\
\hline Kennedy 2003 & $\begin{array}{l}\text { Appointments made } \\
\text { by patient (\% at } \\
\text { least } 1 \text { self-made ap- } \\
\text { pointment) }\end{array}$ & 144 & 43 & 250 & 22 & $<0.001$ (1.63 to 4.46$)$ \\
\hline Robinson 2001 & $\begin{array}{l}\text { Time to symptom } \\
\text { treatment (hours) }\end{array}$ & 101 & 14.8 & 102 & 49.6 & $<0.0001$ \\
\hline Robinson 2001 & $\begin{array}{l}\text { Cost to patient (GBP) } \\
\text { at } 14 \text { months }\end{array}$ & 101 & 0.86 & 102 & 8.92 & $<0.0001$ \\
\hline Robinson 2001 & - & - & - & - & - & - \\
\hline
\end{tabular}

Analysis 1.17. Comparison 1 Patient-initiated appointment systems versus consultant-led appointment systems, Outcome 17 Psoriasis: other outcomes.

\begin{tabular}{|c|c|c|c|c|c|c|}
\hline \multicolumn{7}{|c|}{ Psoriasis: other outcomes } \\
\hline Study & Outcome & $\begin{array}{c}\text { Patient-initiated } \\
\text { N }\end{array}$ & $\begin{array}{c}\text { Patient-initiated } \\
\text { m (SD) }\end{array}$ & $\begin{array}{c}\text { Consultant-led } \\
\text { N } \\
\end{array}$ & $\begin{array}{c}\text { Consultant-led } \\
\text { m (SD) }\end{array}$ & $\begin{array}{l}p \text { value or mean } \\
\text { diff }(95 \% \mathrm{Cl})\end{array}$ \\
\hline Khoury 2018 & $\begin{array}{l}\text { Missed medica- } \\
\text { tion collection (at } \\
12 \mathrm{mths} \text { ) }\end{array}$ & 72 & $11(8.2)$ & 75 & $4(4)$ & $\begin{array}{l}-0.10(-0.024 \text { to } \\
-0.04)\end{array}$ \\
\hline Khoury 2018 & $\begin{array}{l}\text { Missed laboratory } \\
\text { tests (at 12mths) }\end{array}$ & 72 & $16(13.8)$ & 75 & $14(18)$ & $-0 \cdot 10(-0.20$ to $0 \cdot 18)$ \\
\hline Khoury 2018 & $\begin{array}{l}\text { Changes in medica- } \\
\text { tion (at } 12 \text { mths) }\end{array}$ & 72 & $6.8 \%$ & 75 & $20.6 \%$ & $p<0.001$ \\
\hline Khoury 2018 & $\begin{array}{l}\text { Disease activity at } \\
12 \mathrm{mths} \text { (Psoriasis } \\
\text { Area and Severity In- } \\
\text { dex - PASI) }\end{array}$ & 72 & $0.1(\mathrm{SE}+/-0.2)$ & 75 & $-0.16(\mathrm{SE}+/-0.2)$ & $-0.24,(-0.84$ to 0.36$)$ \\
\hline
\end{tabular}


Analysis 1.18. Comparison 1 Patient-initiated appointment systems versus consultantled appointment systems, Outcome 18 Rheumatoid arthritis: other outcomes.

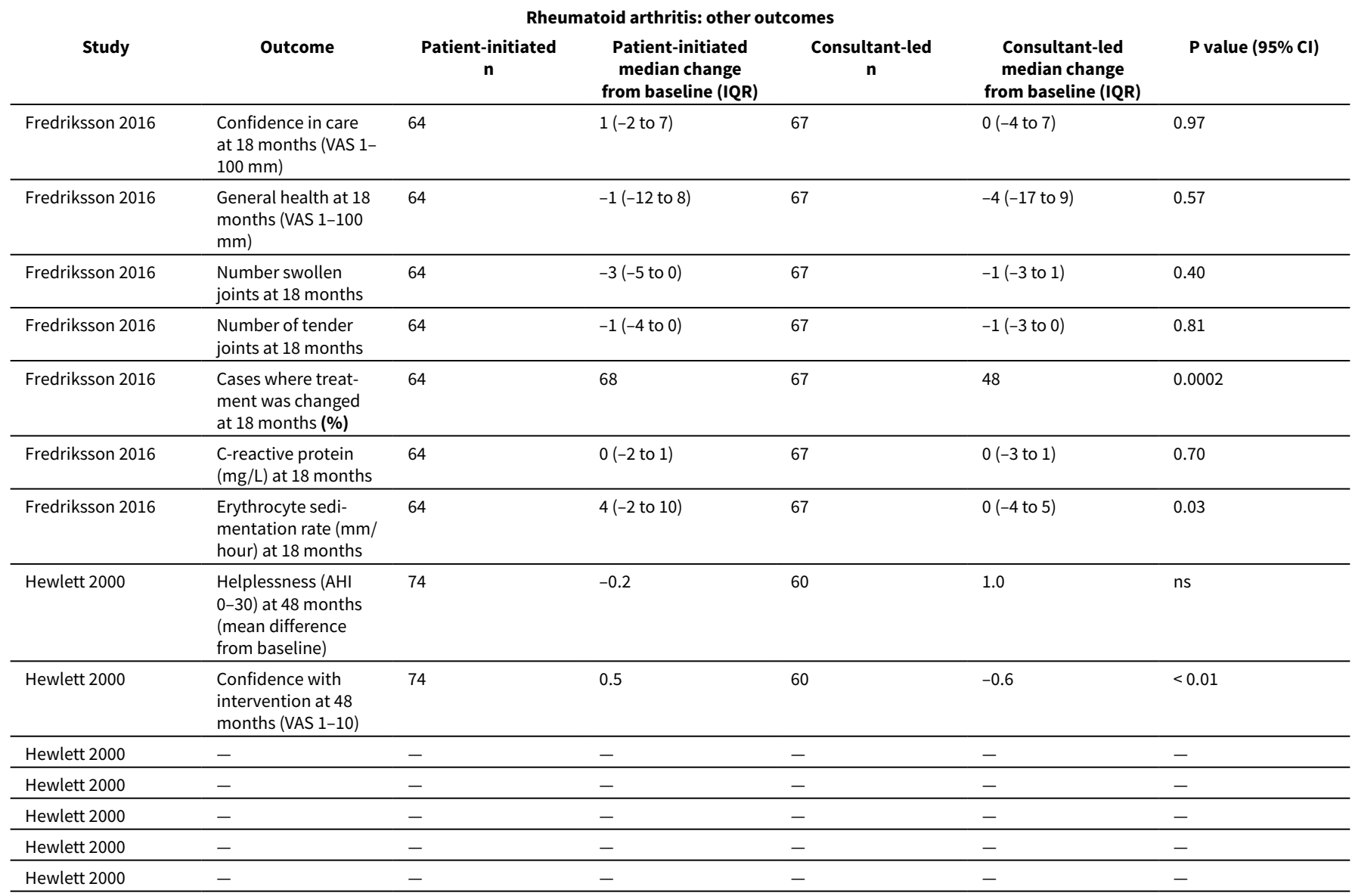

Analysis 1.19. Comparison 1 Patient-initiated appointment systems versus consultant-led appointment systems, Outcome 19 Asthma: other outcomes.

\begin{tabular}{llllll} 
Study & Outcome & $\begin{array}{c}\text { Patient-initiated } \\
\mathbf{n}\end{array}$ & $\begin{array}{c}\text { Asthma: other outcomes } \\
\text { Patient-initiated } \\
\text { mean (SD) }\end{array}$ & $\begin{array}{c}\text { Consultant-led } \\
\mathbf{n}\end{array}$ & $\begin{array}{c}\text { Consultant-led } \\
\text { mean (SD) }\end{array}$ \\
\hline Lahdensuo 1996 & Lung function & 56 & NR & 59 & NR \\
\hline Lahdensuo 1996 & Days off work & 56 & $2.8(0-62)$ & 59 & $\mathrm{~ns}$ \\
\hline
\end{tabular}

\section{AP PEN DICES}

\section{Appendix 1. Search strategies}

Database: Ovid MEDLINE(R) In-Process \& Other Non-Indexed Citations and Ovid MEDLINE $(R)<1946$ to Present>

1 (patient $^{\star}$ adj3 initiate $\left.{ }^{\star}\right) \cdot$ ti,ab.

2 (patient* adj3 led).ti,ab.

3 (patient $^{\star}$ adj3 access $\left.^{\star}\right) \cdot$ ti,ab. 
4 (patient $^{\star}$ adj3 request ${ }^{\star}$ ).ti,ab.

5 self refer ${ }^{\star} . t i, a b$.

6 open access ${ }^{\star} . t i, a b$.

7 direct access ${ }^{\star} . t i, a b$.

8 advanced access ${ }^{\star} . t i, a b$.

9 unscheduled.ti,ab.

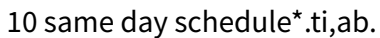

11 shared care.ti,ab.

12 (patient* adj (choice or choosing)).ti,ab.

13 "out of hours".ti,ab.

14 Health Services Accessibility/og [Organization \& Administration]

15 or/1-14

16 exp "Appointments and Schedules"/

17 appointment $^{\star} . t i, a b$.

18 (outpatient* or out patient*).ti,ab.

19 (clinic or clinics).ti,ab.

20 Outpatient Clinics, Hospital/

21 ((follow up ${ }^{\star}$ or followup $\left.{ }^{\star}\right)$ and (visit* or consultation $\left.\left.{ }^{\star}\right)\right)$.ti,ab.

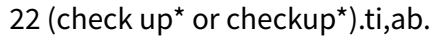

23 secondary care.ti,ab.

24 or/16-23

2515 and 24

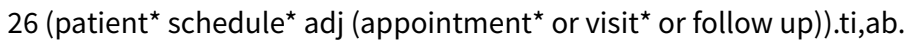

27 (same day adj (appointment* or visit* or schedule*)).ti,ab.

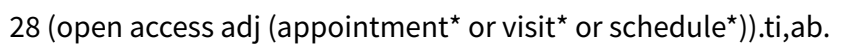

29 (patient adj3 access ${ }^{\star}$ adj3 (follow up ${ }^{\star}$ or visit* or appointment ${ }^{\star}$ )).ti,ab.

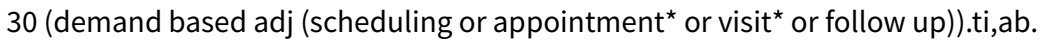

31 advanced access scheduling.ti,ab.

32 (patient initiated adj3 (follow up* or appointment $\left.{ }^{\star}\right)$ ).ti,ab.

33 or $/ 26-32$

3425 or 33

Database: Embase <1974 to Present $>$

1 (patient $^{\star}$ adj3 initiate $\left.{ }^{\star}\right) \cdot$ ti,ab.

2 (patient ${ }^{\star}$ adj3 led).ti,ab.

3 (patient ${ }^{\star}$ adj3 access $\left.{ }^{\star}\right)$.ti,ab.

Patient-initiated appointment systems for adults with chronic conditions in secondary care (Review) 
4 (patient $^{\star}$ adj3 request ${ }^{\star}$ ).ti,ab.

5 self refer ${ }^{\star} . t i, a b$.

6 open access ${ }^{\star} . t i, a b$.

7 direct access ${ }^{\star} . t i, a b$.

8 advanced access ${ }^{\star} . t i, a b$.

9 unscheduled.ti,ab.

10 same day schedule ${ }^{\star} . t i, a b$.

11 shared care.ti,ab.

12 (patient* adj (choice or choosing)).ti,ab.

13 "out of hours".ti,ab.

14 or/1-13

15 appointment*.ti,ab.

16 (outpatient $^{\star}$ or out patient $\left.{ }^{\star}\right) . \mathrm{ti}, \mathrm{ab}$.

17 (clinic or clinics).ti,ab.

18 ((follow up ${ }^{\star}$ or followup $\left.{ }^{\star}\right)$ and (visit* or consultation $\left.\left.{ }^{\star}\right)\right) . t i, a b$.

19 (check up* or checkup $\left.{ }^{\star}\right)$. ti,ab.

20 secondary care.ti,ab.

21 or $/ 15-20$

2214 and 21

23 (patient* schedule $^{\star}$ adj (appointment* or visit $^{\star}$ or follow up)).ti,ab.

24 (same day adj (appointment* or visit* ${ }^{\star}$ or schedule*)).ti,ab.

25 (open access adj (appointment* or visit* or schedule*)).ti,ab.

26 (patient adj3 access $^{\star}$ adj3 (follow up ${ }^{\star}$ or visit* or appointment $\left.^{\star}\right)$ ).ti,ab.

27 (demand based adj (scheduling or appointment ${ }^{\star}$ or visit ${ }^{\star}$ or follow up)).ti,ab.

28 advanced access scheduling.ti,ab.

29 (patient initiated adj3 (follow up* or appointment ${ }^{\star}$ )).ti,ab.

30 or/23-29

3122 or 30

Database: PsycINFO <1806 to Present>

1 (patient $^{\star}$ adj3 initiate $\left.{ }^{\star}\right) \cdot$ ti,ab.

2 (patient ${ }^{\star}$ adj3 led).ti,ab.

3 (patient $^{\star}$ adj3 access $\left.{ }^{\star}\right)$.ti,ab.

4 (patient $^{\star}$ adj3 request $\left.{ }^{\star}\right) \cdot$ ti,ab.

5 self refer ${ }^{\star} . t i, a b$.

6 open access ${ }^{\star} . \mathrm{ti}, \mathrm{ab}$.

Patient-initiated appointment systems for adults with chronic conditions in secondary care (Review) 
7 direct access ${ }^{\star} . \mathrm{ti}, \mathrm{ab}$.

8 advanced access ${ }^{\star} . t i, a b$.

9 unscheduled.ti,ab.

10 same day schedule ${ }^{\star}$.ti,ab.

11 shared care.ti,ab.

12 (patient ${ }^{\star}$ adj (choice or choosing)).ti,ab.

13 "out of hours".ti,ab.

14 or/1-13

15 appointment*.ti,ab.

16 (outpatient ${ }^{\star}$ or out patient ${ }^{\star}$ ).ti,ab.

17 (clinic or clinics).ti,ab.

18 clinics/

19 ((follow up ${ }^{\star}$ or followup $\left.{ }^{\star}\right)$ and (visit* or consultation $\left.\left.{ }^{\star}\right)\right)$. ti,ab.

20 (check up* or checkup $\left.{ }^{\star}\right)$. ti,ab.

21 secondary care.ti,ab.

22 or/15-21

2314 and 22

24 (patient $^{\star}$ schedule $^{\star}$ adj (appointment ${ }^{\star}$ or visit ${ }^{\star}$ or follow up)).ti,ab.

25 (same day adj (appointment* or visit* or schedule*)).ti,ab.

26 (open access adj (appointment ${ }^{\star}$ or visit $^{\star}$ or schedule*)).ti,ab.

27 (patient adj3 access $^{\star}$ adj3 (follow up* or visit* $^{\star}$ or appointment ${ }^{\star}$ )).ti,ab.

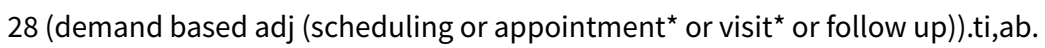

29 advanced access scheduling.ti,ab.

30 (patient initiated adj3 (follow up* or appointment ${ }^{\star}$ )).ti,ab.

31 or/24-30

3223 or 31

CDSR and CENTRAL

\#1 (patient ${ }^{\star}$ near/3 initiate $\left.{ }^{\star}\right): t i, a b$

\#2 (patient* near/3 led):ti,ab

\#3 patient $^{\star}$ near/3 access $\left.^{\star}\right): t i, a b$

\#4 (patient ${ }^{\star}$ near/3 request $\left.{ }^{\star}\right):$ ti,ab

\#5 "self refer*":ti,ab

\#6 "open access":ti,ab

\#7 "direct access"

\#8 "advanced access*":ti,ab 
\#9 unscheduled:ti,ab

\#10 "same day schedule*":ti,ab

\#11 "shared care":ti,ab

\#12 (patient ${ }^{\star}$ next (choice* or choosing)):ti,ab

\#13 "out of hours":ti,ab

\#14 MeSH descriptor: [Health Services Accessibility] this term only

$\# 15 \# 1$ or \#2 or \#3 or \#4 or \#5 or \#6 or \#7 or \#8 or \#9 or \#10 or \#11 or \#12 or \#13 or \#14

\#16 MeSH descriptor: [Appointments and Schedules] explode all trees

\#17 appointment*:ti,ab

\#18 (outpatient* or "out patient"):ti,ab

\#19 (clinic or clinics):ti,ab

\#20 MeSH descriptor: [Outpatient Clinics, Hospital] explode all trees

\#21 (("follow up " or followup*) and (visit* or consultation*)):ti,ab

\#22 ("check up*" or checkup ):ti,ab

\#23 "secondary care":ti,ab

\#24 \#16 or \#17 or \#18 or \#19 or \#20 or \#21 or \#22 or \#23

\#25 \#15 and \#24

\#26 ("patient* schedule*" next (appointment* or visit* or "follow up")):ti,ab

\#27 ("same day" next (appointment* or visit* or schedule*)):ti,ab

\#28 ("open access" next (appointment* or visit* or schedule*)):ti,ab

\#29 ((patient near/3 access $\left.{ }^{\star}\right)$ near/3 ("follow up*" or visit* or appointment $\left.\left.{ }^{\star}\right)\right): t i, a b$

\#30 ("demand based" next (scheduling or appointment* or visit* or "follow up")):ti,ab

\#31 "advanced access scheduling":ti,ab

\#32 ("patient initiated" near/3 ("follow up*" or appointment $\left.{ }^{\star}\right)$ ):ti,ab

\#33 \#26 or \#27 or \#28 or \#29 or \#30 or \#31 or \#32

\#34 \#25 or \#33

HMIC Health Management Information Consortium $<1979$ to Present $>$

1 (patient $^{\star}$ adj3 initiate $\left.{ }^{\star}\right) \cdot$ ti,ab.

2 (patient* adj3 led).ti,ab.

3 (patient $^{\star}$ adj3 access $\left.^{\star}\right) \cdot$ ti,ab.

4 (patient $^{\star}$ adj3 request $\left.{ }^{\star}\right) \cdot$ ti,ab.

5 self refer ${ }^{\star} . t i, a b$.

6 open access ${ }^{\star} . \mathrm{ti}, \mathrm{ab}$.

7 direct access ${ }^{\star} . t i, a b$.

8 advanced access ${ }^{\star} . t i, a b$. 
9 unscheduled.ti,ab.

10 same day schedule ${ }^{\star} . t i, a b$.

11 shared care.ti,ab.

12 (patient ${ }^{\star}$ adj (choice or choosing)).ti,ab.

13 "out of hours".ti,ab.

14 or/1-13

15 appointment ${ }^{\star} . t i, a b$.

16 (outpatient ${ }^{\star}$ or out patient ${ }^{\star}$ ).ti,ab.

17 (clinic or clinics).ti,ab.

18 Outpatient Clinics, Hospital/

19 ((follow up ${ }^{\star}$ or followup $\left.{ }^{\star}\right)$ and (visit* or consultation*)).ti,ab.

20 (check up* or checkup*).ti,ab.

21 secondary care.ti,ab.

22 or $/ 15-21$

23 (patient $^{\star}$ schedule $^{\star}$ adj (appointment ${ }^{\star}$ or visit $^{\star}$ or follow up)).ti,ab.

24 (same day adj (appointment ${ }^{\star}$ or visit* or schedule $\left.{ }^{\star}\right)$ ).ti,ab.

25 (open access adj (appointment ${ }^{\star}$ or visit $^{\star}$ or schedule $\left.{ }^{\star}\right)$ ).ti,ab.

26 (patient adj3 access $^{\star}$ adj3 (follow up* or visit* or appointment ${ }^{\star}$ )).ti,ab.

27 (demand based adj (scheduling or appointment ${ }^{\star}$ or visit* or follow up)).ti,ab.

28 advanced access scheduling.ti,ab.

29 (patient initiated adj3 (follow up* or appointment ${ }^{\star}$ )).ti,ab.

30 or $/ 23-29$

3114 and 22

3230 or 31

CINAHL via EBSCOhost

\begin{tabular}{ll}
\hline S45 & S28 OR S44 \\
\hline S44 & S29 OR S30 OR S31 OR S32 OR S33 OR S34 OR S36 OR S37 OR S40 OR S41 OR S43 \\
\hline S43 & AB ("patient initiated" and (follow*up* or appointment*)) \\
\hline S42 & TI ("patient initiated" and (follow* up* or appointment $\left.\left.{ }^{\star}\right)\right)$ \\
\hline S41 & AB ("advanced access scheduling") \\
\hline S40 & TI ("advanced access scheduling") \\
\hline S39 & AB ("demand based" and (scheduling or appointment* or visit* or follow*up*)) \\
\hline
\end{tabular}

Patient-initiated appointment systems for adults with chronic conditions in secondary care (Review) 


\begin{tabular}{|c|c|}
\hline S38 & TI ("demand based" and (scheduling or appointment ${ }^{\star}$ or visit* or follow*up*)) \\
\hline S37 & AB ("patient* access" ${ }^{\star}$ and (follow* ${ }^{\star} p^{\star}$ or visit $^{\star}$ or appointment $\left.\left.{ }^{\star}\right)\right)$ \\
\hline S36 & $\mathrm{TI}$ (patient ${ }^{\star}$ and access ${ }^{\star}$ and (follow* ${ }^{\star}{ }^{\star}$ or visit $^{\star}$ or appointment $\left.\left.{ }^{\star}\right)\right)$ \\
\hline S35 & $\mathrm{TI}\left(\right.$ patient $^{\star} \mathrm{N} 3$ access $^{\star}$ ) and $\mathrm{TI}\left(\right.$ follow* ${ }^{\star}$ up $^{\star}$ or visit* or appointment $\left.{ }^{\star}\right)$ ) \\
\hline S34 & AB ("open access" AND (appointment* or visit* or schedule*)) \\
\hline S33 & TI ("open access" AND (appointment* or visit* or schedule*)) \\
\hline S32 & AB ("same day" and (appointment* or visit* or schedule*)) \\
\hline S31 & TI ("same day" and (appointment* or visit* or schedule*)) \\
\hline S30 & AB ("patient schedule*" AND (appointment* or visit* or follow*up)) \\
\hline S29 & TI ("patient schedule*" AND (appointment* or visit* or follow*up)) \\
\hline S28 & S17 AND S27 \\
\hline S27 & S18 OR S19 OR S20 OR S21 OR S22 OR S23 OR S24 OR S25 OR S26 \\
\hline S26 & TI secondary care OR AB secondary care \\
\hline S25 & TI ( checkup* or "check up*" ) OR AB ( checkup* or "check up*" ) \\
\hline S24 & AB ( "follow up *" or followup*) AND AB ( visit* or consultation*) \\
\hline S23 & TI ( "follow up*" or followup*) AND TI ( visit* or consultation* ) \\
\hline S22 & (MM "Outpatient Service/AM/OG/UT") \\
\hline S21 & TI ( clinic or clinics) OR AB ( clinic or clinics ) \\
\hline S20 & TI ( outpatient" or "out patient" ) OR AB ( outpatient* or "out patient" \\
\hline S19 & TI appointment* OR AB appointment ${ }^{\star}$ \\
\hline S18 & (MM "Appointments and Schedules") \\
\hline S17 & $\begin{array}{l}\text { S1 OR S2 OR S3 OR S4 OR S5 OR S6 OR S7 OR S8 OR S9 OR S10 OR S11 OR S12 OR S13 OR S14 OR } \\
\text { S15 OR S16 }\end{array}$ \\
\hline S16 & (MM "Health Services Accessibility/AM/EV/UT") \\
\hline S15 & (MM "Direct Access") \\
\hline S14 & TI "out of hours" OR AB "out of hours" \\
\hline S13 & TI "patient* choosing ${ }^{\star}$ " OR AB "patient* choosing*" \\
\hline $\mathrm{S} 12$ & TI "patient* choice" ${ }^{\star}$ OR AB "patient* choice ${ }^{\star "}$ \\
\hline S11 & TI "shared care" OR AB "shared care" \\
\hline
\end{tabular}


(Continued)
S10
TI "same day schedule*" OR AB "same day schedule*"

\section{S9}

S8

S7

S6

$$
\text { S5 }
$$

S4

S3

$\mathrm{S} 2$

S2

$\mathrm{S} 1$
TI unscheduled OR AB unscheduled

TI advanced access ${ }^{*}$ OR AB advanced access ${ }^{*}$

TI open access ${ }^{\star}$ OR AB open access*

TI self refer* OR AB self refer ${ }^{\star}$

TI patient ${ }^{\star}$ N3 request* OR AB patient ${ }^{\star}$ N3 request ${ }^{\star}$

TI patient ${ }^{\star}$ N3 access ${ }^{\star}$ OR AB patient ${ }^{\star}$ N3 access ${ }^{\star}$

TI patient* N3 led OR AB patient* N3 led

TI patient ${ }^{\star}$ N3 initiate* OR AB patient* N3 initiate ${ }^{\star}$

ProQuest Dissertations \& Theses Global

(ti,ab("patient* schedul*" NEAR/4 (appointment* OR visit* OR "follow up*")) OR ti,ab("same day" NEAR/4 (appointment* OR visit* OR schedule*)) OR ti,ab("open access" NEAR/4 (appointment* OR visit* OR schedule*)) OR ti,ab(patient* NEAR/3 access* NEAR/3 (appointment* OR visit* OR "follow up*")) OR ti,ab("demand based" NEAR/4 (scheduling OR appointment* OR visit* OR "follow up*")) OR ti,ab("advanced access scheduling") OR ti,ab("patient initiated" NEAR/3 ("follow up*" OR appointment*))) OR ((ti,ab(patient* NEAR/3 initiate*) OR ti,ab(patient* NEAR/3 led*) OR ti,ab(patient* NEAR/3 access*) OR ti,ab(patient* NEAR/3 requested) OR ti,ab("self refer*") OR ti,ab("open access*") OR ti,ab("direct access*") OR ti,ab("advanced access*") OR ti,ab(unscheduled) OR ti,ab("shared care") OR (ti,ab(patient* NEAR/4 choice) OR ti,ab(patient* NEAR/4 choosing)) OR ti,ab("out of hours")) AND (ti,ab(appointment*) OR ti,ab(outpatient* OR "out patient*") OR ti,ab(clinic OR clinics) OR (ti,ab("follow up*" OR followup*) AND ti,ab(visit* OR consultation*)) OR ti,ab("check up*" OR checkup*) OR ti,ab("secondary care")))

ClinicalTrials.gov

"patient initiated" or Open access appointments or "Open access" and clinics or "open access"

International Clinical Trials Registry Platform (ICTRP)

Patient initiated or open access

\section{Appendix 2. Data extraction form}

\section{Bibliographic details}

First author:

Title:

Year:

Citation: 


\section{STUDY}

Country:

Setting:

Recruitment dates:

Study design (e.g. RT, cluster-RCT):

Main aim of study:

Funding source:

Notes:

\section{PARTICIPANTS}

Health condition

Inclusion criteria

\section{Exclusion criteria}

Notes:

\section{INTERVENTION}

\begin{tabular}{ll}
\hline Telephone contact: Yes No & Safety net review: Yes No \\
\hline Describe: & Describe: \\
\hline Any other health professional involvement? & Other/notes:- \\
Yes No & \\
\hline Describe: & \\
\hline
\end{tabular}

\section{CONTROL}

\section{Consultant led: Yes No}

Nurse led: Yes No
Appointment schedule:

Emergency appointments available: Yes No unclear

Other-describe:

OUTCOMES (PRIMARY) please list and add more rows if needed

\begin{tabular}{lll}
\hline OUTCOME MEASURE/TOOL FOLLOW-UP & FOL
\end{tabular}


OUTCOMES (SECONDARY) please list and add more rows if needed

\begin{tabular}{lll}
\hline OUTCOME MEASURE FOLLW-UP & FOW
\end{tabular}

ANALYSIS

Describe (ITT, per protocol, clustering):

\section{RESULTS IF RANDOMISED (Cluster, controlled)}

\section{INTERVENTION}

\section{CONTROL}

\section{Sig/Effect Size/Cl etc}

No. eligible

No. randomised

No. lost to follow-up

Age (mean SD)

Male/Female

Outcome (e.g. mean (SD) and effect size with $\mathrm{Cl}$, P values)

\section{RISK OF BIAS (low risk, high risk, unclear)}

\section{Random sequence generation}


(Continued)

Notes:

\section{Allocation concealment}

Notes :

\section{Blinding of participants and personnel}

Notes:

\section{Blinding of outcome assessment}

Notes:

\section{Incomplete outcome data}

Notes:

\section{Selective reporting}

Notes:

Data extracted by:

Date:

Checked by:

Date:

\section{Appendix 3. GRADE summary table}

Author(s):

Date:

Question: Patient initiated appointment systems compared to consultant-led appointments for managing care for people with chronic conditions in secondary care

Setting: secondary care (hospital outpatient care)

Bibliography: 


\begin{tabular}{|c|c|c|c|c|c|c|c|c|c|c|c|}
\hline \multicolumn{6}{|l|}{ Certainty assessment } & \multicolumn{2}{|c|}{ № of patients } & \multicolumn{2}{|l|}{ Effect } & \multirow[t]{2}{*}{ Certainty } & \\
\hline $\begin{array}{l}\text { № Study design } \\
\text { of } \\
\text { stud- } \\
\text { ies }\end{array}$ & $\begin{array}{l}\text { Risk of } \\
\text { bias }\end{array}$ & $\begin{array}{l}\text { Inconsis- } \\
\text { tency }\end{array}$ & $\begin{array}{l}\text { Indirect- } \\
\text { ness }\end{array}$ & $\begin{array}{l}\text { Impreci- } \\
\text { sion }\end{array}$ & $\begin{array}{l}\text { Oth- } \\
\text { er } \\
\text { con- } \\
\text { sid- } \\
\text { era- } \\
\text { tions }\end{array}$ & $\begin{array}{l}\text { Pa- } \\
\text { tient-ini- } \\
\text { tiat- } \\
\text { ed ap- } \\
\text { point- } \\
\text { ment } \\
\text { sys- } \\
\text { tems }\end{array}$ & $\begin{array}{l}\text { con- } \\
\text { sul- } \\
\text { tant } \\
\text {-led } \\
\text { ap- } \\
\text { point- } \\
\text { ments }\end{array}$ & $\begin{array}{l}\text { Relative } \\
(95 \% \mathrm{CI})\end{array}$ & $\begin{array}{l}\text { Absolute } \\
(95 \% \mathrm{CI})\end{array}$ & & \\
\hline \multicolumn{12}{|l|}{ Anxiety (HADS) } \\
\hline 5 Randomised trials & Seriousa & $\begin{array}{l}\text { Not seri- } \\
\text { ous }\end{array}$ & Not serious & Serious $b$ & None & -10 & - & $\begin{array}{l}\text { OR } 0.87 \\
(0.68 \text { to } \\
1.12)\end{array}$ & $\begin{array}{l}1 \text { fewer per } 1000 \\
\text { (from } 1 \text { fewer to } 1 \text { fewer) }\end{array}$ & $\begin{array}{l}\oplus \oplus \ominus \ominus \\
\text { Low }\end{array}$ & - \\
\hline \multicolumn{12}{|l|}{ Depression (HADS) } \\
\hline 6 Randomised trials & Seriousa & $\begin{array}{l}\text { Not seri- } \\
\text { ous }\end{array}$ & Not serious & Serious $b$ & None & -10 & -10 & $\begin{array}{l}\text { OR } 0.79 \\
(0.51 \text { to } \\
1.23)\end{array}$ & $\begin{array}{l}1 \text { fewer per } 1000 \\
\text { (from } 1 \text { fewer to } 1 \text { fewer) }\end{array}$ & $\begin{array}{l}\oplus \oplus \ominus \ominus \\
\text { Low }\end{array}$ & - \\
\hline \multicolumn{12}{|l|}{ Quality of life } \\
\hline 7 Randomised trials & Serious & $\begin{array}{l}\text { Not seri- } \\
\text { ous }\end{array}$ & Not serious & Seriousc & None & 707 & 779 & - & $\begin{array}{l}\text { SMD } 0.12 \text { higher } \\
\text { ( } 0.01 \text { lower to } 0.24 \text { higher) }\end{array}$ & $\oplus \oplus \ominus \odot$ Low & - \\
\hline \multicolumn{12}{|c|}{ Service utilisation (contacts) } \\
\hline 15 Randomised trials & Serious ${ }^{a}$ & $\begin{array}{l}\text { Not seri- } \\
\text { ous }\end{array}$ & Serious $d$ & $\begin{array}{l}\text { Not seri- } \\
\text { ous }\end{array}$ & None & - & - & - & $\begin{array}{l}\mathbf{0} \\
(0 \text { to } 0)\end{array}$ & $\begin{array}{l}\oplus \oplus \ominus \ominus \\
\text { Low }\end{array}$ & - \\
\hline \multicolumn{12}{|c|}{ Service utilisation (costs) } \\
\hline 8 Randomised trials & Serious ${ }^{a}$ & Seriouse & Not serious & Serious d,e & None & - & - & - & $\begin{array}{l}\mathbf{0} \\
(0 \text { to } 0)\end{array}$ & $\begin{array}{l}\oplus \ominus \ominus \ominus \\
\text { Very low }\end{array}$ & - \\
\hline \multicolumn{12}{|l|}{ Patient satisfaction } \\
\hline 12 Randomised trials & Seriousa & Serious ${ }^{f}$ & Not serious & $\begin{array}{l}\text { not seri- } \\
\text { ous }\end{array}$ & None & - & - & - & $\begin{array}{l}\mathbf{0} \\
(0 \text { to } 0)\end{array}$ & $\begin{array}{l}\oplus \oplus \oplus \ominus \\
\text { Low }\end{array}$ & - \\
\hline
\end{tabular}




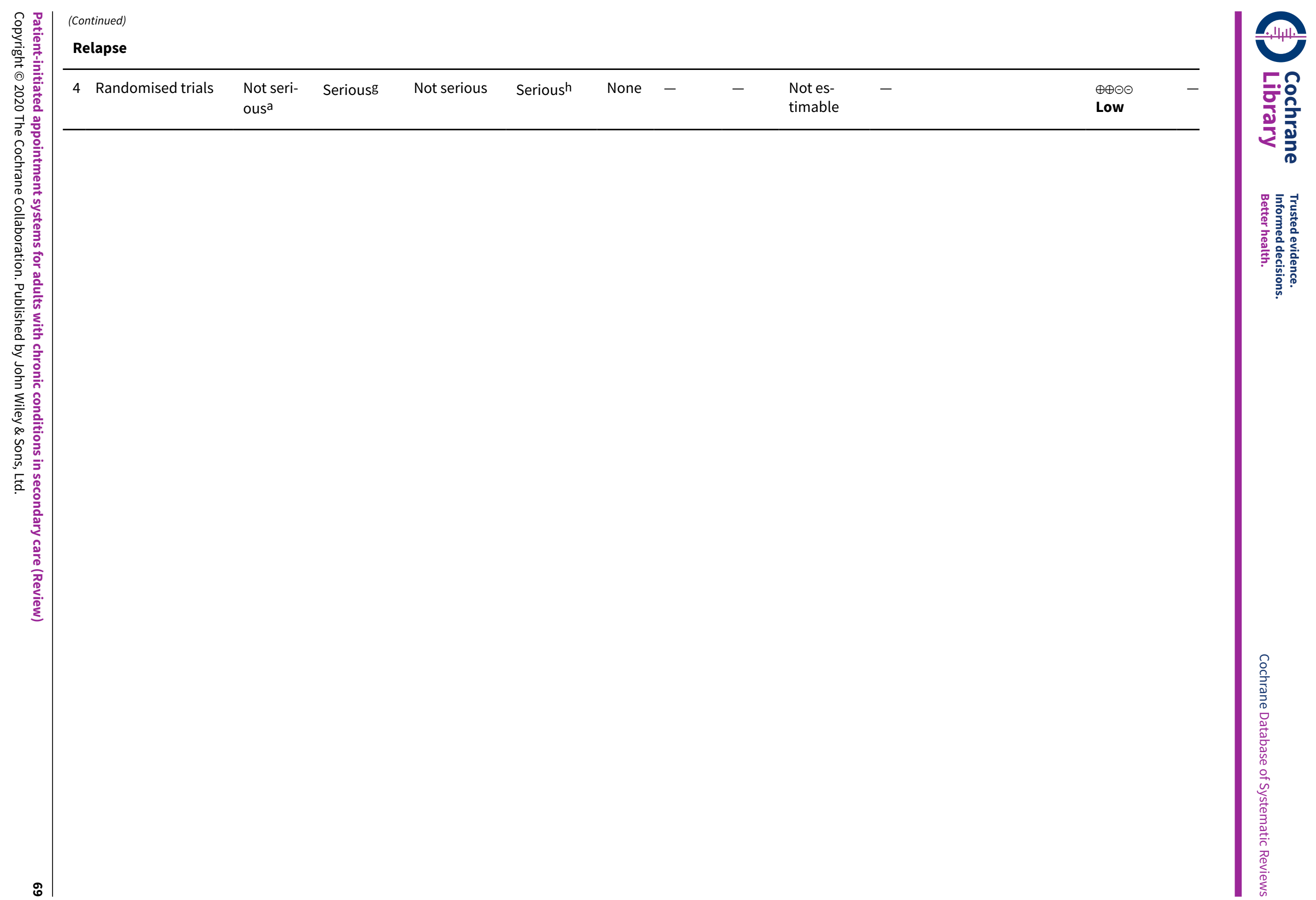


CI: confidence interval; HADS: Hospital Anxiety and Depression Scale; OR: odds ratio; SMD: standardised mean difference.

\section{Explanations}

aRisk of bias reporting is largely unclear.

bWide confidence intervals for all studies.

CSMD point is quite variable and some with wide confidence intervals.

dContact with different services reported differently.

eWide ranging costs of services reported but partly due to wide range of contacts reported.

fSatisfaction was reported differently across studies.

gRelapse considered and reported differently across conditions.

hVery few studies reported relapse.

\section{CONTRIBUTIONS OF AUTHORS}

RW: conceiving, designing and co-ordinating protocol; screening search results and retrieved papers against eligibility criteria; appraising quality of papers and data extraction; analysis and interpretation of data; data management and writing up final review.

JTC: conceiving, designing and co-ordinating protocol; informing search strategies; screening search results and retrieved papers against eligibility criteria; appraising quality of papers; extracting data; analysis and interpretation of data; providing comments on final review.

MR: designing protocol; led design of search strategies and literature search; helped with document retrieval; writing and editing parts of final review.

RA: editing protocol; screening search results and retrieved papers against eligibility criteria; appraising quality of papers; extracting data; data management; editing final review.

LA: screening search results; checking retrieved papers against eligibility criteria; appraising quality of papers; extracting data; data management; checking data inputting in Review Manager 5.

OU: designing statistical methods of the protocol; analysis and interpretation of final review from a methodological perspective; editing final review.

JM: analysis and interpretation of final review; editing final review.

VG: screening search results; checking retrieved papers against eligibility criteria; appraising quality of papers; editing final review.

SB: screening search results; retrieved papers from update search against eligibility criteria; appraising quality of papers; extracting data as necessary; editing final review.

MP: conceiving and designing protocol; determining search strategies; interpreting data from a clinical and policy perspective; involved in writing final review.

KS: conceiving, designing and co-ordinating protocol; interpretation of data in final review; providing a methodological and policy perspective within writing up and giving advice on review; securing funding for review.

\section{DECLARATIONS OF INTEREST}

RW: has been involved in a related review that has been published.

JTC: has been involved in a related review that has been published.

MR: has been involved in a related review that has been published.

RA: none.

LA: none.

OU: none.

JM: none.

VG: implemented a patient-initiated appointment system for people with rheumatoid arthritis at Plymouth Healthcare NHS Trust which has been published.

SB: none. 
MP: implemented a patient-initiated appointment system for people with rheumatoid arthritis at Plymouth Healthcare NHS Trust which has been published. Has been involved in a related review that has been published.

KS: has been involved in a related review that has been published.

\section{SOURCES OF SUPPORT}

\section{Internal sources}

- No sources of support supplied

\section{External sources}

- National Institute of Health Research, UK.

This systematic review will be funded by the National Institute for Health Research (NIHR) through Peninsula CLAHRC. This review will present independent research commissioned by the NIHR. The views expressed in this publication are those of the author(s) and not necessarily those of the National Health Service, the NIHR or the Department of Health.

\section{DIFFERENCES BETWEEN PROTOCOL AND REVIEW}

Simon Briscoe, Lindsey Anderson, Vicki Goodwin and Justin Matthews were added to the review after registration of the protocol (Whear 2013). Their contributions are detailed in Contributions of authors.

Service utilisation (contacts) and resource use as described in the protocol have been relabelled for consistency as service utilisation (contacts and costs).

We conducted two outcome analyses using a fixed-effect model rather than a random-effects model as the two studies and the outcomes included in these analyses were so similar, making the fixed-effect model more appropriate.

We had planned to present the risk ratios of any dichotomous data, but were unable to do so due to the data being mixed dichotomous and continuous data.

For the meta-analyses, we used the most common/nearest reported time point across studies to combine data.

We did not assess reporting bias due to the low numbers of studies in the meta-analyses.

We only conducted a subgroup analysis by health condition for the outcomes that had three or more studies with useable data (anxiety, depression and quality of life). We were unable to conduct a subgroup analysis based on age.

The studies did not report clinician satisfaction. The review authors decided not to include this outcome as a separate row in the 'Summary of findings' table (contrary to the protocol), but have included it in the comments. 